pÿ士-Amino diphenyl phosphonates as novel inhibitors of Escherichia coli ClpP protease

\title{
Moreno-Cinos, Carlos
}

2019-01-24

Moreno-Cinos , C , Sassetti , E, Salado , I G , Witt , G, Benramdane , S , Reinhardt , L , Cruz , C D , Joossens , J , Van der Veken , P , Brötz-Oesterhelt , H, Tammela , P S M , pÿWinterhalter , M , Gribbon , P , Windshügel , B \& Augustyns , K 2019 , ' \pm -Amino diphenyl phosphonates as novel inhibitors of Escherichia coli ClpP protease ' , Journal of Medicinal Chemistry, vol. 62 , no. 2 , pp. 774-797 . https://doi.org/10.1021/acs.jmedchem.8b01466

http://hdl.handle.net/10138/308651

https://doi.org/10.1021/acs.jmedchem.8b01466

acceptedVersion

Downloaded from Helda, University of Helsinki institutional repository.

This is an electronic reprint of the original article.

This reprint may differ from the original in pagination and typographic detail.

Please cite the original version. 
2 Carlos Moreno-Cinos, ${ }^{1, \S}$ Elisa Sassetti, ${ }^{2,5,}$ Irene G. Salado, ${ }^{1}$ Gesa Witt, ${ }^{2}$ Siham Benramdane, ${ }^{1}$ Laura

3 Reinhardt, ${ }^{3}$ Cristina Durante Cruz, ${ }^{4}$ Jurgen Joossens, ${ }^{1}$ Pieter Van der Veken, ${ }^{1}$ Heike Brötz-Oesterhelt, ${ }^{3}$

4 Päivi Tammela, ${ }^{4}$ Mathias Winterhalter, ${ }^{5}$ Philip Gribbon, ${ }^{2}$ Björn Windshügel, ${ }^{2, *}$ and Koen Augustyns ${ }^{1, *}$.

$5{ }^{1}$ Laboratory of Medicinal Chemistry, University of Antwerp, Universiteitsplein 1, B-2610 Antwerp,

6 Belgium.

72 Fraunhofer Institute for Molecular Biology and Applied Ecology, ScreeningPort,

8 Schnackenburgallee 114, 22525, Hamburg, Germany.

$9{ }^{3}$ Interfaculty Institute for Microbiology and Infection Medicine, University of Tübingen, Auf der 10 Morgenstelle 28, 72076, Tübingen, Germany.

$11{ }^{4}$ Drug Research Program, Division of Pharmaceutical Biosciences, University of Helsinki, Viikinkaari 5E, FI-00014 Helsinki, Finland.

${ }^{5}$ Department of Life Sciences and Chemistry, Jacobs University Bremen gGmbH, Campus Ring 1, 28759 Bremen, Germany.

$\S$ Shared first author.

* Shared corresponding author.

\section{ABSTRACT}

Increased Gram-negative bacteria resistance to antibiotics is becoming a global problem and new classes of antibiotics with novel mechanisms of action are required. The caseinolytic protease subunit $\mathrm{P}(\mathrm{ClpP})$ is a serine protease conserved among bacteria that is considered as an interesting drug target. ClpP function is involved in protein turnover and homeostasis, stress-response and virulence among other processes. The focus of this study was to identify new inhibitors of Escherichia coli ClpP and to understand their mode of action. A focused library of serine protease inhibitors based on diaryl phosphonate warheads was tested for ClpP inhibition and a chemical exploration around the hit compounds was conducted. Altogether 14 new potent inhibitors of E. coli ClpP were identified. 
and, respectively, to its moderate but consistent antibacterial properties as well as the favorable cytotoxicity profile.

\section{INTRODUCTION}

Antibiotic resistance is a major global problem in both developed and developing countries. ${ }^{1}$ The selection pressures on microorganisms when in contact with antibacterial agents underlies the emergence of resistance, ${ }^{2}$ and the efficacy of first and second line antibiotics is decreasing at an alarming rate. ${ }^{3}$ The importance of antimicrobial drug discovery was underlined by the World Health Organization's (WHO) first global report on antibiotic resistance which attributed 25,000 deaths in Europe and 2 million worldwide per year to bacterial infections. ${ }^{4}$ Of particular concern are Gramnegative multidrug-resistant bacteria (MDR) which are becoming more prevalent. ${ }^{5}$ Among the antibiotic drugs launched since the year 2000, only five new classes were introduced and only one was directed against Gram-negative bacteria in combination with $\beta$-lactams. ${ }^{6}$ To avoid key resistance mechanisms to pre-existing antibiotics, drug discovery research has focussed on addressing alternative targets with novel mechanisms of antibacterial action. ${ }^{7}$

The antibacterial drug target caseinolytic protease proteolytic subunit (ClpP) is a widely conserved protein which is present in bacteria, in many eukaryotes (including humans, localised in mitochondria), but is absent in archaea and mollicutes.$^{8-9} \mathrm{ClpP}$, a chymotrypsin-like serine protease,${ }^{10}$ is thought to play an important role in determining virulence and stress response by modulating virulence factor expression in several bacteria including Staphylococcus aureus, Listeria monocytogenes and Streptococcus pneumoniae. ${ }^{11-14} \mathrm{ClpP}$ degrades mistranslated, misfolded or aggregated proteins, arising as a result of stress factors (e.g. heat stress and antibiotics). ${ }^{8}$ In Listeria monocytogenes $\mathrm{ClpP}$ was found to be essential for bacterial survival in macrophages. ${ }^{12}$ In Streptococcus pneumoniae the levels of ClpP were demonstrated to be correlated with nitric oxide stress. ${ }^{14-15}$

ClpP proteases in Gram-positive bacteria have been more thoroughly studied as drug targets, but also advances in Gram-negative ClpPs were recently reported. Robinson et al. ${ }^{16}$ identified ClpP as potential target for antivirulence therapies by showing differences between growth curves of wild-type and $c l p P$ defective $E$. coli under nitric oxide stress conditions. It has also been demonstrated that in $E$. coli is 
1 responsible for the cleavage of proteins involved in metabolism, transcription factors, as well as in

2 oxidative stress response and starvation. ${ }^{17}$ Furthermore, $c l p P$-deficient Legionella pneumophila showed

3 impaired virulence and reduced translocation of effector proteins in the studies from Zhao et al. ${ }^{18}$ and

$4 \mathrm{ClpX}$ and $\mathrm{ClpP} 2$ were identified by Qiu et al. ${ }^{19}$ as part of the proteolytic network of the

5 exopolysaccharide alginate biosynthesis in Pseudomonas aeruginosa, a marker for the onset of chronic

$6 \quad$ lung infection in cystic fibrosis.

$7 \mathrm{ClpP}$ is a tetradecamer with a cylindrical shape. The 14 subunits are arranged in two heptameric rings

8 and a central chamber which contains the active sites of each subunit. ${ }^{8}$ Each active site comprises the

9 canonical Ser-His-Asp catalytic triad (for most bacteria). ${ }^{20}$ The peptidase activity, a characteristic of a chymotrypsin-like serine protease, ${ }^{21}$ typically results in peptides of 7-8 residues length, ${ }^{22}$ with cuts occurring after non-polar residues. ${ }^{23} \mathrm{ClpP}$ proteolytic activity requires the presence of specific ATPases (ClpX and ClpA in the case of E. coli) $)^{23}$ of the AAA+ enzyme superfamily, whose function is to recognize, unfold and then transfer the substrates into the chamber, thus forming the Clp complex together with $\mathrm{ClpP} .{ }^{24}$ The interface between $\mathrm{ClpP}$ and the $\mathrm{AAA}+$ partners has been investigated as a drug targeting site and several antibacterial peptides were identified, which activate and deregulate ClpP. ${ }^{24-25}$ These acyldepsipeptides (ADEPs) prevent ATPases binding to the heptameric rings of ClpP, resulting in uncontrolled proteolysis of essential bacterial proteins and eventually in bacterial cell death. ${ }^{8,26}$

A promising approach to target the virulence-related functions of $\mathrm{ClpP}$ is to develop enzyme inhibitors used in combination with existing antibiotics. The pioneering efforts of Böttcher and Sieber to target ClpP led to the development of a series of $\beta$-lactone inhibitors (among them D3, Figure 1) for S. aureus ClpP. ${ }^{27}$ These inhibitors bind covalently to the catalytic serine, leading to irreversible inhibition of proteolytic activity. Further characterization proved their ability to reduce bacterial virulence expression not only in S. aureus but also in L. monocytogenes. ${ }^{28-29}$ The potency of this inhibitor was improved 3to 5-fold with the optimized $\beta$-lactone U1 (Figure 1) ${ }^{30}$ However, the reduced plasma stability of these compounds, due to the fast hydrolysis of the cyclic ester, impeded further clinical development. ${ }^{31}$ 
1 Thereafter, a new class of potent ClpP inhibitors with better plasma stability was discovered by the

2 Sieber group. ${ }^{31}$ The phenyl esters (AV170, Figure 1) irreversibly inhibited S. aureus ClpP, and 3 triggered deoligomerization of the ClpP tetradecamer into inactive heptamers. Their higher potency, $4 \quad$ inhibition kinetics and plasma lifetime, compared to the $\beta$-lactone series, were countered by their lower 5 anti-virulence activity. Furthermore, attempts to further improve their acyl-enzyme complex stability 6 unfortunately let to a loss of ClpP reactivity. ${ }^{31} \mathrm{~A}$ non-covalent inhibitor against $S$. aureus $\mathrm{ClpP}$ has been 7 also identified in a high-throughput screening (HTS) campaign. ${ }^{32}$ The inhibitor (AV145, Figure 1) bound to the handle region near the active site, locking S. aureus ClpP in a novel and inactive conformation. However, binding of ClpX to ClpP revoked the inhibitory effect of AV145 and its analogues in bacteria. ${ }^{32}$

Boron derived compounds have also shown evidence of successfully inhibiting ClpP in Mycobacterium tuberculosis as demonstrated for bortezomib by Moreira et al. or the substrate-based peptide boronate inhibitors by Akopian et al. (Figure 1). ${ }^{33,34}$ Nevertheless, proteasome inhibition, short half-life, poor pharmacokinetics and its high cost limited the direct use of bortezomib, the most potent in cellulo of previously described compounds at $M$. tuberculosis treatment. ${ }^{33}$

Recently, also pyrimidines have been shown to inhibit ClpP. ${ }^{35}$ Compounds (P33, Figure 1) targeting Plasmodium falciparum $\mathrm{ClpP}$ achieved inhibition of growth and segregation of the apicoplast during the cell cycle, leading to parasite death. Although ClpPs have been investigated in several organisms, inhibition of Gram-negative bacteria ClpP remains untapped and the chloromethyl ketone (Z-LY-CMK, Figure 1) co-crystallized by Szyk and Maurizi was the only reported inhibitor for E. coli ClpP reported so far. ${ }^{36}$ 


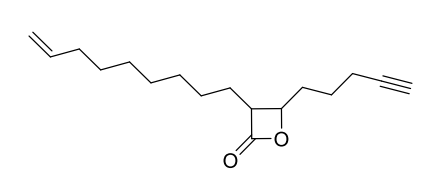

$\beta$-lactone D3

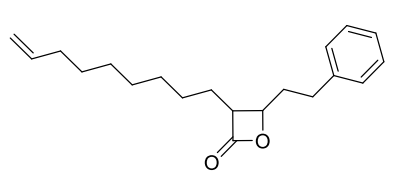

$\beta$-lactone U1

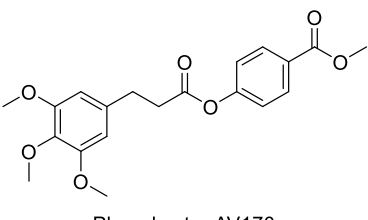

Phenyl ester AV170

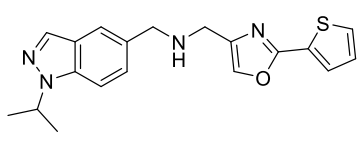

AV145

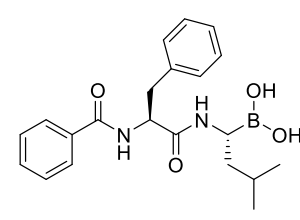

Bortezomib

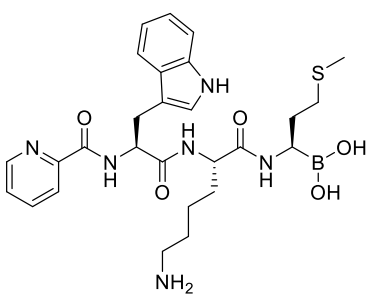

$N$-(Picolinoyl)-Trp-Lys-boroMet

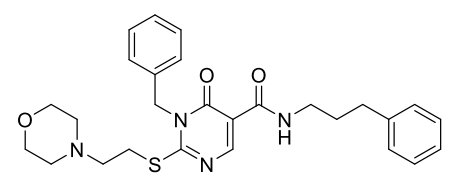

Pyrimidine 33

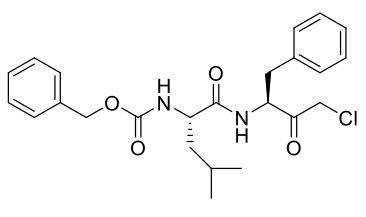

Z-LY-CMK

2 Figure 1. Examples of ClpP reported inhibitors.

3

4 Despite the demonstration of the potential of irreversible inhibitors on different ClpPs, inhibitors with

5 a classical $\alpha$-amino diaryl phosphonate warhead remained unexplored. ${ }^{37}$ Thus far, several diaryl

6 phosphonate compounds have been identified as potent, irreversible serine protease inhibitors. Some

7 illustrative examples are a urokinase plasminogen activator (uPA) inhibitor reported by Joossens et

8 al. ${ }^{38-39}$ a dipeptidyl peptidase 8 (DPP8) inhibitor by Van der Veken et al., ${ }^{40}$ an elastase inhibitor by

9 Winiarski et al., ${ }^{41}$ a subtilisin inhibitor by Pietrusewicz et al.,${ }^{42}$ and the GluC and SplA inhibitors by

10 Burchacka et al. ${ }^{43-44}$

11 The mode of action for this class of inhibitors (Figure 2) involves a nucleophilic attack by the hydroxyl of the active site serine on the electrophilic phosphorus atom, leading to the formation of a phosphonate ester. The initial enzyme-inhibitor complex is unstable. Therefore, hydrolysis of the aryl ester (with a 

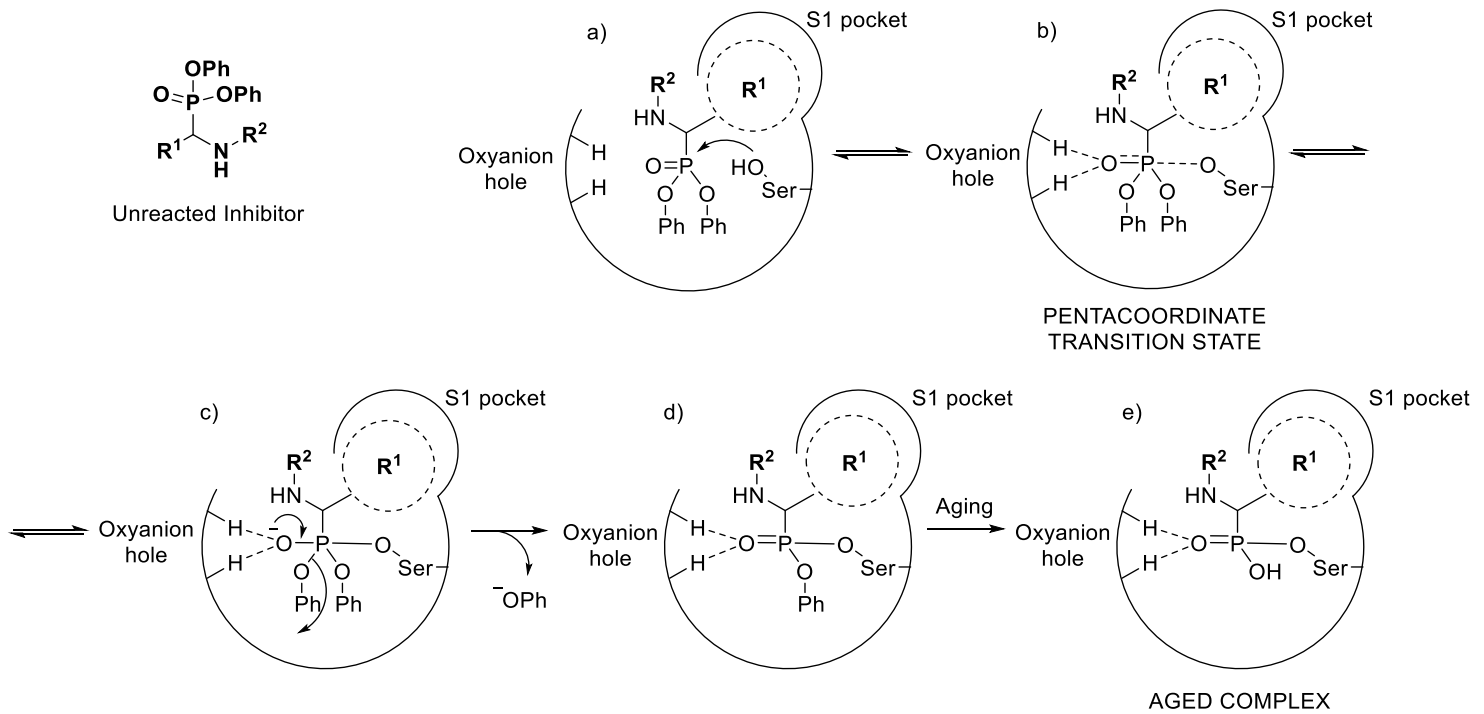

1

2 Figure 2. Binding mechanism of diphenyl phosphonates with serine proteases. a) The unreacted inhibitor enters the active site, with the $\mathrm{R}^{1}$ moiety filling the $\mathrm{S} 1$ pocket while the phosphonate sits at a reachable distance from the oxyanion hole and the catalytic serine. b) Nucleophilic attack of the serine to the phosphonate facilitated by the hydrogen bonds of this group with the oxyanion hole residues to form the pentacoordinate transition state. c) Formalised bonds between the serine oxygen and phosphorus of the phosphonate lead to a negative charge on the oxygen that, when recovering the tetrahedral geometry, leads to the release of the phenol group. d) Stabilised configuration after covalent bonding between ligand and serine protease. e) Slow hydrolysis of the remaining phenolate leads to formation of the aged complex.

The aim of this work was to identify new classes of compounds as inhibitors of ClpP activity and investigate their mechanisms of action. We describe a series of $\alpha$-amino diphenyl phosphonate esters as the first potent inhibitors of $E$. coli ClpP, using this species as a model organism for Gram-negative bacteria, encouraged by the availability of a crystal structure and by the previous studies where a clpPdefective strain showed a decreased growth under nitric oxide stress conditions. ${ }^{16,36}$

\section{RESULTS}

Chemical explorations and enzymatic activity screening. The existing diarylphosphonate library of the Medicinal Chemistry group of the University of Antwerp (UAMC) was highly enriched in hydrophilic and polar residues in $\mathrm{R}^{1}$ position, since it was mainly focused on targeting trypsin-like 
serine proteases. Based on the specificity of chymotrypsin-like serine proteases for lipophilic residues in the $\mathrm{S} 1$ pocket, a library of hydrophobic moieties in $\mathrm{R}^{1}$ was designed. Some analogues of the previously described inhibitors (Z-LY-CMK and Lys-boroMet in Figure 1) were also included, together with variations on the warhead (diversity of arylphosphonates and nitriles)..$^{34,36}$ Synthesis of the analogues with -Cbz in $\mathrm{R}^{2}$ position and a diphenyl phosphonate as warhead (10-23) was carried out following the general synthesis described in Scheme 1, where protection of the hydroxyl groups on some of the aromatic rings was carried out in order to improve the yield of the following steps: Dess-Martin oxidation ${ }^{45}$ and a modified alternative of the Birum-Oleksyszyn reaction previously reported by Van der Veken et al. ${ }^{46}$ Those protected compounds, were finally debenzylated following the conditions of Okano et al. ${ }^{47}$

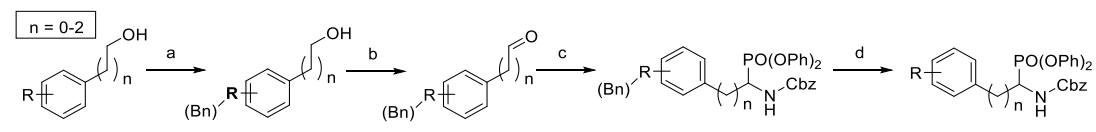

Scheme 1. Reagents and conditions. a) $\mathrm{K}_{2} \mathrm{CO}_{3}$, BnBr, DMF, rt, 4 h. b) Dess-Martin periodinane, DCM, 0-25 ${ }^{\circ} \mathrm{C}, 2$ h. c) $\mathrm{CbzNH}_{2}, \mathrm{P}(\mathrm{OPh})_{3}, \mathrm{Cu}(\mathrm{OTf})_{2}, \mathrm{DCM}, \mathrm{rt}, 16$ h. d) Pentamethylbenzene, $\mathrm{BCl}_{3}, \mathrm{DCM}$, $-78^{\circ} \mathrm{C}, 15 \min$.

Synthesis of the compounds with modifications on the phosphonate warhead or its substitution by a nitrile (23-30) were undertaken as described in Scheme 2, while dipeptidic diphenyl phosphonates (3241) were obtained by prior cleavage of -Cbz and subsequent peptidic coupling. These protocols can be found in the experimental section.

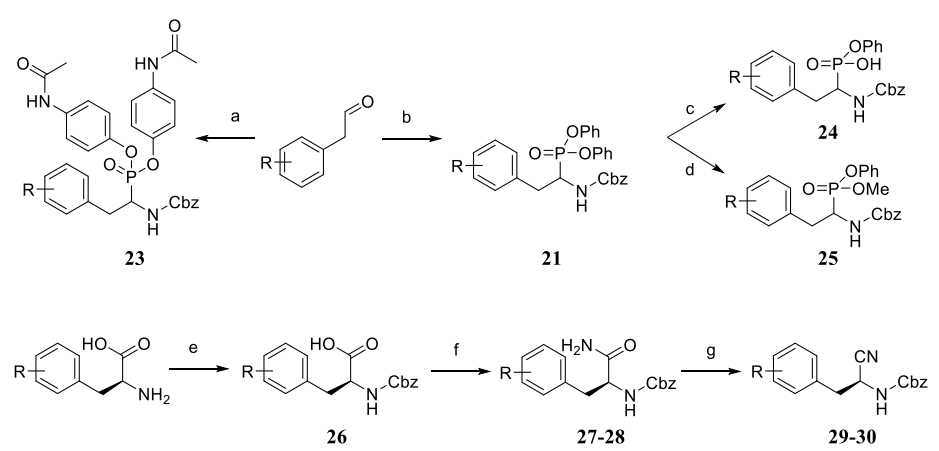

Scheme 2. Reagents and conditions. a) $\mathrm{CbzNH}_{2}$, tris(4-acetamidophenyl) phosphite, $\mathrm{Cu}(\mathrm{OTf})_{2}, \mathrm{DCM}$, rt, 16 h. b) $\mathrm{CbzNH}_{2}, \mathrm{P}(\mathrm{OPh})_{3}, \mathrm{Cu}(\mathrm{OTf})_{2}, \mathrm{DCM}, \mathrm{rt}, 16$ h. c) $\mathrm{KOH}, \mathrm{H}_{2} \mathrm{O}$ :dioxane (1:1), rt, 16 h. d) $\mathrm{NH}_{3}$, 
$1 \mathrm{NH}_{4} \mathrm{Cl}, \mathrm{MeOH}, \mathrm{rt}, 72$ h. e) $\mathrm{CbzCl}, \mathrm{NaOH}, \mathrm{H}_{2} \mathrm{O}, 0-25{ }^{\circ} \mathrm{C}, 2$ h. f) Isobutylchloroformate, $N-$

2 methylmorpholine, $\left.\mathrm{NH}_{3}, \mathrm{DCM}, 0-25^{\circ} \mathrm{C}, 16 \mathrm{~h} . \mathrm{g}\right)$ Burgess reagent, $\mathrm{DCM}, \mathrm{rt}, 16 \mathrm{~h}$.

3 The compounds 10-41 were evaluated for ClpP inhibition together with a subset of diaryl

4 phosphonates from the UAMC library (42-74), selected in order to expand the variety of $\mathrm{R}^{1}$

5 and $\mathrm{R}^{2}$ residues (Table 1). ClpP inhibition was assessed by a high-throughput screen in 384-

6 well format using a fluorescence assay with Suc-LY-AMC as fluorogenic substrate. The

7 compounds were screened at $200 \mu \mathrm{M}$ concentration. Compounds were considered as active if

8 the percentage of inhibition (compared to a control without compounds) was higher or equal

9 to $75 \%$ (or $\leq 25 \%$ remaining activity).

$$
\mathrm{R}_{\mathrm{H}^{1}}^{\mathrm{WH}} \mathrm{R}^{2}
$$

11 Figure 3. Generic compound structure.

Table 1. Enzymatic inhibition of the apolar exploration and first library screening.

\begin{tabular}{|c|c|c|c|c|c|}
\hline \multirow{2}{*}{ Compd. } & \multirow{2}{*}{$\mathbf{R}^{1}$} & \multirow{2}{*}{$\mathbf{R}^{2}$} & \multirow{2}{*}{ Warhead } & \multicolumn{2}{|c|}{ E. coli ClpP inhibition } \\
\hline & & & & $\% \mathrm{I}(200 \mu \mathrm{M})$ & $\mathrm{IC}_{50}(\mu \mathrm{M})$ \\
\hline Z-LY-CMK & & & & 100 & 14.4 \\
\hline 10 & & $-\mathrm{Cbz}$ & $-\mathrm{PO}(\mathrm{OPh})_{2}$ & 7 & ND \\
\hline 11 & & $-\mathrm{Cbz}$ & $-\mathrm{PO}(\mathrm{OPh})_{2}$ & 7 & ND \\
\hline 12 & & $-\mathrm{Cbz}$ & $-\mathrm{PO}(\mathrm{OPh})_{2}$ & 6 & ND \\
\hline 13 & & $-\mathrm{Cbz}$ & $-\mathrm{PO}(\mathrm{OPh})_{2}$ & 6 & ND \\
\hline 14 & & $-\mathrm{Cbz}$ & $-\mathrm{PO}(\mathrm{OPh})_{2}$ & $<1$ & ND \\
\hline 15 & & $-\mathrm{Cbz}$ & $-\mathrm{PO}(\mathrm{OPh})_{2}$ & 13 & ND \\
\hline
\end{tabular}


16

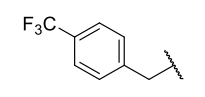

17

18

21

22

23

24

25

29

30

32

36
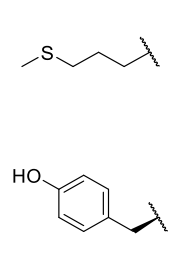

41
$-\mathrm{Cbz}$

$-\mathrm{Cbz}$

$-\mathrm{Cbz}$

$-\mathrm{Cbz}$

$-\mathrm{Cbz}$

$-\mathrm{Cbz}$

$-\mathrm{Cbz}$

$-\mathrm{Cbz}$

$-\mathrm{Cbz}$

$-\mathrm{Cbz}$

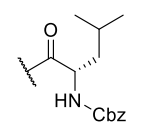

$\underbrace{\mathrm{O}}_{\mathrm{HN}_{\mathrm{Cbz}}} \mathrm{NH}_{\mathrm{NH}_{2}}$

$-\mathrm{PO}(\mathrm{OPh})_{2}$

$-\mathrm{CN}$

$-\mathrm{PO}(\mathrm{OPh})_{2}$

$-\mathrm{PO}(\mathrm{OPh})_{2}$

$-\mathrm{PO}(\mathrm{OPh})_{2}$

$$
\stackrel{\mathrm{IO}}{\mathrm{O}=\mathrm{POH}}
$$

O=poph

$-\mathrm{CN}$

$-\mathrm{CN}$

$-\mathrm{PO}(\mathrm{OPh})_{2}$
100

$14.2 \pm 1.3$

ND

3

ND

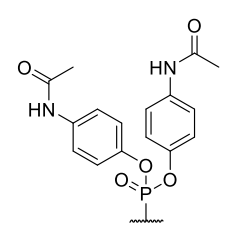

9

ND

11

ND

14

ND

$<1$

ND

$<1$

ND

$<1$

ND

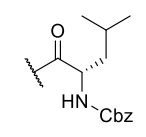

42
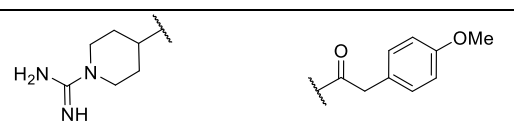

$-\mathrm{PO}(\mathrm{OPh})_{2}$

13

4

ND

43
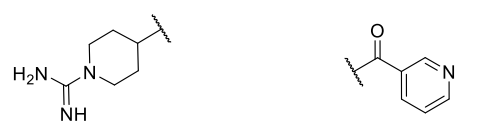

$-\mathrm{PO}(\mathrm{OPh})_{2}$

13

ND

44<smiles>CCC1CCC(C)C(N)C1</smiles><smiles>CCC(=O)C1CCCC1</smiles>

$-\mathrm{PO}(\mathrm{OPh})_{2}$ 24

ND

45
$-\mathrm{PO}(\mathrm{OPh})_{2}$
ND

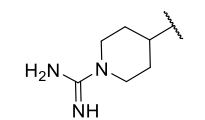<smiles>CC(C)(C)C=CC1=CC=CC1</smiles> 


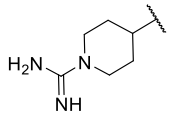<smiles>CC(C)(C)OCCOc1ccccc1</smiles>

$-\mathrm{PO}(\mathrm{OPh})_{2}$

47<smiles>CCC1CCC(N)CC1</smiles><smiles></smiles>

$-\mathrm{PO}(\mathrm{OPh})_{2}$

6

ND

48<smiles>CC1CCC(N(C)N)CC1</smiles><smiles>CC(C)=CCc1ccc2c(c1)OCO2</smiles>

$-\mathrm{PO}(\mathrm{OPh})_{2}$

ND

49<smiles>CC1CCN(N)CC1</smiles><smiles>CC(=O)C=C1C=CC2=COCC21</smiles>

$-\mathrm{PO}(\mathrm{OPh})_{2}$ 24

ND

50<smiles>CCC1CCC(N)CC1</smiles><smiles></smiles>

$-\mathrm{PO}(\mathrm{OPh})_{2}$

51

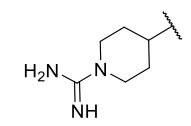<smiles>CC1CCC2CCCC(CC2)O1</smiles>

$-\mathrm{PO}(\mathrm{OPh})_{2}$

ND

52

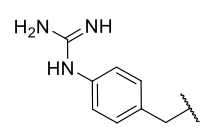

紧

$-\mathrm{PO}(\mathrm{OPh})_{2}$

ND

53
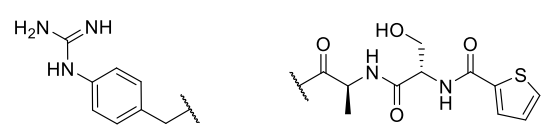

$-\mathrm{PO}(\mathrm{OPh})_{2}$

$49.5 \pm 0.5$

54

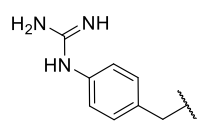

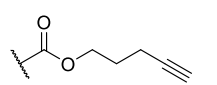

$-\mathrm{PO}(\mathrm{OPh})_{2}$

23

ND

55<smiles>CCCc1ccc(NC(=N)N)cc1</smiles><smiles>CCC(=O)CCOCCN</smiles>

56<smiles>CCCc1ccc(NC(=N)N)cc1</smiles><smiles>CC(=O)COC1=C(F)C(F)C(F)(F)C1(F)F</smiles>

57<smiles>CCCc1ccc(NC(=N)N)cc1</smiles>

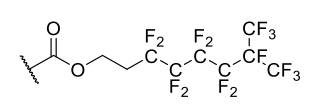

$-\mathrm{PO}(\mathrm{OPh})_{2}$

58

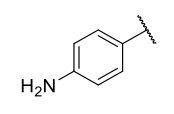

$$
-\mathrm{Cbz}
$$

$-\mathrm{PO}(\mathrm{OPh})_{2}$

96

$39.8 \pm 2.9$

59

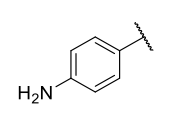

等

$-\mathrm{PO}(\mathrm{OPh})_{2}$

1

ND

60

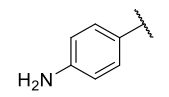

$\stackrel{0}{1} \sim \mathrm{CF}_{3}$

$-\mathrm{PO}(\mathrm{OPh})_{2}$

$<1$

ND 

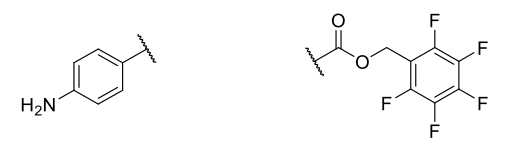

$-\mathrm{PO}(\mathrm{OPh})_{2}$

62
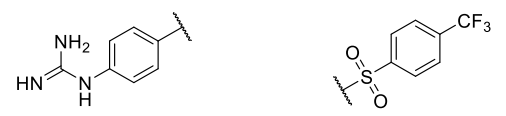

$-\mathrm{PO}(\mathrm{OPh})_{2}$

27

ND

63
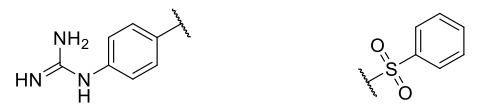

$-\mathrm{PO}(\mathrm{OPh})_{2}$

29

ND

64
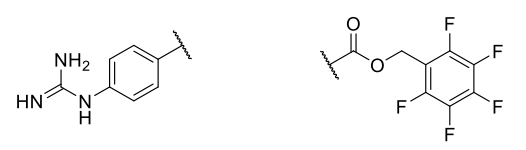

$-\mathrm{PO}(\mathrm{OPh})_{2}$

ND

65

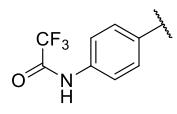

싱

$-\mathrm{PO}(\mathrm{OPh})_{2}$

64

ND

66

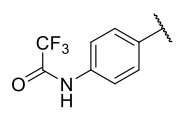

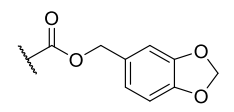

$-\mathrm{PO}(\mathrm{OPh})_{2}$

93

$8.2 \pm 0.8$

67

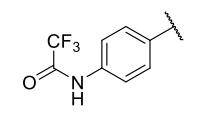

监 $\sim_{\mathrm{NH}_{2}}$

$-\mathrm{PO}(\mathrm{OPh})_{2}$

ND

68<smiles>CCc1ccc(NC(=O)NC(C)C)cc1</smiles>

$-\mathrm{Cbz}$

$-\mathrm{PO}(\mathrm{OPh})_{2}$

9

ND

69<smiles>Cc1ccc(OCCN)cc1</smiles>

$-\mathrm{Cbz}$

$-\mathrm{PO}(\mathrm{OPh})_{2}$

ND

70

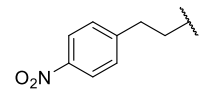

$-\mathrm{Cbz}$

$-\mathrm{PO}(\mathrm{OPh})_{2}$

100

$13.1 \pm 1.2$

71

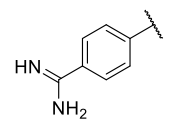

싱

$-\mathrm{PO}(\mathrm{OPh})_{2}$

93

$48.1 \pm 1.7$

72

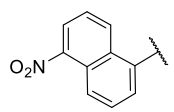

싱-

$-\mathrm{PO}(\mathrm{OPh})_{2}$

17

ND

73

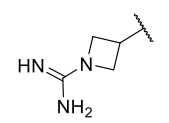

舟

$-\mathrm{PO}(\mathrm{OPh})_{2}$

12

ND

74

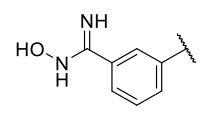

散

$-\mathrm{PO}(\mathrm{OPh})_{2}$

23

ND

75

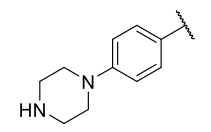

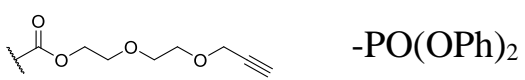

25

ND 
1 Six compounds emerged as active in the primary screen $(\mathbf{1 6}, \mathbf{5 3}, \mathbf{5 8}, \mathbf{6 6}, \mathbf{7 0}$ and $\mathbf{7 1})$. Dose-response

2 experiments confirmed all initial hits and the $\mathrm{IC}_{50}$ values ranged between 8.2 and $49.5 \mu \mathrm{M}$ (Table 1).

3 The biochemical tests revealed that the S1 pocket showed a preference for hydrophilic moieties, while

$4 \quad \mathbf{1 6}$ represents the only active compound with a lipophilic $\mathrm{R}^{1}$ moiety. Regarding the $\mathrm{R}^{2}$ substitution, a

5 variety of simple carbamates were tolerated, -Cbz being the most common and chemically accessible.

6 However, methyl carbamates and benzodioxol carbamates were also taken into account for future

7 investigations.

8 After learning that the S1 pocket accepted a wider range of side chains, every remaining compound

9 from the library with - $\mathrm{Cbz}$ in $\mathrm{R}^{2}$ position (76-95) was submitted to a second round of experimental 10 testing (Table 2).

Table 2. Enzymatic inhibition of second library screening.

\begin{tabular}{|c|c|c|c|c|c|}
\hline \multirow{2}{*}{ Compd. } & \multirow{2}{*}{$\mathbf{R}^{1}$} & \multirow{2}{*}{$\mathbf{R}^{2}$} & \multirow{2}{*}{ Warhead } & \multicolumn{2}{|c|}{ E. coli ClpP inhibition } \\
\hline & & & & $\% \mathrm{I}(200 \mu \mathrm{M})$ & $\mathrm{IC}_{50}(\mu \mathrm{M})$ \\
\hline 76 & $\mathrm{HN}_{\mathrm{N}}$ & $-\mathrm{Cbz}$ & $-\mathrm{PO}(\mathrm{OPh})_{2}$ & 15 & ND \\
\hline 77 & & $-\mathrm{Cbz}$ & $-\mathrm{PO}(\mathrm{OPh})_{2}$ & 6 & ND \\
\hline 78 & & $-\mathrm{Cbz}$ & $-\mathrm{PO}(\mathrm{OPh})_{2}$ & 100 & $0.6 \pm 0.1$ \\
\hline 79 & & $-\mathrm{Cbz}$ & $-\mathrm{PO}(\mathrm{OPh})_{2}$ & 27 & ND \\
\hline 80 & & $-\mathrm{Cbz}$ & $-\mathrm{PO}(\mathrm{OPh})_{2}$ & 6 & ND \\
\hline 81 & & $-\mathrm{Cbz}$ & $-\mathrm{PO}(\mathrm{OPh})_{2}$ & 3 & ND \\
\hline 82 & & $-\mathrm{Cbz}$ & $-\mathrm{PO}(\mathrm{OPh})_{2}$ & 4 & ND \\
\hline 83 & & $-\mathrm{Cbz}$ & $\mathrm{PO}(\mathrm{OPh})_{2}$ & 29 & ND \\
\hline 84 & & $-\mathrm{Cbz}$ & $-\mathrm{PO}(\mathrm{OPh})_{2}$ & 4 & ND \\
\hline 85 & & $-\mathrm{Cbz}$ & $-\mathrm{PO}(\mathrm{OPh})_{2}$ & 100 & $0.5 \pm 0.0$ \\
\hline
\end{tabular}


86<smiles></smiles>

87<smiles>CCC1CC(Cl)C=CC1[N+]=O</smiles>

$-\mathrm{Cbz}$

$-\mathrm{Cbz}$

$-\mathrm{Cbz}$

$-\mathrm{Cbz}$

$-\mathrm{Cbz}$

$-\mathrm{Cbz}$

$-\mathrm{Cbz}$

$-\mathrm{Cbz}$

$-\mathrm{Cbz}$

95
$-\mathrm{PO}(\mathrm{OPh})_{2}$

$-\mathrm{PO}(\mathrm{OPh})_{2}$

$-\mathrm{PO}(\mathrm{OPh})_{2}$

$-\mathrm{PO}(\mathrm{OPh})_{2}$

$-\mathrm{PO}(\mathrm{OPh})_{2}$

$-\mathrm{PO}(\mathrm{OPh})_{2}$

$-\mathrm{PO}(\mathrm{OPh})_{2}$

$\mathrm{PO}(\mathrm{OPh})_{2}$

$-\mathrm{PO}(\mathrm{OPh})_{2}$

$-\mathrm{PO}(\mathrm{OPh})_{2}$
100

$38.0 \pm 2.4$

ND

ND

88

$100.5 \pm 8.0$

81

$79.7 \pm 7.2$

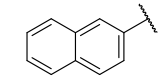

1

2 The biochemical tests resulted in the identification of six additional ClpP inhibitors $\mathbf{( 7 8 , ~ 8 5 , ~ 8 6 , ~ 8 9 , 9 0}$

3 and 92), of which three inhibited the enzyme with a sub-micromolar $\mathrm{IC}_{50}$ value. From this and the

4 previous screening, we concluded that hydrophilicity in the S1 pocket is preferred, and we therefore

5 continued with a chemical exploration of polar groups in $\mathrm{R}^{1}$ together with further modifications around

$6 \quad$ three selected $\mathrm{R}^{1}$ residues.

7 First, based on the polarity of the most active compounds identified so far, the scope of hydrophilic

8 moieties for $\mathrm{R}^{1}$ was enlarged, leaving the rest of the structure unchanged (96-127). Some of these

9 compounds (96-98) were directly obtained from the commercial aldehydes after a Birum-Oleksyszyn 


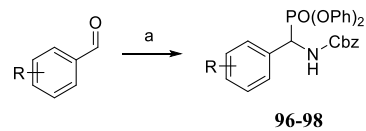

2 Scheme 3. Reagents and conditions. a) $\mathrm{CbzNH}_{2}, \mathrm{P}(\mathrm{OPh})_{3}, \mathrm{Cu}(\mathrm{OTf})_{2}, \mathrm{DCM}, \mathrm{rt}, 16 \mathrm{~h}$.

3 Still, most of them required a higher synthetic effort. The remaining compounds can be summarized in two synthetic schemes. For the first group (107-116), the Birum-Oleksyszyn reaction was conducted on

5 the selected commercial aldehydes with Boc-protected amine, with the subsequent deprotection and 6 guanylation for $\mathbf{1 1 5}$ and $\mathbf{1 1 6}$. This group comprises a variety of aniline and piperidine related moieties 7 in the $R^{1}$ position (Scheme 4).

8

9 Scheme 4. Reagents and conditions. a) $\mathrm{CbzNH}_{2}, \mathrm{P}(\mathrm{OPh})_{3}, \mathrm{Cu}(\mathrm{OTf})_{2}, \mathrm{DCM}, \mathrm{rt}, 16$ h. b) TFA, DCM, rt, 1 h. c) $N, N^{\prime}$-bis-Boc-1-guanylpyrazole, $\mathrm{Et}_{3} \mathrm{~N}, \mathrm{DCM}, \mathrm{rt}, 48 \mathrm{~h}$.

For a second group of aniline-related compounds and aromatic guanidines (117-127), the starting materials were a variety of commercial nitroaryl aldehydes that, after a Birum-Oleksyszyn reaction, were reduced and subsequently substituted in some cases to generate methyl sulphoxyamines, guanydines, dimethylarylureas and methyl amides (Scheme 5). The biochemical tests for ClpP inhibition of these compounds revealed two inhibitors with $\mathrm{IC}_{50}$ values of 0.6 and 71.3 , respectively 


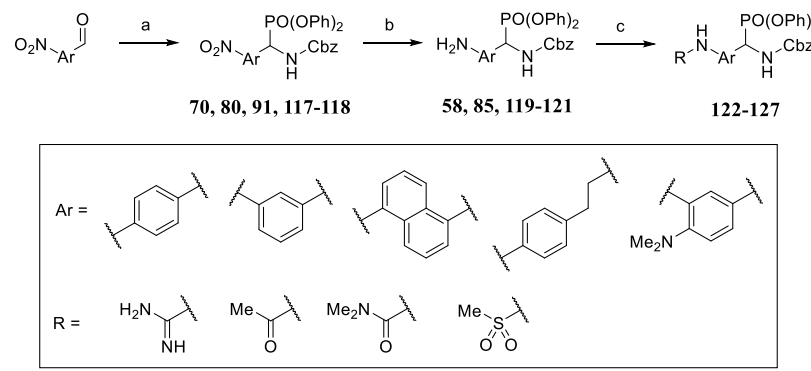

Scheme 5. Reagents and conditions. a) $\mathrm{CbzNH}_{2}, \mathrm{P}(\mathrm{OPh})_{3}, \mathrm{Cu}(\mathrm{OTf})_{2}$, DCM, rt, 16 h. b) $\mathrm{Zn}$, THF: $\mathrm{NH}_{4} \mathrm{Cl}$ (sat. sol.) (1:1), $0{ }^{\circ} \mathrm{C}, 1$ h. c) 124-125: $N, N^{\prime}$-bis-Boc-1-guanylpyrazole, Et $3 \mathrm{~N}, \mathrm{DCM}, \mathrm{rt}, 48 \mathrm{~h}$, then TFA, DCM, rt, 1 h; 122-123, 126-127: RCl, DIPEA, DCM, rt, 2 h.

Finally, further investigation around the two most potent $\mathrm{R}^{1}$ moieties (aniline $\mathbf{8 5}$ and amidine $\mathbf{9 2}$ ) and the only lipophilic structure with activity (4-(trifluoromethyl)benzyl 16) was undertaken, with substitution of the -Cbz by other active substituents from the first screening, together with some warhead alternatives (paracetamol-like phosphonates and nitriles). The chemistry regarding this exploration can be found in Scheme 6 and Scheme 7. None of the 10 tested compounds revealed any pronounced ClpP inhibition (Table 4). A summary of all the compounds initial screening is reported in Figure S1 in the supporting information.
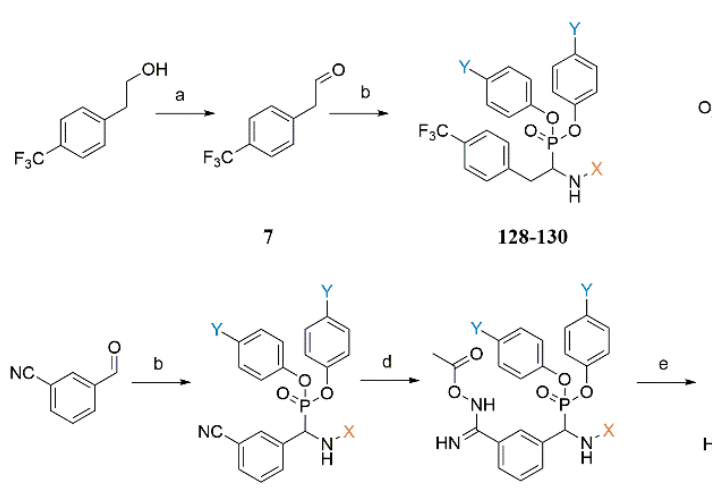

139-141

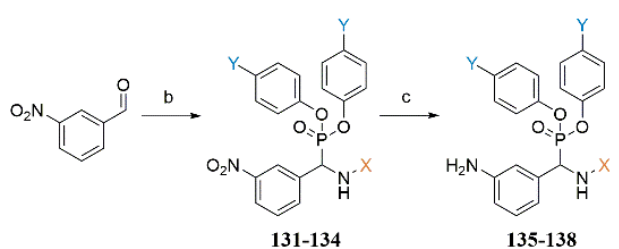

131-134 135-138

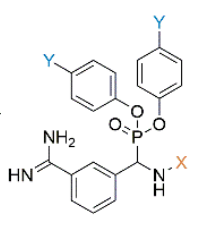

$145-147$

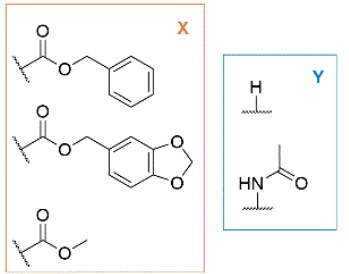

Scheme 6. Reagents and conditions. a) Dess-Martin periodinane, DCM, $0-25^{\circ} \mathrm{C}, 2$ h. b) $\mathrm{CbzNH}_{2}(\mathbf{1 2 9}$, 133, 140)/methyl carbamate $(128,130-132,134,139,141) /$ benzo $[d][1,3]$ dioxol-5-ylmethyl carbamate (132), $\mathrm{P}(\mathrm{OPh})_{3}(\mathbf{1 2 8}, \mathbf{1 3 1 - 1 3 2}, \mathbf{1 3 9}) /$ tris $(4$-acetamidophenyl) phosphite $(\mathbf{1 2 9 - 1 3 0 , 1 3 3 - 1 3 4 , 1 4 0 - 1 4 1 )}$ $\mathrm{Cu}(\mathrm{OTf})_{2}$, DCM, rt, 16 h. c) Zn, THF: $\mathrm{NH}_{4} \mathrm{Cl}$ (aq. sat. sol.) (2:1), 0-25 ${ }^{\circ} \mathrm{C}, 16$ h. d) $\mathrm{NH}_{2} \mathrm{OH} \cdot \mathrm{HCl}$, DIPEA, $\mathrm{EtOH}, 95^{\circ} \mathrm{C}, 30-72 \mathrm{~h}$, then acetic anhydride, $\mathrm{MeCN}$, rt, $1 \mathrm{~h}$; e) $\mathrm{Pd}(\mathrm{II}) / \mathrm{C} 10 \%, \mathrm{H}_{2}$ gas, $\mathrm{AcOH}, \mathrm{rt}, 30 \mathrm{~h}$. 


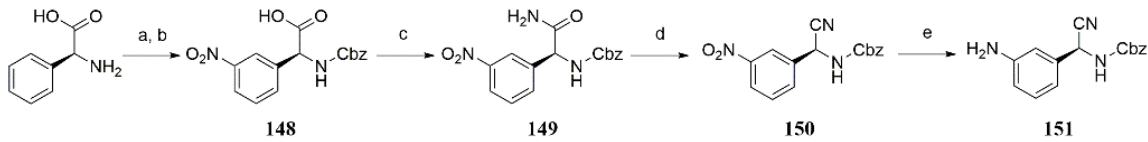

2 Scheme 7. Reagents and conditions. a) $\mathrm{HNO}_{3}, \mathrm{H}_{2} \mathrm{SO}_{4}$, rt, 2 h. b) $\mathrm{CbzCl}, \mathrm{NaOH}, \mathrm{H}_{2} \mathrm{O}, 0-25^{\circ} \mathrm{C}, 2$ h. c)

3 Isobutylchloroformate, $\mathrm{N}$-methylmorpholine, $\mathrm{NH}_{3}, \mathrm{DCM}, 0-25^{\circ} \mathrm{C}, 16$ h. d) Burgess reagent, $\mathrm{DCM}$, rt, $4 \quad 16$ h. e) $\mathrm{Zn}, \mathrm{THF}: \mathrm{NH}_{4} \mathrm{Cl}$ (aq. sat. sol.) $(2: 1), 0-25{ }^{\circ} \mathrm{C}, 16 \mathrm{~h}$.

5 Table 3. Enzymatic inhibition of the hydrophilic exploration.

\begin{tabular}{|c|c|c|c|c|c|}
\hline \multirow{2}{*}{ Compd. } & \multirow{2}{*}{$\mathbf{R}^{1}$} & \multirow{2}{*}{$\mathbf{R}^{2}$} & \multirow{2}{*}{ Warhead } & \multicolumn{2}{|c|}{ E. coli ClpP inhibition } \\
\hline & & & & $\% \mathrm{I}(200 \mu \mathrm{M})$ & $\mathrm{IC}_{50}(\mu \mathrm{M})$ \\
\hline 96 & & $-\mathrm{Cbz}$ & $-\mathrm{PO}(\mathrm{OPh})_{2}$ & 15 & ND \\
\hline 97 & & $-\mathrm{Cbz}$ & $-\mathrm{PO}(\mathrm{OPh})_{2}$ & $<1$ & ND \\
\hline 98 & & $-\mathrm{Cbz}$ & $-\mathrm{PO}(\mathrm{OPh})_{2}$ & 15 & ND \\
\hline 107 & & $-\mathrm{Cbz}$ & $-\mathrm{PO}(\mathrm{OPh})_{2}$ & 100 & $0.6 \pm 0.0$ \\
\hline 108 & & $-\mathrm{Cbz}$ & $-\mathrm{PO}(\mathrm{OPh})_{2}$ & 10 & ND \\
\hline 109 & & $-\mathrm{Cbz}$ & $-\mathrm{PO}(\mathrm{OPh})_{2}$ & 30 & ND \\
\hline 110 & & $-\mathrm{Cbz}$ & $\mathrm{PO}(\mathrm{OPh})_{2}$ & 16 & ND \\
\hline 111 & & $-\mathrm{Cbz}$ & $-\mathrm{PO}(\mathrm{OPh})_{2}$ & 15 & ND \\
\hline 114 & & $-\mathrm{Cbz}$ & $-\mathrm{PO}(\mathrm{OPh})_{2}$ & $<1$ & ND \\
\hline 115 & & $-\mathrm{Cbz}$ & $-\mathrm{PO}(\mathrm{OPh})_{2}$ & 100 & $71.3 \pm 2.4$ \\
\hline 116 & & $-\mathrm{Cbz}$ & $-\mathrm{PO}(\mathrm{OPh})_{2}$ & 18 & ND \\
\hline
\end{tabular}


117

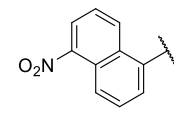

$-\mathrm{Cbz}$

$-\mathrm{PO}(\mathrm{OPh})_{2}$

49

ND

118

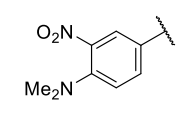

$-\mathrm{Cbz}$

$-\mathrm{PO}(\mathrm{OPh})_{2}$

39

ND

120<smiles>CCCc1ccc(N)cc1</smiles>

$-\mathrm{Cbz}$

$-\mathrm{PO}(\mathrm{OPh})_{2}$

13

ND

121

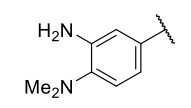

$-\mathrm{Cbz}$

$\mathrm{PO}(\mathrm{OPh})_{2}$

22

ND

122<smiles>CCc1ccc(NC(C)CC)cc1</smiles>

$-\mathrm{Cbz}$

$-\mathrm{PO}(\mathrm{OPh})_{2}$

8

ND

123

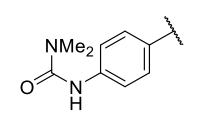

$-\mathrm{Cbz}$

$-\mathrm{PO}(\mathrm{OPh})_{2}$

22

ND

124

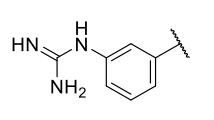

$-\mathrm{Cbz}$

$-\mathrm{PO}(\mathrm{OPh})_{2}$

15

ND

125

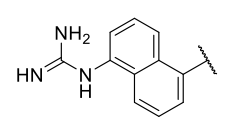

$-\mathrm{Cbz}$

$-\mathrm{PO}(\mathrm{OPh})_{2}$

38

ND

126<smiles>CCCc1ccc(N[AsH2])cc1</smiles>

$-\mathrm{Cbz}$

$-\mathrm{PO}(\mathrm{OPh})_{2}$

10

ND

127

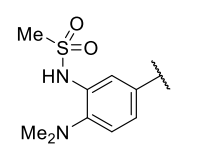

$-\mathrm{Cbz}$

$-\mathrm{PO}(\mathrm{OPh})_{2}$

46

ND

1

2

3

Table 4. Enzymatic inhibition of the exploration around 16, 85 and 92.

\begin{tabular}{|c|c|c|c|c|c|}
\hline \multirow{2}{*}{ Compd. } & \multirow{2}{*}{$\mathbf{R}^{1}$} & \multirow{2}{*}{$\mathbf{R}^{2}$} & \multirow{2}{*}{ Warhead } & \multicolumn{2}{|c|}{ E. coli ClpP inhibition } \\
\hline & & & & $\% I(200 \mu M)$ & $\mathbf{I C}_{50}(\mu \mathrm{M})$ \\
\hline 128 & & & $-\mathrm{PO}(\mathrm{OPh})_{2}$ & 4 & $\mathrm{ND}$ \\
\hline 129 & & $-\mathrm{Cbz}$ & & 1 & ND \\
\hline
\end{tabular}


130

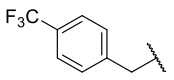<smiles>CCCOCC</smiles>

135<smiles>Nc1cccc(I)c1</smiles><smiles>CCCOCCO</smiles><smiles></smiles>

$-\mathrm{PO}(\mathrm{OPh})_{2}$

136<smiles>Cc1ccc(N)cc1</smiles>

137<smiles>Cc1ccc(I)cc1</smiles>

$-\mathrm{Cbz}$

138<smiles>Cc1ccc(I)cc1</smiles><smiles>CCCOCCO</smiles>

$\mathrm{Cbz}$

146<smiles>C[C@H](N)[C@H]1CCC2CCC21</smiles><smiles>C1CC2CCOC2C1</smiles>

$-\mathrm{PO}(\mathrm{OPh})_{2}$

30

ND

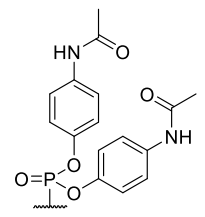

21

ND

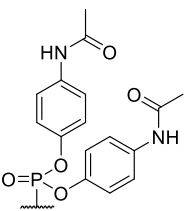

12

ND

147
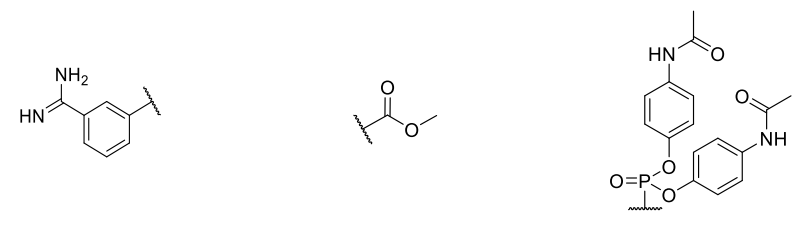

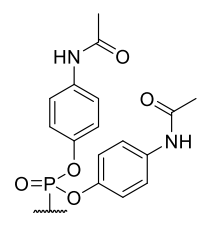

29 ND
20

ND

ND

ND

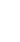

151

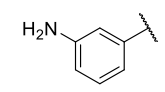

$-\mathrm{Cbz}$

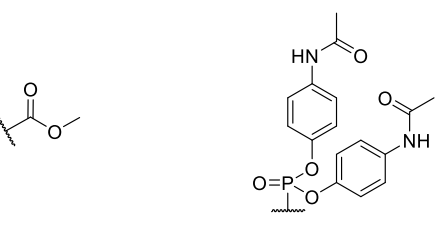

$-\mathrm{CN}$

12

ND

ND

2 The hydrophilic exploration resulted in two additional (107 and 115), with $\mathbf{1 0 7}$ having an $\mathrm{IC}_{50}$ in the

3 sub-micromolar range. Unfortunately, every alteration on the structure of our reference compounds (16,

$4 \quad \mathbf{8 5}$ and $\mathbf{9 2}$ ) led to loss of activity.

5

6 Biological evaluation of hits. The 14 hits identified after the different stages were submitted to further

7 in vitro profiling. The selectivity properties versus chymotrypsin-like serine proteases were evaluated 
1 by screening the 14 compounds against $\alpha$-chymotrypsin (bovine) at $200 \mu \mathrm{M}$ concentration. Most

2 compounds showed no significant inhibition of chymotrypsin with the exception of $\mathbf{8 5}$, which resulted

3 in a residual enzyme activity of $18 \%$ (Table 5).

4 Cytotoxicity was tested against the human cell lines A549 (lung), HepG2 (liver) and HeLa (cervical

5 cancer) in dose response (Table 5). Compounds $\mathbf{8 9 ,} 90$ and $\mathbf{1 0 7}$ were toxic for all cell lines while

6 compounds $\mathbf{6 6}$ and $\mathbf{5 8}$ exerted high cytotoxicity $\left(<10\right.$-fold of compound $\left.\mathrm{IC}_{50}\right)$ against the lung cell line

7 A549. Compounds $\mathbf{7 8}$ and $\mathbf{8 5}$ showed moderate toxicity against A549 and HepG2 cell lines compared

8 with their in vitro potency against the target $\left(\mathrm{IC}_{50}\right)$. The cytotoxicity effects reported here against human

9 cell lines could in principle be caused by the interaction with ClpP present in the human mitochondria

10 as well by $\mathrm{ClpP}$ unrelated mechanisms.

12 Table 5. Enzymatic activity, cytotoxicity and activity against chymotrypsin of the selected hits.

\begin{tabular}{|c|c|c|c|c|c|}
\hline \multirow{2}{*}{ Compd. } & \multirow{2}{*}{$\begin{array}{c}\text { E. coli ClpP } \\
\mathrm{IC}_{50}(\mu \mathrm{M})\end{array}$} & \multicolumn{3}{|c|}{ Cytotoxicity $\mathrm{EC}_{50}(\mu \mathrm{M})$} & \multirow{2}{*}{$\begin{array}{c}\text { Chymotrypsin } \\
\% \text { of remaining } \\
\text { activity }(200 \mu \mathrm{M})\end{array}$} \\
\hline & & HeLa & HepG2 & A549 & \\
\hline 16 & $14.2 \pm 1.3$ & $\geq 100$ & $\geq 100$ & $\geq 100$ & $93.9 \pm 0.8$ \\
\hline 53 & $49.5 \pm 0.5$ & $\geq 100$ & $\geq 100$ & $\geq 100$ & $\geq 100$ \\
\hline 58 & $39.8 \pm 2.9$ & $\geq 100$ & $\geq 100$ & $57.8 \pm 6.7$ & $\geq 100$ \\
\hline 66 & $8.2 \pm 0.8$ & $\geq 100$ & $\geq 100$ & $41.5 \pm 3.8$ & $46.0 \pm 2.9$ \\
\hline 70 & $13.1 \pm 1.2$ & $\geq 100$ & $\geq 100$ & $\geq 100$ & $\geq 100$ \\
\hline 71 & $48.1 \pm 1.7$ & $\geq 100$ & $\geq 100$ & $\geq 100$ & $\geq 100$ \\
\hline 78 & $0.6 \pm 0.1$ & $\geq 100$ & $28.4 \pm 3.5$ & $65.6 \pm 8.3$ & $\geq 100$ \\
\hline 85 & $0.5 \pm 0.0$ & $\geq 100$ & $23.8 \pm 2.8$ & $27.5 \pm 2.3$ & $17.9 \pm 1.6$ \\
\hline 86 & $38.0 \pm 2.4$ & $\geq 100$ & $\geq 100$ & $\geq 100$ & $\geq 100$ \\
\hline 89 & $100.5 \pm 8.0$ & $19.9 \pm 1.8$ & $10.5 \pm 1.4$ & $5.9 \pm 8.5$ & $\geq 100$ \\
\hline 90 & $79.7 \pm 7.2$ & $19.9 \pm 2.3$ & $28.3 \pm 2.5$ & $25.6 \pm 2.7$ & $\geq 100$ \\
\hline 92 & $0.5 \pm 0.0$ & $\geq 100$ & $\geq 100$ & $\geq 100$ & $\geq 100$ \\
\hline
\end{tabular}


1

2 In order to investigate the mode of interaction between $\mathrm{ClpP}$ and selected compounds, surface plasmon

3 resonance measurements were conducted. The known covalently binding compound chloromethyl

$4 \quad$ ketone (Z-LY-CMK) ${ }^{36}$ was used as positive control for irreversible binding.

5 Compounds with $\mathrm{IC}_{50}$ values $<10 \mu \mathrm{M}$ were tested in a range of concentrations. In addition, the known covalent inhibitor Z-LY-CMK was tested as positive control. Z-LY-CMK clearly showed irreversible

7 binding to ClpP, since the compound signal in the sensogram did not return to the baseline (0 RU), even

8 after stop of the compound injection (at $\sim 350$ seconds in all experiments) (Figure 4A). In contrast, all

9 compounds from this study (Figure 4B-F) bound reversibly to the protein, as shown by the signal drop to the baseline after stopping injection. Moreover, the sensorgrams revealed rapid on- and off-rates for

11 all newly identified ClpP inhibitors. 

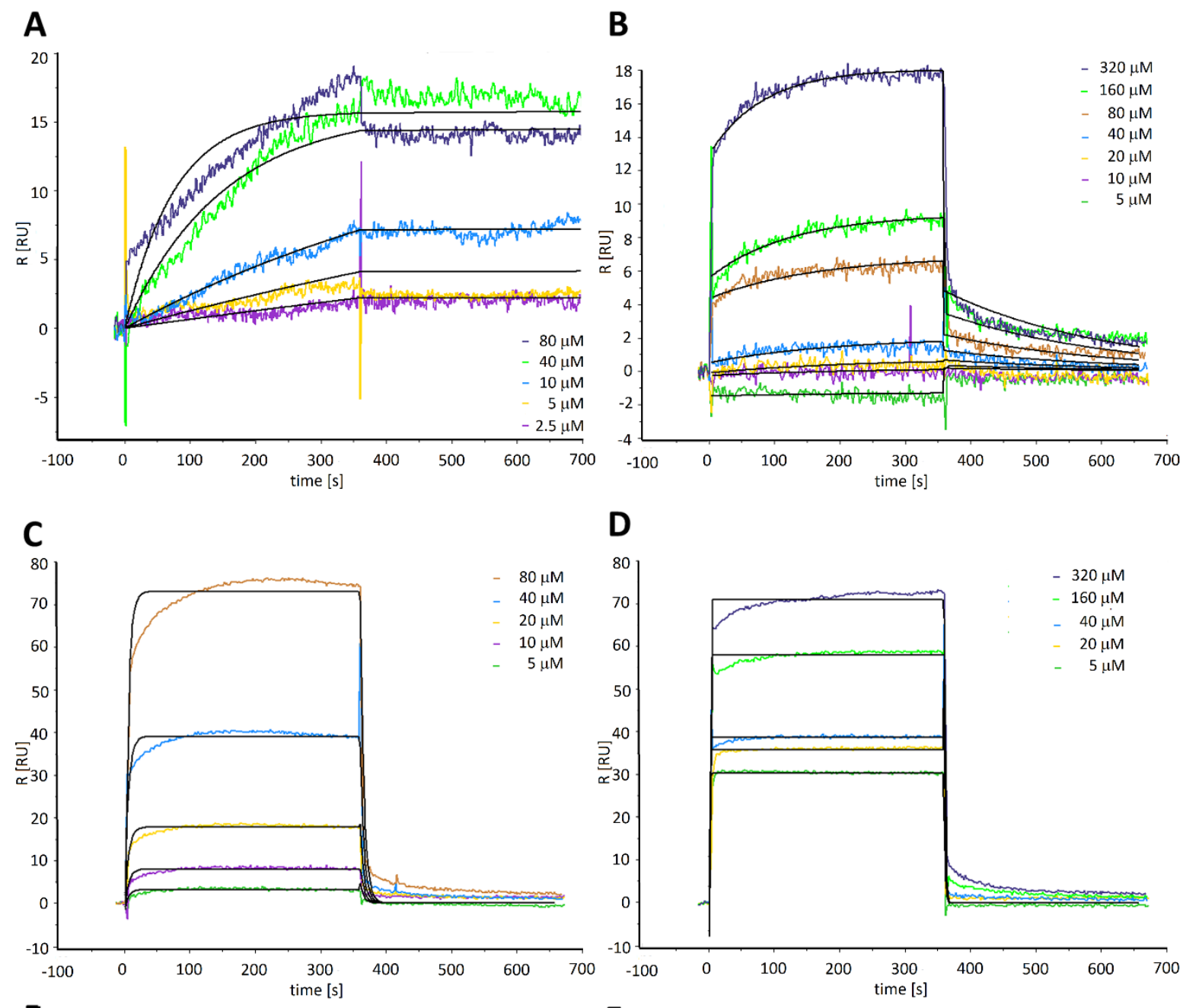

\section{E}

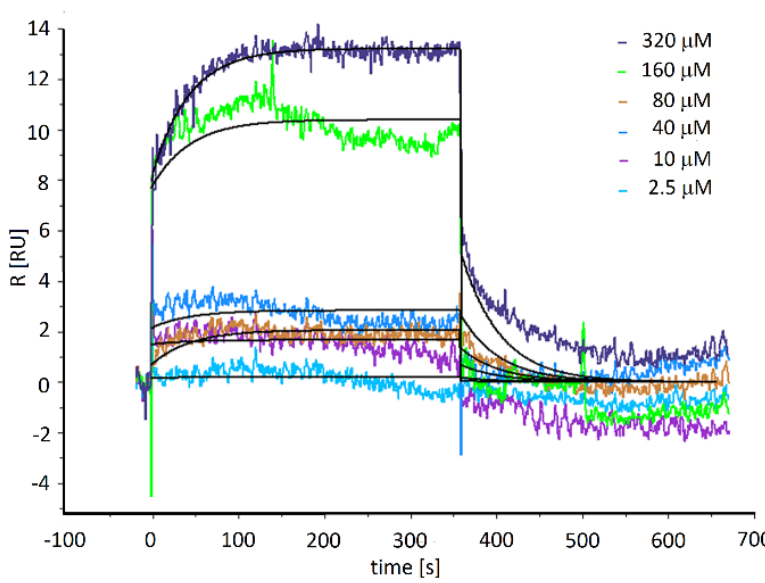

\section{$\mathbf{F}$}

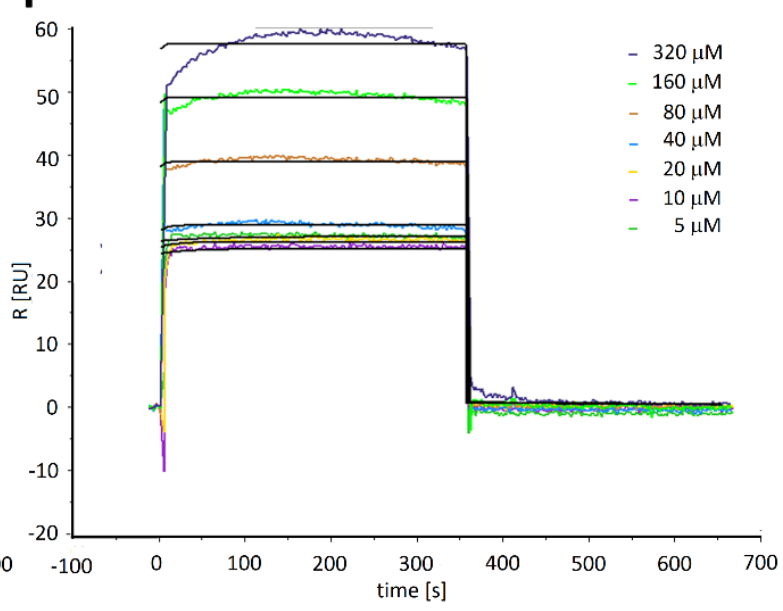

3 Figure 4. Surface plasmon resonance sensorgrams. A) Known covalent inhibitor Z-LY-CMK as control

4 for irreversible binding. ${ }^{36}$ B-F) Selected screening hits, B) 78, C) 107, D) 85, E) 66, F) 92.

6 Antibacterial assays. Since $\mathrm{ClpP}$ is not an essential protease in E. coli, an assay was required to

7 investigate the influence of the $\mathrm{ClpP}$ inhibitors on bacterial growth rates. We utilized a method reported 
1 by Robinson et al., ${ }^{16}$ who observed that a ClpP deletion mutant recovered more slowly from nitric oxide

2 stress than the corresponding wild type, and adapted this assay to a HTS format. Nitric oxide stress was induced by addition of DPTA NONOate ( $2 \mathrm{mM})$ to the $E$. coli $\mathrm{WT}$ and the isogenic E. coli ClpP deletion strain $(\Delta c l p P)$. Although $\triangle c l p P$ strain grew less well under our assay conditions (M9 minimal medium, 96-well format) compared to the wild type, we observed a small but significant difference in time to growth recovery after nitric oxide stress for the $\Delta c l p P$ strain compared to the WT strain (Figure 5). Statistical analysis indicated that the ClpP deletion strain required approximately one hour longer than the wild type to for growth recovery (see Figure $\mathbf{S 2}$ in the supporting information).

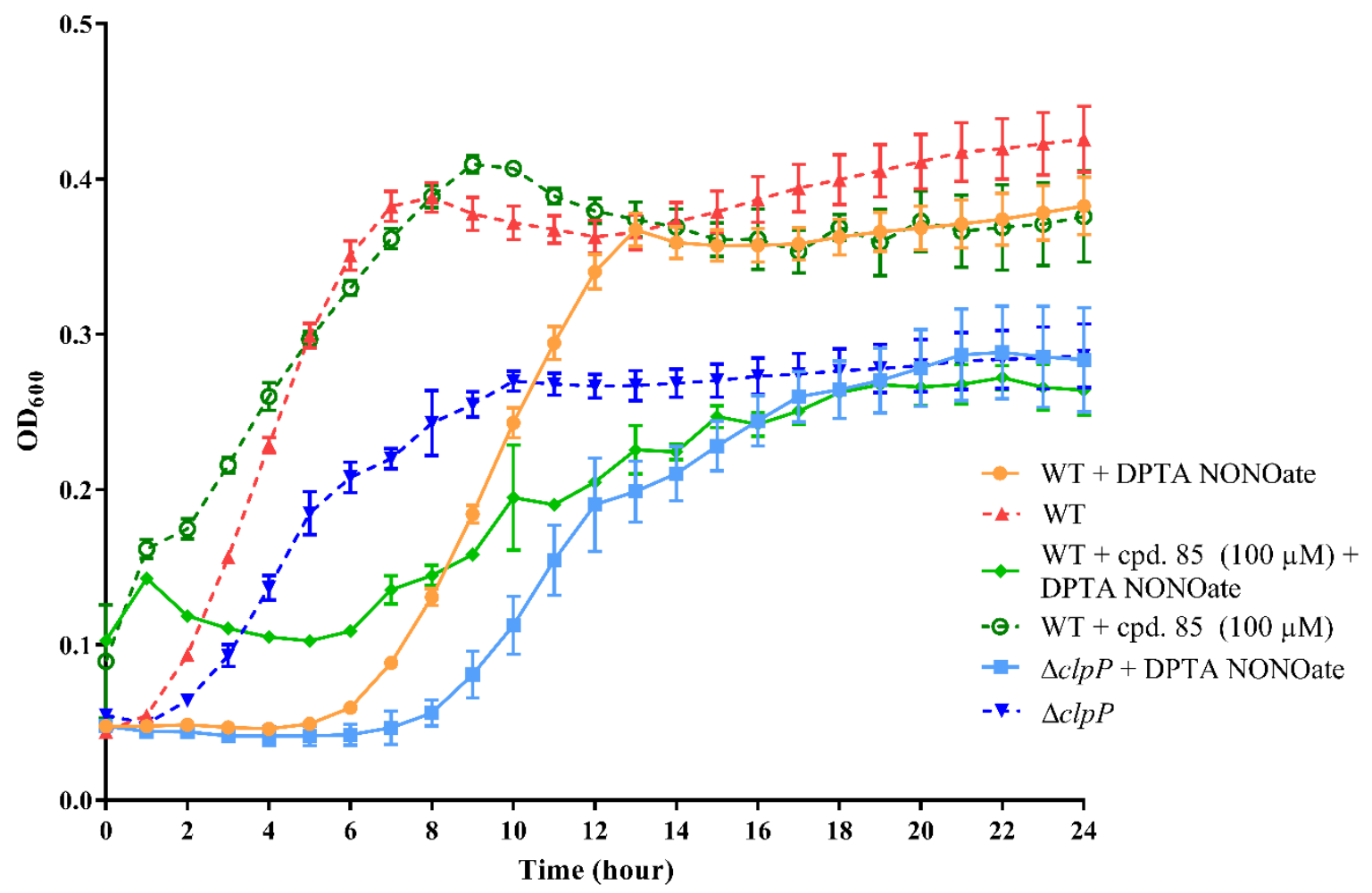

9

Figure 5. Comparison of the the growth curves, depicted by $\mathrm{OD}_{600}$, of E. coli WT and the isogenic mutant E. coli JW0427-1 (clpP-defective mutant), both in absence and presence of the $\cdot \mathrm{NO}$ chemical donor DPTA NONOate (2 mM) in minimal M9 medium supplemented with $10 \mathrm{mM}$ of glucose. Effect of compound $\mathbf{8 5}$ on bacterial growth is quantified by $\mathrm{OD}_{600}$ of E. coli $\mathrm{BW} 25-113$ (WT) in presence and in absence of DPTA NONOate $(2 \mathrm{mM})$. Each value represents the mean of three independent experiment \pm standard deviation. 
1 The fourteen hits identified in this study were tested in WT strain in presence of nitric oxide stress. Only compound 85 showed a remarkable effect in the WT growth (Figure 5), opposite to all the other compounds which were also tested but without showing any effect. Therefore, while not every hit achieved the desired inhibition, the effects of compound $\mathbf{8 5}$ on the stressed WT strain showed a comparable growth delay observed to the $\triangle c l p P$ strain exposed to nitric oxide stress conditions, consistent with a potential ClpP protease inhibition mediated effect of compound $\mathbf{8 5}$.

Figure 5 shows that in the presence of nitric oxide stress the growth rate of the WT strain is reduced, and requires additional $4 \mathrm{~h}$ to reach maximum absorbance (orange circle versus red triangle). The growth rate of the $\triangle c l p P$ strain compared to the WT strain is reduced, and is further reduced in the presence of nitric oxide stress, taking an additional $6 \mathrm{~h}$ to reach maximum absorbance (light blue square versus dark blue inverted triangle). The addition of compound $\mathbf{8 5}$ at $100 \mu \mathrm{M}$ does not affect the growth rate of the WT strain (green ring versus red triangle). However, under nitric oxide stress conditions, the WT strain growth is reduced in presence of compound $\mathbf{8 5}$ compared to nitric oxide stress only (green diamond versus orange circle) and, interestingly, the growth of $\Delta c l p P$ is similar to that of the WT strain in the presence of compound $\mathbf{8 5}$ (blue square versus green diamond). Moreover, the effect of compound 85 in $\triangle c l p P$ growth was tested in presence and absence of nitric oxide stress to ensure that the compound-mediated effect on the WT bacteria growth was due to ClpP inhibition and not due to offtarget effect. As shown in Figure $\mathbf{S 3}$ (in the supporting information), the compound did not significantly affect the growth of the $\triangle c l p P$ bacteria either in absence or presence of nitric oxide stress conditions. This confirms that the effect of $\mathbf{8 5}$ on WT bacteria under nitric oxide stress conditions is most likely mediated through its inhibition of ClpP.

Selected compounds were also screened against the wild-type strains of S. aureus, Acinetobacter baumannii, Klebsiella pneumoniae, Pseudomonas aeruginosa and E. coli in a standard bacterial growth assay. Two E. coli mutants with either $l p x C$ defect (impaired in lipidA synthesis) or tolC defect (efflux pump defect) were also included. At $100 \mu \mathrm{M}$ compound concentration, only 115 inhibited the growth of $S$. aureus WT (\% inhibition of growth $99.9 \pm 0.04)$, while $\mathbf{9 0}(98.9 \pm 0.05), 107(69.9 \pm 5.6)$ and 115 $(99.0 \pm 0.5)$ inhibited the efflux pump deficient $E$. coli strain. The mode of action underlying this growth 
inhibition remains elusive and could be caused by mechanisms unrelated to $E$. coli $\mathrm{ClpP}$. In order to investigate whether the compounds are efflux pump substrates, the growth of $E$. coli wild type was examined in presence of test compounds (concentration $50 \mu \mathrm{M}$ ) and $25 \mu \mathrm{g} / \mathrm{ml}$ of phenylalanine-arginine beta-naphthylamide (PAßN), a known efflux pump substrate. At $24 \mathrm{~h}$ compound 90 inhibited bacterial growth $(98.5 \pm 1.2)$. In order to verify whether the observed effect of compound $\mathbf{9 0}$ was due to ClpP inhibition, the assay was repeated using the E.coli $\triangle c l p P$ strain. The same output of the assay with the wild type strain was obtained (growth inhibition $99.4 \pm 0.7$ ), we can therefore assest that compound 90 addresses a different target that is influencing bacterial growth in presence of the efflux pump substrate. A summary of the compounds active in bacteria can be found in the supporting information (Table S1).

Molecular docking. Potential binding modes of the most potent inhibitors (92 and $\mathbf{8 5})$ within the active site of ClpP were investigated by molecular docking of the compounds into the X-ray crystal structure of E. coli ClpP (PDB ID 2FZS) using GOLD.

Clustering of the docking poses of 92 revealed two preferred binding modes (Figure 6A-D). The topranked pose of the first cluster (Figure 6A\&B) shows the benzamidine group to be positioned deeply within the S1 pocket, while a hydrogen bond network between the phosphonate and residues Gly68 (constituent of the oxanion hole) and Leu125 is well established. However, the distance between the side chain oxygen atom of Ser97 and the phosphorus atom of the ligand is larger than required for the expected nucleophilic attack (3.35 Å). The second predominant binding mode revealed the benzamidine group to be solvent-exposed and the docked ligand shares several hydrogen bonds with the protein (Figure 6C\&D). The interaction energy between docked ligand and ClpP was calculated using the Amber10:EHT force field. The top-ranked docking pose of cluster 1 ( $\mathrm{R}^{1}$ moiety placed in the $\mathrm{S} 1$ pocket) revealed a more favorable interaction energy $\left(-62.5 \mathrm{kcal} \mathrm{mol}^{-1}\right)$ compared to the top-ranked pose of cluster $2\left(-54.6 \mathrm{kcal} \mathrm{mol}^{-1}\right)$.

The predicted binding mode of $\mathbf{8 5}$ is shown in Figure $\mathbf{6 E \& F}$. Only one cluster was identified and the binding mode revealed the phenyl groups of the diarylphosphonate to be solvent-exposed, whilethe aniline moiety is positioned inside the S1 pocket. Again, several hydrogen bonds are formed between 
1 the phosphonate group and the protein, but Ser97 did not display a favorable position for the nuclephilic 2 attack.

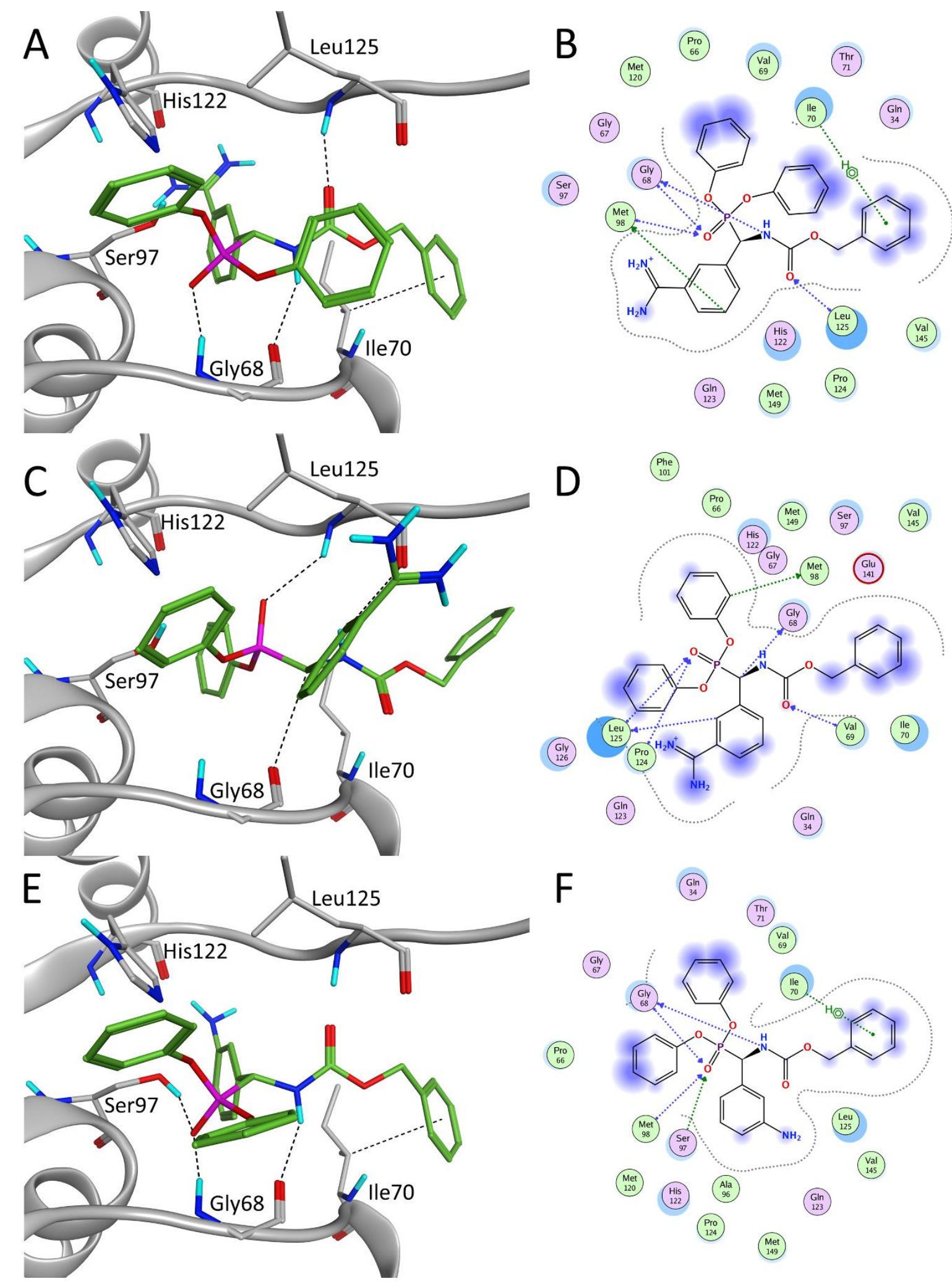

$4 \quad$ Figure 6. Computational prediction of potential binding modes for $\mathbf{9 2}$ and $\mathbf{8 5}$ within the E. coli ClpP 5 crystal structure (PDB ID: 2FZS). A and C) Docking poses of the two main docking clusters of 
compound 92. E) Pose of compound $\mathbf{8 5}$. Black dotted lines indicate hydrogen bonds between the ligands and the protein. B, D and F) 2D interaction plots between protein and 92 of cluster 1 (B), cluster 2 (D) and $85(F)$ where the polar residues are indicated in purple, the non-polar or charged residues in green, and the solvent exposure by blue shadow. The black dotted line designates the proximity contour. The green dotted arrows indicate hydrogen bonds involving amino acid side chain atoms (donors and acceptors) while blue dotted arrows indicate hydrogen bonds accepted or donated by protein backbone atoms. Moreover, arene-H interactions are shown as green dotted line.

\section{DISCUSSION AND CONCLUSIONS}

An extensive chemical exploration and enzymatic screening identified 14 compounds inhibiting $E$. coli $\mathrm{ClpP}$ in vitro with sub-micromolar $\mathrm{IC}_{50}$ values for $\mathbf{7 8 ,} 85,92$ and 107. Despite the expected hydrophobicity of the protease recognition pocket, compounds containing polar residues in $\mathrm{R}^{1}$ position displayed the highest inhibitory activity. Molecular docking analysis of compound $\mathbf{8 5}$ and $\mathbf{9 2}$ revealed that the most favorable poses had the aniline or benzamidine group deeply positioned within the recognition pocket. The diphenyl phosphonate warhead was crucial, with none of the replacements or small modifications attempted maintaining the inhibitory activity.

Surface plasmon resonance demonstrated a reversible binding for all tested compounds. With help of the docking studies of $\mathbf{8 5}$ and $\mathbf{9 2}$, it can be hypothesized that the inhibitory poses do not allocate the phosphonate esters of the ligands in a favorable position to form the pentacoordinate transition state (Figure 2) after the attack by Ser97. Albeit unexpected, this reversible binding of the chemical family has a precedent in the KLK4 inhibitors reported by Van Soom et al. ${ }^{48}$

Benzamidine 92 emerges as the safest option for further optimization due to its potent enzymatic inhibition, absence of activity against chymotrypsin and lack of toxicity against the tested eukaryotic cell lines. Even though the latter could be related to a compound's incapability to enter eukaryotic cells or to the possibility of being substrate of an efflux pump and would also explain the lack of activity in the nitric oxide stress assay. At the same time, aniline $\mathbf{8 5}$ showed reduction of growth in E. coli WT under nitric oxide stress conditions, consistent with a ClpP-mediated effect. However, it requires further improvement in terms of limiting its toxicity against human cell lines and decreasing activity against 
1 chymotrypsin. Both compounds, as well as 16, 66, 70, 78 and 107 are significantly more potent ClpP

2 inhibitors compared to the so far only known inhibitor Z-LY-CMK. In order to enlarge the scope and

3 to understand the lack of effect of some of our inhibitors in the nitric oxide stress assay, further

4 exploration of chemical alternatives is needed. Given the already known potential of covalent binding

5 compounds as antimicrobial agents, for example the huge success of $\beta$-lactam antibiotics (e.g. penems,

6 cephalosporins, carbapenems, monobactams), the development of a covalent binder for E. coli ClpP

7 should focus on the replacement of the diaryl phosphonate by a different covalent warhead for serine

8 proteases. The comprehensive $\mathrm{R}^{1}$ moiety library developed in this study may guide future work in the

9 field combining them with warheads such as boronates, based on the success of bortezomib with $M$.

10 tuberculosis $\mathrm{ClpP}$ and its inhibition of human $26 \mathrm{~S}$ proteasome. ${ }^{33}$ 
2 CHEMISTRY. Reagents were obtained from commercial sources and were used without further purification. Characterization of all compounds was done with ${ }^{1} \mathrm{H}$ and ${ }^{13} \mathrm{C}$ NMR and mass spectrometry. ${ }^{1} \mathrm{H}$ and ${ }^{13} \mathrm{C}$ NMR spectra were recorded on a $400 \mathrm{MHz}$ Bruker Avance III Nanobay spectrometer with Ultrashield working at $400 \mathrm{MHz}$ and $100 \mathrm{MHz}$ respectively; and analyzed by use of MestReNova analytical chemistry software. Chemical shifts are in ppm, and coupling constants are in hertz (Hz). The UPLC (Ultra Performance liquid chromatography), used to quantify the purity of the products was an ACQUITY UPLC H-Class System with a TUV detector Waters coupled to a MS detector Waters QDa. An Acquity UPLC BEH C18 $1.7 \mu \mathrm{m}(2.1 \times 50 \mathrm{~mm})$ column was used and as eluent a mixture of $0.1 \%$ FA in $\mathrm{H}_{2} \mathrm{O}, 0.1 \%$ FA in $\mathrm{MeCN}, \mathrm{H}_{2} \mathrm{O}$ and $\mathrm{MeCN}$. The wavelengths for $\mathrm{UV}$ detection were $254 \mathrm{~nm}$ and $214 \mathrm{~nm}$. Key target compounds for the activity were analysed by High Resolution Mass: $10 \mu \mathrm{L}$ of each sample (conc. $=10^{-5} \mathrm{M}$ ) was injected using the CapLC system (Waters, Manchester, UK) and electrosprayed using a standard electrospray source. Samples were injected with an interval of 5 min. Positive ion mode accurate mass spectra were acquired using a Q-TOF II instrument (Waters, Manchester, UK). The MS was calibrated prior to use with a $0.2 \% \mathrm{H}_{3} \mathrm{PO}_{4}$ solution. The spectra were lock mass corrected using the known mass of the nearest $\mathrm{H}_{3} \mathrm{PO}_{4}$ cluster. Where necessary, flash column chromatography was performed on a Biotage ISOLERA One flash system equipped with an internal variable dual wavelength diode array detector $(200-400 \mathrm{~nm})$. For normal phase purifications SNAP cartridges $(4-100 \mathrm{~g}$, flow rate of $10-100 \mathrm{~mL} / \mathrm{min})$ were used, and reverse phase purifications were done making use of KP-C18 cartridges (4 - $30 \mathrm{~g}$, flow rate of $10-50 \mathrm{~mL} / \mathrm{min}$ ). Dry sample loading was done by self-packing samplet cartridges using Celite 545. Gradients used varied for each purification.

The following sections comprise the synthetic procedures and analytical data for all compounds reported in this manuscript. Every reaction was performed under $\mathrm{N}_{2}$ atmosphere if not stated otherwise. Several synthetic procedures that were used in the preparation of intermediates and final products are summarized here as "General Procedures". Target compounds were obtained with a purity $>95 \%$ and as amorphous solids, unless stated otherwise. 
1 General Procedure A. $\mathrm{K}_{2} \mathrm{CO}_{3}$ (3 eq) was added to a solution of the selected aromatic alcohol (1 eq)

2 in anhydrous DMF (1.5 M) and the reaction mixture was stirred at $\mathrm{rt}$ for 30 min. Benzyl bromide

3 (1.05 eq) was added dropwise to the reaction mixture, that was left stirring for $4 \mathrm{~h}$ at $\mathrm{rt}$. The reaction

4

5

6

7

8 mixture was quenched with $\mathrm{H}_{2} \mathrm{O}$ and extracted with EtOAc. The combined EtOAc were washed with $\mathrm{H}_{2} \mathrm{O}$, brine, dried over $\mathrm{MgSO}_{4}$, filtered and the solvent was evaporated in vacuo to yield the corresponding protected alcohol.

General Procedure B. Dess-Martin periodinane (1.2 eq) was added portionwise to a stirred solution of the selected primary alcohol $(1 \mathrm{eq})$ in anhydrous DCM $(0.2 \mathrm{M})$ at $0{ }^{\circ} \mathrm{C}$. The mixture was stirred at $\mathrm{rt}$ for $4 \mathrm{~h}$ and then the solvent was evaporated in vacuo. The crude was purified by flash column chromatography $\left(\mathrm{SiO}_{2}, \mathrm{EtOAc}\right.$ in heptane, $0 / 100$ to $\left.100 / 0\right)$. The desired fractions were collected and concentrated to yield the corresponding aldehyde.

General Procedure C. Selected aldehyde (1 eq), benzyl carbamate (if not stated otherwise) (1 eq) and triphenyl phosphite (if not stated otherwise) (1.1 eq) were dissolved in anhydrous DCM (0.3 M). Then, copper(II) triflate $(0.1 \mathrm{eq})$ was added and the mixture was stirred at $\mathrm{rt}$ for $16 \mathrm{~h}$. Then, solvent was evaporated and the residue dissolved in the minimum amount of $\mathrm{MeOH}$. The solution was kept at $-20{ }^{\circ} \mathrm{C}$ for $48 \mathrm{~h}$ and then filtrated. When precipitation did not succeed, the crude was purified by flash column chromatography ( $\mathrm{SiO}_{2}, \mathrm{EtOAc}$ in heptane, 0/100 to 100/0) and if still not pure, by reverse phase column chromatography $\left(\mathrm{C} 18, \mathrm{MeOH}\right.$ in $\mathrm{H}_{2} \mathrm{O}, 0 / 100$ to $\left.100 / 0\right)$. The desired fractions were collected and concentrated to yield the corresponding $\alpha$-amino diarylphosphonate as a racemic mixture.

General Procedure D. To a stirred solution of the selected protected alcohol (1 eq) and pentamethylbenzene ( 3 eq) in anhydrous DCM $(0.3 \mathrm{M})$ was added boron trichloride (1 $\mathrm{M}$ in hexanes) (2 eq) dropwise at $-78{ }^{\circ} \mathrm{C}$. After 15 min, the reaction was quenched with $\mathrm{CHCl}_{3}: \mathrm{MeOH}(10: 1,1 \mathrm{~mL})$ at $-78^{\circ} \mathrm{C}$, and the resulting mixture was allowed to reach rt. The organic solvents were evaporated in vacuo. The residue was purified by flash column chromatography $\left(\mathrm{SiO}_{2}, \mathrm{EtOAc}\right.$ in heptane $0 / 100$ to 100/0) and then by reverse column chromatography (C18, $\mathrm{MeOH}$ in $\mathrm{H}_{2} \mathrm{O} 0 / 100$ to 100/0). The desired fractions were then collected and evaporated to yield the corresponding deprotected alcohol.

General Procedure E. To a solution of the selected acid (1 eq) in anhydrous DCM $(0.3 \mathrm{M})$ at $0{ }^{\circ} \mathrm{C}$ was added 4-methylmorpholine (1.2 eq). This was followed by dropwise addition of isobutyl chloroformate 
1 (1.2 eq) over $20 \mathrm{~min}$. After $30 \mathrm{~min}$ of stirring at $0{ }^{\circ} \mathrm{C}, \mathrm{NH}_{3}$ (25\%, aq. sol.) (6 eq) was added portionwise 2 over $5 \mathrm{~min}$. The reaction was stirred for $16 \mathrm{~h}$ at $\mathrm{rt}$ and then the DCM was evaporated in vacuo. The remaining solution was extracted with EtOAc, washed with citric acid citric acid (5\% aq. sol.), $\mathrm{NaHCO}_{3}$ (sat. sol.) and brine, dried over $\mathrm{Na}_{2} \mathrm{SO}_{4}$, filtered and the solvents were evaporated in vacuo to yield the corresponding amide.

General Procedure F. A solution of Burgess reagent $(2.1 \mathrm{eq})$ in anhydrous DCM $(0.3 \mathrm{M})$ was added over a suspension of the corresponding amide (1 eq) in anhydrous DCM (0.3 M) and the reaction mixture was stirred for $24 \mathrm{~h}$. The reaction mixture was washed with $\mathrm{AcOH}$ (1\% aq. sol.), brine, dried over $\mathrm{Na}_{2} \mathrm{SO}_{4}$, filtered and the solvents were evaporated in vacuo. The residue was purified by flash column chromatography $\left(\mathrm{SiO}_{2}\right.$, EtOAc in heptane $0 / 100$ to 100/0). The desired fractions were collected and concentrated to yield the corresponding nitrile.

General Procedure G. Hydrochloric acid (4 M in dioxane) (20 eq) was added dropwise to a solution of the selected protected amine $(1 \mathrm{eq})$ in anhydrous $\mathrm{MeOH}(0.1 \mathrm{M})$ at $0{ }^{\circ} \mathrm{C}$. The reaction mixture was stirred at $\mathrm{rt}$ for $16 \mathrm{~h}$. The mixture was concentrated. The solid was then dissolved in a mixture of $\mathrm{Na}_{2} \mathrm{CO}_{3}$ (10\% aq. sol.). The free salt was extracted with EtOAc and the combined organic layers were then acidified with $\mathrm{HCl}(2 \mathrm{M})$ until $\mathrm{pH}=1$ to get the hydrochloric salt again. The organic layer was further extracted with $\mathrm{HCl}$ and the combined aqueous layers evaporated. The excess of $\mathrm{HCl}$ was removed by coevaporation with toluene. In case of final compounds, the crude was purified by reverse column chromatography (18C, $\mathrm{MeOH}$ in $\mathrm{H}_{2} \mathrm{O}, 0 / 100$ to $100 / 0$ ). The desired fractions were then collected and evaporated to yield the corresponding deprotected amine as a hydrochloride salt.

General Procedure H. Selected Boc-protected compound (1 eq) was dissolved in anhydrous DCM $(0.02 \mathrm{M})$ and TFA $(100 \mathrm{eq})$ was added and the solution was stirred for $1 \mathrm{~h}$ at $\mathrm{rt}$. The solvents were evaporated in vacuo and the mixture was co-evaporated with heptane to yield corresponding deprotected amine compound as a TFA salt.

General Procedure I. To a solution of the selected amine (1 eq) in anhydrous DCM (0.04 M) was added $\mathrm{Et}_{3} \mathrm{~N}$ ( $3 \mathrm{eq}$ ) followed by $N, N^{\prime}$-bis-Boc-1-guanylpyrazole ( 2 eq). The reaction was stirred at $\mathrm{rt}$ for $48 \mathrm{~h}$. After this time, the solvent was evaporated in vacuo and the crude was purified by flash column 
1 chromatography $\left(\mathrm{SiO}_{2}\right.$, EtOAc in heptane $0 / 100$ to 100/0) to yield the corresponding protected 2 guanidine.

3 General Procedure J. Selected acid chloride (1.2 eq) was added dropwise to a solution of the selected

4

5

6

7

8

9 aniline (1 eq) and DIPEA (1.5 eq) in anhydrous DCM (0.02 M) and the reaction mixture was stirred for $2 \mathrm{~h}$ at rt. Then, the reaction was quenched with $\mathrm{HCl}(1 \mathrm{M})$. This mixture was extracted with DCM, combined organic layers were washed with brine, dried over $\mathrm{Na}_{2} \mathrm{SO}_{4}$, filtered and the solvent was evaporated in vacuo. The crude was then purified by flash column chromatography $\left(\mathrm{SiO}_{2}, \mathrm{EtOAc}\right.$ in heptane: 20/80 to 80/20). The desired fractions were collected and concentrated to yield the corresponding carbamate.

General Procedure K. Zinc was first purified by stirring commercial $\mathrm{Zn}$ dust with $\mathrm{HCl}$ (2\% aq. sol.) for $1 \mathrm{~min}$. The acid was removed by filtration, and the $\mathrm{Zn}$ was washed with $\mathrm{HCl}$ (2\% aq. sol.), distilled $\mathrm{H}_{2} \mathrm{O}$, EtOH, and finally with $\mathrm{Et}_{2} \mathrm{O}$. Then, selected nitrobenzyl compound (1 eq) was dissolved in mixture of THF $(0.03 \mathrm{M})$ and $\mathrm{NH}_{4} \mathrm{Cl}$ (sat. aq. sol.) $(0.03 \mathrm{M})$ and cooled to $0{ }^{\circ} \mathrm{C}$. The mixture was treated with the pre-treated $\mathrm{Zn}(5 \mathrm{eq})$ at vigorous stirring. The reaction mixture was stirred at $\mathrm{rt}$ for $1 \mathrm{~h}$. The reaction mixture was filtered through celite while rinsing with THF. The mixture was extracted with EtOAc, washed with brine, dried over $\mathrm{Na}_{2} \mathrm{SO}_{4}$ and concentrated. When conversion was not complete, the crude was purified by reverse phase column chromatography $\left(\mathrm{C} 18, \mathrm{MeOH}\right.$ in $\mathrm{H}_{2} \mathrm{O}, 0 / 100$ to 100/0). The desired fractions were collected and concentrated to afford the corresponding aniline.

General Procedure L. A mixture of the selected cyanophenyl compound (1 eq), hydroxylammonium chloride (2 eq) and DIPEA (2 eq) in EtOH $(0.05 \mathrm{M})$ was heated to $80{ }^{\circ} \mathrm{C}$ for $48 \mathrm{~h}$. The crude was filtrated, the filtrate was evaporated and the crude was dissolved in $\mathrm{MeCN}(0.1 \mathrm{M})$. Acetyl ether (3 eq) was added and the reaction was stirred at $\mathrm{rt}$ for $1 \mathrm{~h}$. Then, the crude was concentrated, dissolved in $\mathrm{MeOH}$ and kept at $-20^{\circ} \mathrm{C}$ for $16 \mathrm{~h}$. The solid was filtered and rinsed with cold $\mathrm{MeOH}$, the filtrate was concentrated to yield the corresponding $N$-acetoxycarbamimidoyl)phenyl compound.

General Procedure M. The selected $N$-acetoxycarbamimidoyl)phenyl compound (1 eq) was dissolved in $\mathrm{AcOH}(0.03 \mathrm{M})$ and wet $\mathrm{Pd}(\mathrm{II}) / \mathrm{C} 10 \mathrm{wt} . \%$ (0.1 eq) was added. The reaction mixture was stirred at rt under $\mathrm{H}_{2}$ atmosphere (1 atm) for $24 \mathrm{~h}$. Then, the palladium was filtrated off through a pad of celite from the mixture and the solvent was evaporated in vacuo. The crude was dissolved in $\mathrm{MeOH}$ 
and kept at $-20{ }^{\circ} \mathrm{C}$ for $16 \mathrm{~h}$. The solid was filtered and washed with cold $\mathrm{MeOH}$. Then, the solid was purified by reverse phase column chromatography $\left(\mathrm{C} 18, \mathrm{MeOH}\right.$ in $\mathrm{H}_{2} \mathrm{O}, 0 / 100$ to $\left.100 / 0\right)$. The desired fractions were collected and concentrated to yield the corresponding aromatic amidine.

2-(4-(Benzyloxy)phenyl)ethan-1-ol (1). General procedure A with 2-(4-hydroxyphenyl) ethanol (2.00 g, $14.5 \mathrm{mmol}$ ) to yield 2-(4-(benzyloxy)phenyl)ethanol (2.75 g, $12.03 \mathrm{mmol}, 83 \%$ yield). ${ }^{1} \mathrm{H}$ NMR (400 $\left.\mathrm{MHz}, \mathrm{CDCl}_{3}\right) \delta: 7.46-7.28(\mathrm{~m}, 5 \mathrm{H}), 7.16-7.11(\mathrm{~m}, 2 \mathrm{H}), 6.96-6.89(\mathrm{~m}, 2 \mathrm{H}), 5.04(\mathrm{~s}, 2 \mathrm{H}), 3.81(\mathrm{t}$, $J=6.5 \mathrm{~Hz}, 2 \mathrm{H}), 2.80(\mathrm{t}, J=6.5 \mathrm{~Hz}, 2 \mathrm{H}) . \mathrm{MS}(\mathrm{ESI}) \mathrm{m} / z 211.0[\mathrm{M}-\mathrm{OH}]^{+}$.

2-(3-(Benzyloxy)phenyl)ethan-1-ol (2). General procedure A with 2-(3-hydroxyphenyl)-ethanol (800 $\mathrm{mg}, 5.79 \mathrm{mmol})$ to yield 2-(3-(benzyloxy)phenyl)ethanol (1.25 g, $5.47 \mathrm{mmol}, 94 \%$ yield) as a white solid. MS (ESI) $m / z 211.0[\mathrm{M}-\mathrm{OH}]^{+}$.

2-(p-Tolyl)acetaldehyde (3). General procedure B with 2-(4-methylphenyl) ethanol (800 mg, 5.87 mmol) to yield 2-(p-tolyl)acetaldehyde (580 mg, $4.32 \mathrm{mmol}, 74 \%$ yield) as a colourless oil. No ionization found. ${ }^{1} \mathrm{H} \mathrm{NMR}\left(400 \mathrm{MHz}, \mathrm{CDCl}_{3}\right) \delta: 9.73(\mathrm{t}, J=2.5 \mathrm{~Hz}, 1 \mathrm{H}), 7.18(\mathrm{~d}, J=8.0 \mathrm{~Hz}, 2 \mathrm{H}), 7.12$ - $7.10(\mathrm{~m}, 2 \mathrm{H}), 3.65(\mathrm{~d}, J=2.5 \mathrm{~Hz}, 2 \mathrm{H}), 2.35(\mathrm{~s}, 3 \mathrm{H})$.

2-(4-Methoxyphenyl)acetaldehyde (4). General procedure B with 4-methoxybenzeneethanol (600 mg, $3.94 \mathrm{mmol}$ ) to yield 2-(4-methoxyphenyl)acetaldehyde (292 mg, $1.94 \mathrm{mmol}$, 49\% yield) as a colourless oil. ${ }^{1} \mathrm{H}$ NMR $\left(400 \mathrm{MHz}, \mathrm{CDCl}_{3}\right) \delta: 9.72(\mathrm{t}, J=2.5 \mathrm{~Hz}, 1 \mathrm{H}), 7.17-7.10(\mathrm{~m}, 2 \mathrm{H}), 6.94-6.88$ $(\mathrm{m}, 2 \mathrm{H}), 3.81(\mathrm{~s}, 3 \mathrm{H}), 3.63(\mathrm{~d}, J=2.5 \mathrm{~Hz}, 2 \mathrm{H})$. No ionization found.

2-(Naphthalen-2-yl)acetaldehyde (5). General procedure B with 2-(naphthalen-1-yl)ethanol (100 mg, $0,58 \mathrm{mmol}$ ) to yield 2-(naphthalen-2-yl)acetaldehyde (56 $\mathrm{mg}, 0.33 \mathrm{mmol}, 57 \%$ yield) as a colourless oil. ${ }^{1} \mathrm{H}$ NMR (400 MHz, $\left.\mathrm{CDCl}_{3}\right) \delta: 9.80(\mathrm{t}, J=2.5 \mathrm{~Hz}, 1 \mathrm{H}), 7.94-7.83(\mathrm{~m}, 3 \mathrm{H}), 7.60-7.40(\mathrm{~m}, 4 \mathrm{H})$, $4.12(\mathrm{~d}, J=2.5 \mathrm{~Hz}, 2 \mathrm{H})$. No ionization found.

2-(4-Fluorophenyl)acetaldehyde (6). General procedure B with 2-(4-fluorophenyl)-ethanol (0.89 mL, $7.31 \mathrm{mmol}$ ) to yield 2-(4-fluorophenyl)acetaldehyde (545 $\mathrm{mg}, 3.95 \mathrm{mmol}, 55 \%$ yield) as a colourless oil. ${ }^{1} \mathrm{H}$ NMR (400 MHz, $\left.\mathrm{CDCl}_{3}\right) \delta: 9.75(\mathrm{t}, J=2.0 \mathrm{~Hz}, 1 \mathrm{H}), 7.18(\mathrm{~m}, 2 \mathrm{H}), 7.06(\mathrm{~m}, 2 \mathrm{H}), 3.68(\mathrm{~d}, J=2.0$ $\mathrm{Hz}, 2 \mathrm{H})$. No ionization found. 
2-(4-(Trifluoromethyl)phenyl)acetaldehyde (7). General procedure B with 2-(4-fluorophenyl)ethanol (200 mg, $1.26 \mathrm{mmol})$ to yield 2-(4-(trifluoromethyl)phenyl)acetaldehyde (111 mg, $0.59 \mathrm{mmol}$, $56 \%$ yield) as a colourless oil. No ionization found. ${ }^{1} \mathrm{H} \mathrm{NMR}\left(400 \mathrm{MHz}, \mathrm{CDCl}_{3}\right) \delta: 9.79(\mathrm{t}, J=2.0 \mathrm{~Hz}$, $1 \mathrm{H}), 7.63(\mathrm{~d}, J=8.0 \mathrm{~Hz}, 2 \mathrm{H}), 7.34(\mathrm{~d}, J=8.0 \mathrm{~Hz}, 2 \mathrm{H}), 3.79(\mathrm{~d}, J=2.0 \mathrm{~Hz}, 2 \mathrm{H})$.

2-(4-(Benzyloxy)phenyl)acetaldehyde (8). General procedure B with 2-(4-(benzyloxy)phenyl)ethanol (1) $(2.75 \mathrm{~g}, 12.0 \mathrm{mmol})$ to yield 2-(4-(benzyloxy)phenyl)acetaldehyde $(2.03 \mathrm{~g}, 8.99 \mathrm{mmol}, 75 \%$ yield $)$ as a colourless oil. ${ }^{1} \mathrm{H} \mathrm{NMR}\left(400 \mathrm{MHz} \mathrm{CDCl}_{3}\right) \delta: 9.73(\mathrm{t}, J=2.5 \mathrm{~Hz}, 1 \mathrm{H}), 7.51-7.34(\mathrm{~m}, 5 \mathrm{H}), 7.22$ $7.10(\mathrm{~m}, 2 \mathrm{H}), 7.07-6.98(\mathrm{~m}, 2 \mathrm{H}), 5.09(\mathrm{~s}, 2 \mathrm{H}), 3.63(\mathrm{~d}, J=2.5 \mathrm{~Hz}, 2 \mathrm{H})$. No ionization found.

2-(3-(Benzyloxy)phenyl)acetaldehyde (9). General procedure B with 2-(3-(benzyloxy)phenyl)ethanol (2) (1.25 g, $5.78 \mathrm{mmol})$ to yield 2-(3-(benzyloxy)phenyl)acetaldehyde (789 mg, $3.49 \mathrm{mmol}$, 64\% yield) as a colourless oil. ${ }^{1} \mathrm{H}$ NMR $\left(400 \mathrm{MHz}, \mathrm{CDCl}_{3}\right) \delta: 9.73(\mathrm{t}, J=2.5 \mathrm{~Hz}, 1 \mathrm{H}), 7.41(\mathrm{tdd}, J=7.5,7.0,1.5$ $\mathrm{Hz}, 4 \mathrm{H}), 7.36-7.27(\mathrm{~m}, 1 \mathrm{H}), 6.95-6.90(\mathrm{~m}, 2 \mathrm{H}), 6.86-6.80(\mathrm{~m}, 2 \mathrm{H}), 5.07(\mathrm{~s}, 2 \mathrm{H}), 3.66(\mathrm{~d}, J=2.5 \mathrm{~Hz}$ 2H). No ionization found.

Benzyl (1-(diphenoxyphosphoryl)-2-phenylethyl)carbamate (10). Procedure and characterization consistent with previously reported data. ${ }^{49}$

Benzyl (1-(diphenoxyphosphoryl)-2-(p-tolyl)ethyl)carbamate (11). General procedure C with 2-( $p$ tolyl)acetaldehyde (3) (580 $\mathrm{mg}, 4.32 \mathrm{mmol})$, to give benzyl (1-(diphenoxyphosphoryl)-2-( $p$ tolyl)ethyl)carbamate (1.18 g, $2.36 \mathrm{mmol}, 55 \%$ yield) as an off-white solid. ${ }^{1} \mathrm{H} \mathrm{NMR}\left(400 \mathrm{MHz}, \mathrm{CDCl}_{3}\right)$ $\delta: 7.36-7.26(\mathrm{~m}, 5 \mathrm{H}), 7.26-7.20(\mathrm{~m}, 7 \mathrm{H}), 7.15(\mathrm{dd}, \mathrm{J}=16.0,8.0 \mathrm{~Hz}, 4 \mathrm{H}), 7.08(\mathrm{~d}, J=8.0 \mathrm{~Hz}, 5 \mathrm{H})$, $5.32-5.10(\mathrm{~m}, 5 \mathrm{H}), 5.09-4.87(\mathrm{~m}, 1 \mathrm{H}), 4.87-4.73(\mathrm{~m}, 2 \mathrm{H}), 3.38(\mathrm{ddd}, J=14.5,10.0,4.5 \mathrm{~Hz}, 1 \mathrm{H})$, 3.09 - $2.86(\mathrm{~m}, 1 \mathrm{H}), 2.32(\mathrm{~s}, 3 \mathrm{H}) .{ }^{13} \mathrm{C} \mathrm{NMR}\left(100 \mathrm{MHz}, \mathrm{CDCl}_{3}\right) \delta: 155.7,150.3,150.1,136.7,136.3$, $132.8,130.0,129.8,129.4,129.3,128.6,128.2,128.1,125.6,125.4,120.8,120.6,7.2,49.5$ (d, $\left.J_{\mathrm{CP}}=158.0 \mathrm{~Hz}\right), 35.7,21.25 . \mathrm{MS}(\mathrm{ESI}) \mathrm{m} / z$ 502.1 $[\mathrm{M}+\mathrm{H}]^{+} . \mathrm{MP}=114-116^{\circ} \mathrm{C}$

Benzyl (1-(diphenoxyphosphoryl)-2-(4-methoxyphenyl)ethyl)carbamate (12). General procedure C with 2-(4-methoxyphenyl)acetaldehyde (4) (269 $\mathrm{mg}, \quad 1.19 \mathrm{mmol})$ to yield benzyl (1(diphenoxyphosphoryl)-2-(4-methoxyphenyl) ethyl)carbamate (354 mg, $0.68 \mathrm{mmol}, 34 \%$ yield). ${ }^{1} \mathrm{H}$ NMR (400 MHz, $\left.\mathrm{CDCl}_{3}\right) \delta: 7.43-6.94(\mathrm{~m}, 17 \mathrm{H}), 6.81(\mathrm{~d}, J=8.5 \mathrm{~Hz}, 2 \mathrm{H}), 5.18(\mathrm{~d}, J=10.5 \mathrm{~Hz}, 1 \mathrm{H})$, $5.11-4.86(\mathrm{~m}, 2 \mathrm{H}), 4.76(\mathrm{dtd}, J=15.0,10.5,4.5 \mathrm{~Hz}, 1 \mathrm{H}), 3.78(\mathrm{~s}, 3 \mathrm{H}), 3.35$ (ddd, $J=14.5,10.0,4.5$ 
$1 \mathrm{~Hz}, 1 \mathrm{H}), 2.98(\mathrm{dt}, J=14.5,10.0 \mathrm{~Hz}, 1 \mathrm{H}) .{ }^{13} \mathrm{C} \mathrm{NMR}\left(100 \mathrm{MHz}, \mathrm{CDCl}_{3}\right) \delta: 158.7,155.7,150.3,150.1$,

$136.2,130.5,130.0,129.8,128.6,128.3,128.1,127.9,127.8,125.6,125.4,120.8,120.8,120.6,120.5$, 114.1, 67.3, 55.3, 49.5 (d, $\left.J_{\mathrm{CP}}=157.5 \mathrm{~Hz}\right), 35.3 . \mathrm{MS}(\mathrm{ESI}) \mathrm{m} / z 518.2[\mathrm{M}+\mathrm{H}]^{+}$.

Benzyl (benzofuran-5-yl(diphenoxyphosphoryl)methyl)carbamate (13). General procedure $\mathbf{C}$ with 1-benzofuran-5-carbaldehyde $\quad(500 \mathrm{mg}, \quad 3.42 \mathrm{mmol})$ to yield benzyl (benzofuran-5yl(diphenoxyphosphoryl)methyl)carbamate (100 mg, $0.95 \mathrm{mmol}, 6 \%$ yield). ${ }^{1} \mathrm{H}$ NMR $(400 \mathrm{MHz}$, $\left.\mathrm{CDCl}_{3}\right) \delta: 7.30-6.73(\mathrm{~m}, 20 \mathrm{H}), 5.88(\mathrm{br} \mathrm{s}, 1 \mathrm{H}), 5.62(\mathrm{~m}, 1 \mathrm{H}), 5.10(\mathrm{~m}, 2 \mathrm{H}) . \mathrm{MS}(\mathrm{ESI}) \mathrm{m} / z 536.0$ $[\mathrm{M}+\mathrm{Na}]^{+}$.

Benzyl (1-(diphenoxyphosphoryl)-2-(naphthalen-2-yl)ethyl)carbamate (14). General procedure C with 2-(naphthalen-1-yl)acetaldehyde (5) $\quad(56 \quad \mathrm{mg}, \quad 0.33 \quad \mathrm{mmol})$ to give benzyl (1(diphenoxyphosphoryl)-2-(naphthalen-2-yl)ethyl)carbamate (51 mg, $0.10 \mathrm{mmol}, 29 \%$ yield). ${ }^{1} \mathrm{H}$ NMR $\left(400 \mathrm{MHz}, \mathrm{CDCl}_{3}\right) \delta: 8.10-8.03(\mathrm{~m}, 1 \mathrm{H}), 7.88(\mathrm{dd}, J=6.5,3.0 \mathrm{~Hz}, 1 \mathrm{H}), 7.78(\mathrm{~d}, J=8.0 \mathrm{~Hz}, 1 \mathrm{H}), 7.56$ $-7.47(\mathrm{~m}, 2 \mathrm{H}), 7.42-6.99(\mathrm{~m}, 17 \mathrm{H}), 5.75(\mathrm{~d}, J=10.5 \mathrm{~Hz}, 1 \mathrm{H}), 5.08-4.87(\mathrm{~m}, 3 \mathrm{H}), 3.95(\mathrm{ddd}, \mathrm{J}=14.5$, 8.0, $4.0 \mathrm{~Hz}, 1 \mathrm{H}), 3.44(\mathrm{dt}, J=14.5,10.5 \mathrm{~Hz}, 1 \mathrm{H}) .{ }^{13} \mathrm{C} \mathrm{NMR}\left(100 \mathrm{MHz}, \mathrm{CDCl}_{3}\right) \delta: 155.8,150.4,150.1$, 136.2, 134.0, 132.0, 130.0, 129.8, 129.1, 128.5, 128.1, 128.0, 127.9, 127.8, 126.6, 125.8, 125.6, 125.3, 123.2, 120.7, 120.5, 67.0, $49.1\left(\mathrm{~d}, J_{\mathrm{CP}}=158.5 \mathrm{~Hz}\right), 33.12 . \mathrm{MS}(\mathrm{ESI}) \mathrm{m} / z 538.1[\mathrm{M}+\mathrm{H}]^{+}$.

Benzyl (1-(diphenoxyphosphoryl)-2-(4-fluorophenyl)ethyl)carbamate (15). General procedure C with 2-(4-fluorophenyl)acetaldehyde $\quad(6) \quad(545 \quad \mathrm{mg}, \quad 3.95 \mathrm{mmol}), \quad$ to give benzyl (1(diphenoxyphosphoryl)-2-(4-fluorophenyl)ethyl)carbamate (1.39 g, $2.75 \mathrm{mmol}, 70 \%$ yield) as an offwhite solid. ${ }^{1} \mathrm{H}$ NMR (400 MHz, $\left.\mathrm{CDCl}_{3}\right) \delta: 7.51-7.01(\mathrm{~m}, 17 \mathrm{H}), 6.87(\mathrm{dt}, J=17.0,8.0 \mathrm{~Hz}, 2 \mathrm{H}), 5.30$ $(\mathrm{d}, J=10.5 \mathrm{~Hz}, 1 \mathrm{H}), 5.17-4.85(\mathrm{~m}, 2 \mathrm{H}), 4.75(\mathrm{dtd}, J=15.0,10.5,4.5 \mathrm{~Hz}, 1 \mathrm{H}), 3.37(\mathrm{ddd}, J=14.0$ 9.0, 4.5 Hz, 1H), $3.00(\mathrm{dt}, J=14.5,10.0 \mathrm{~Hz}, 1 \mathrm{H}) .{ }^{13} \mathrm{C} \mathrm{NMR}\left(100 \mathrm{MHz}, \mathrm{CDCl}_{3}\right) \delta: 162.1,155.8,150.3$, $150.0,136.2,131.0,130.9,130.0,129.9,128.6,128.4,128.1,125.7,125.5,120.8,120.7,120.5,120.5$, $115.7,115.5,67.4,49.4\left(\mathrm{~d}, J_{\mathrm{CP}}=158.5 \mathrm{~Hz}\right), 35.4 . \mathrm{MS}(\mathrm{ESI}) \mathrm{m} / z 506.2[\mathrm{M}+\mathrm{H}]^{+} . \mathrm{MP}=133-135^{\circ} \mathrm{C}$

Benzyl (1-(diphenoxyphosphoryl)-2-(4-(trifluoromethyl)phenyl)ethyl) carbamate (16). General procedure $\mathbf{C}$ with 2-(4-(trifluoromethyl)phenyl)acetaldehyde (7) $(111 \mathrm{mg}, 0.59 \mathrm{mmol})$ to give benzyl (1-(diphenoxyphosphoryl)-2-(4-(trifluoromethyl) phenyl)ethyl)carbamate (91 mg, 0,16 mmol, 28\% yield) as an off-white solid. ${ }^{1} \mathrm{H}$ NMR (400 MHz, DMSO- $\left.d_{6}\right) \delta: 8.24(\mathrm{~d}, J=9.5 \mathrm{~Hz}, 1 \mathrm{H}), 7.66(\mathrm{~d}$, 
$J=8.0 \mathrm{~Hz}, 2 \mathrm{H}), 7.56(\mathrm{~d}, J=8.0 \mathrm{~Hz}, 2 \mathrm{H}), 7.45-7.34(\mathrm{~m}, 4 \mathrm{H}), 7.30-7.09(\mathrm{~m}, 11 \mathrm{H}), 4.95(\mathrm{~m}, 2 \mathrm{H}), 4.66$ $-4.51(\mathrm{~m}, 1 \mathrm{H}), 3.43-3.36(\mathrm{~m}, 1 \mathrm{H}), 3.10(\mathrm{~m}, 1 \mathrm{H}) .{ }^{13} \mathrm{C}$ NMR $\left(101 \mathrm{MHz}, \mathrm{DMSO}-d_{6}\right) \delta: 155.9,150.1$, $149.8,142.1,137.0,130.1,130.0,129.9,128.3,127.8,127.3,127.1\left(\mathrm{q}, J_{\mathrm{CF}}=31.5 \mathrm{~Hz}\right), 125.5,125.3$, $125.1\left(\mathrm{q}, J_{\mathrm{CF}}=3.5 \mathrm{~Hz}\right), 124.5\left(\mathrm{q}, J_{\mathrm{CF}}=272.0 \mathrm{~Hz}\right), 120.7,120.7,120.5,120.4,65.6,49.6(\mathrm{~d}$, $\left.J_{\mathrm{CP}}=159.5 \mathrm{~Hz}\right), 34.0 . \mathrm{MS}(\mathrm{ESI}) \mathrm{m} / z 556.0[\mathrm{M}+\mathrm{Na}]^{+},(95 \%)$. HRMS: Calc: 556.15 Found: 556.1481 $[\mathrm{M}+\mathrm{H}]^{+}$.

Benzyl (1-(diphenoxyphosphoryl)-3-(methylthio)propyl)carbamate (17). Procedure and characterization consistent with previously reported data. ${ }^{50}$

Benzyl ((diphenoxyphosphoryl)(6-hydroxynaphthalen-2-yl)methyl)carbamate (18). General procedure $\mathbf{C}$ with 6-hydroxy-2-naphthaldehyde $(289 \mathrm{mg}, 1.68 \mathrm{mmol})$, to give benzyl ((diphenoxyphosphoryl)(6-hydroxynaphthalen-2-yl)methyl)carbamate $\quad(208 \mathrm{mg}, \quad 0.39 \quad \mathrm{mmol}$, $23 \%$ yield) as a white solid. ${ }^{1} \mathrm{H}$ NMR $\left(400 \mathrm{MHz}, \mathrm{DMSO}-d_{6}\right) \delta: 9.85(\mathrm{~s}, 1 \mathrm{H}), 8.98(\mathrm{~d}, J=10.0 \mathrm{~Hz}, 1 \mathrm{H})$, $8.00(\mathrm{~s}, 1 \mathrm{H}), 7.78-7.63(\mathrm{~m}, 3 \mathrm{H}), 7.42-7.26(\mathrm{~m}, 9 \mathrm{H}), 7.21-7.05(\mathrm{~m}, 6 \mathrm{H}), 6.98(\mathrm{~d}, \mathrm{~J}=8.4 \mathrm{~Hz}, 2 \mathrm{H})$ $5.78-5.59(\mathrm{~m}, 1 \mathrm{H}), 5.10(\mathrm{dd}, J=35.0,12.5 \mathrm{~Hz}, 2 \mathrm{H}) .{ }^{13} \mathrm{C}$ NMR $\left(100 \mathrm{MHz}, \mathrm{DMSO}-d_{6}\right) \delta: 156.9,150.9$, $137.6,135.2,130.8,130.4,129.3,128.9,128.5,128.2,127.4,127.2,126.2,121.3,120.1,109.5,67.1$, $53.9\left(\mathrm{~d}, J_{\mathrm{CP}}=157.5 \mathrm{~Hz}\right) . \mathrm{MS}(\mathrm{ESI}) \mathrm{m} / z 540.1[\mathrm{M}+\mathrm{H}]^{+}$. HRMS: Calc: 540.16 Found: $540.1584[\mathrm{M}+\mathrm{H}]^{+}$. $\mathrm{MP}=166-168^{\circ} \mathrm{C}$

Benzyl (2-(4-(benzyloxy)phenyl)-1-(diphenoxyphosphoryl)ethyl)carbamate (19) General procedure $\mathbf{C}$ with 2-(4-(benzyloxy)phenyl)acetaldehyde (8) (1.79 g, $7.89 \mathrm{mmol})$, to give benzyl (2-(4(benzyloxy)phenyl)-1-(diphenoxyphosphoryl)ethyl) carbamate (3.55 g, $5.99 \mathrm{mmol}, 76 \%$ yield). ${ }^{1} \mathrm{H}$ NMR (400 MHz, $\left.\mathrm{CDCl}_{3}\right) \delta: 7.46-7.27(\mathrm{~m}, 12 \mathrm{H}), 7.25-7.02(\mathrm{~m}, 10 \mathrm{H}), 6.89(\mathrm{~d}, J=8.5 \mathrm{~Hz}, 2 \mathrm{H}), 5.22$ (d, $J=10.5 \mathrm{~Hz}, 1 \mathrm{H}), 5.03(\mathrm{~s}, 2 \mathrm{H}), 5.02(\mathrm{~s}, 2 \mathrm{H}), 4.83-4.70(\mathrm{~m}, 1 \mathrm{H}), 3.35$ (ddd, $J=14.5,10.0,4.5 \mathrm{~Hz}$, $1 \mathrm{H}), 2.99(\mathrm{dt}, J=14.5,10.0 \mathrm{~Hz}, 1 \mathrm{H}) .{ }^{13} \mathrm{C} \mathrm{NMR}\left(100 \mathrm{MHz}, \mathrm{CDCl}_{3}\right) \delta: 158.0,155.8,150.3,150.1,137.1$, $136.2,130.5,130.0,129.7,128.7,128.6,128.3,128.1,127.6,125.6,125.4,120.8,120.5,115.1,70.1$, 67.3, 49.6 (d, $\left.J_{\mathrm{CP}}=157.5 \mathrm{~Hz}\right), 35.3$. MS (ESI) $\mathrm{m} / z 594.2[\mathrm{M}+\mathrm{H}]^{+}$.

Benzyl (2-(3-(benzyloxy)phenyl)-1-(diphenoxyphosphoryl)ethyl)carbamate (20). General procedure $\mathbf{C}$ with 2-(3-(benzyloxy)phenyl)acetaldehyde (9) $(789 \mathrm{mg}, 3.49 \mathrm{mmol})$, to give benzyl (2-(3(benzyloxy)phenyl)-1-(diphenoxyphosphoryl)ethyl) carbamate $\left(1.37 \mathrm{~g}, 2.31 \mathrm{mmol}, 66 \%\right.$ yield). ${ }^{1} \mathrm{H}$ 
NMR (400 MHz, $\left.\mathrm{CDCl}_{3}\right) \delta: 7.48-7.06(\mathrm{~m}, 21 \mathrm{H}), 6.96-6.85(\mathrm{~m}, 3 \mathrm{H}), 5.33(\mathrm{~d}, J=10.5 \mathrm{~Hz}, 1 \mathrm{H}), 5.06$ (s, 2H), $5.00(\mathrm{~s}, 2 \mathrm{H}), 4.89-4.74(\mathrm{~m}, 1 \mathrm{H}), 3.46-3.36(\mathrm{~m}, 1 \mathrm{H}), 3.13-3.01(\mathrm{~m}, 1 \mathrm{H})$. MS (ESI) m/z 594.2 $[\mathrm{M}+\mathrm{H}]^{+}$.

Benzyl (1-(diphenoxyphosphoryl)-2-(4-hydroxyphenyl)ethyl)carbamate (21). General procedure D with benzyl (2-(4-(benzyloxy)phenyl)-1-(diphenoxyphosphoryl)ethyl)carbamate (19) (200 mg, 0.34 mmol) to yield benzyl (1-(diphenoxyphosphoryl)-2-(4-hydroxyphenyl)ethyl)carbamate (52 mg, 0.10 mmol, $31 \%$ yield) as a white solid. ${ }^{1} \mathrm{H}$ NMR $\left(400 \mathrm{MHz}, \mathrm{DMSO}-d_{6}\right) \delta: 9.33(\mathrm{~s}, 1 \mathrm{H}), 8.17(\mathrm{~d}, J=9.5 \mathrm{~Hz}$, 1H), $7.48-7.09(\mathrm{~m}, 18 \mathrm{H}), 6.73(\mathrm{t}, J=5.5 \mathrm{~Hz}, 2 \mathrm{H}), 5.08-4.94(\mathrm{~m}, 2 \mathrm{H}), 4.53-4.38(\mathrm{~m}, 1 \mathrm{H}), 3.19(\mathrm{dt}$, $J=14.0,3.5 \mathrm{~Hz}, 1 \mathrm{H}), 2.98-2.85(\mathrm{~m}, 1 \mathrm{H}) .{ }^{13} \mathrm{C}$ NMR (100 MHz, DMSO-d 6$) \delta: 157.0,151.1,150.7$, $137.9,131.0,130.8,129.2,128.6,128.1,126.3,126.2,121.6,121.3,116.0,66.3,51.2\left(\mathrm{~d}, J_{\mathrm{CP}}=156.0\right.$ $\mathrm{Hz})$, 34.1. MS (ESI) $\mathrm{m} / \mathrm{z} 504.2[\mathrm{M}+\mathrm{H}]^{+} . \mathrm{MP}=172-174{ }^{\circ} \mathrm{C}$

Benzyl (1-(diphenoxyphosphoryl)-2-(3-hydroxyphenyl)ethyl)carbamate (22). General procedure D with benzyl (2-(3-(benzyloxy)phenyl)-1-(diphenoxyphosphoryl) ethyl)carbamate (20) (500 mg, 0.84 mmol), to yield benzyl (1-(diphenoxyphosphoryl)-2-(3-hydroxyphenyl)ethyl)carbamate (196 mg, $0.39 \mathrm{mmol}, 46 \%$ yield) as a white solid. ${ }^{1} \mathrm{H}$ NMR (400 MHz, Acetone- $\left.d_{6}\right) \delta: 8.33(\mathrm{~s}, 1 \mathrm{H}), 7.50-7.20$ (m, 14H), $7.16(\mathrm{t}, J=8.0 \mathrm{~Hz}, 1 \mathrm{H}), 7.09(\mathrm{~d}, J=10.0 \mathrm{~Hz}, 1 \mathrm{H}), 6.96-6.84(\mathrm{~m}, 2 \mathrm{H}), 6.78(\mathrm{dd}, J=8.0,2.0$ $\mathrm{Hz}, 1 \mathrm{H}), 5.05(\mathrm{~s}, 2 \mathrm{H}), 4.76(\mathrm{dddd}, J=13.5,12.0,10.0,3.5 \mathrm{~Hz}, 1 \mathrm{H}), 3.40(\mathrm{ddd}, J=14.0,5.0,3.5 \mathrm{~Hz}$, 1H), 3.09 (ddd, $J=14.0,12.0,8.5 \mathrm{~Hz}, 1 \mathrm{H}) .{ }^{13} \mathrm{C}$ NMR (100 MHz, Acetone- $\left.d_{6}\right) \delta: 158.0,156.6,151.4$, $151.14,139.2,137.8,130.2,129.9,128.9,128.2,128.0,125.8,125.6,121.4,121.1,120.9,116.7,114.3$, 66.6, $50.8\left(\mathrm{~d}, J_{\mathrm{CP}}=158.5 \mathrm{~Hz}\right), 35.6 . \mathrm{MS}(\mathrm{ESI}) \mathrm{m} / z 504.2[\mathrm{M}+\mathrm{H}]^{+} . \mathrm{MP}=140-142{ }^{\circ} \mathrm{C}$

\section{Benzyl (1-((4-acetamidobenzyl)(4-acetamidophenoxy)phosphoryl)-2-phenylethyl) carbamate} (23). General procedure $\mathbf{C}$ with phenylethanal $(0.31 \mathrm{~mL}, 2.65 \mathrm{mmol})$ and tris(4-acetamidophenyl) phosphite (1.40 g, $2.91 \mathrm{mmol}, 1.1 \mathrm{eq})$ to give benzyl (1-(bis(4-acetamidophenoxy)phosphoryl)-2phenylethyl)carbamate (368 mg, $0.61 \mathrm{mmol}, 23 \%$ yield). ${ }^{1} \mathrm{H}$ NMR (400 MHz, DMSO- $\left.d_{6}\right) \delta: 10.00$ (d, $J=3.0 \mathrm{~Hz}, 2 \mathrm{H}), 8.15(\mathrm{~d}, J=9.5 \mathrm{~Hz}, 1 \mathrm{H}), 7.61-7.50(\mathrm{~m}, 4 \mathrm{H}), 7.39-7.20(\mathrm{~m}, 8 \mathrm{H}), 7.19-7.05(\mathrm{~m}, 6 \mathrm{H})$, $5.01-4.77(\mathrm{~m}, 2 \mathrm{H}), 4.47(\mathrm{tdd}, J=14.5,9.5,3.0 \mathrm{~Hz}, 1 \mathrm{H}), 3.25(\mathrm{dt}, J=7.5,3.5 \mathrm{~Hz}, 1 \mathrm{H}), 2.98$ (ddd, $J=13.5,12.5,8.0 \mathrm{~Hz}, 1 \mathrm{H}), 2.03(\mathrm{~s}, 6 \mathrm{H}) .{ }^{13} \mathrm{C}$ NMR $\left(100 \mathrm{MHz}, \mathrm{DMSO}-d_{6}\right) \delta: 168.9,155.9,145.2,145.0$, 
$137.2,136.5,129.1,128.2,127.6,127.2,126.6,120.8,120.5,120.1,65.9,49.8\left(\mathrm{~d}, J_{\mathrm{CP}}=157.5 \mathrm{~Hz}\right)$, 34.1, 23.9. MS (ESI) $m / z 602.2[\mathrm{M}+\mathrm{H}]^{+}$. HRMS: Calc: 602.21 Found: $602.2054[\mathrm{M}+\mathrm{H}]^{+}$.

Benzyl (1-(hydroxy(phenoxy)phosphoryl)-2-(4-hydroxyphenyl)ethyl)carbamate (24). KOH (58 mg, $0.99 \mathrm{mmol}, 3 \mathrm{eq})$ was added to a solution of benzyl (1-(diphenoxyphosphoryl)-2-(4hydroxyphenyl)ethyl)carbamate (21) (250 mg, $0.50 \mathrm{mmol})$ in $\mathrm{H}_{2} \mathrm{O}(5 \mathrm{~mL})$ and 1,4-dioxane (5 mL) and the resulting mixture was stirred at $\mathrm{rt}$ over $16 \mathrm{~h}$. The crude reaction was evaporated and $\mathrm{HCl}(1 \mathrm{~N}$ aq. sol.) was added to form the $\mathrm{HCl}$ salt. The residue was purified by reverse column chromatography (C18, $\mathrm{MeOH}$ in $\mathrm{H}_{2} \mathrm{O}$ 0/100 to 100/0). The desired fractions were then collected and evaporated to yield benzyl (1-(hydroxy(phenoxy)phosphoryl)-2-(4-hydroxyphenyl)ethyl)carbamate hydrochloride (47 mg, 0.10 mmol, $20 \%$ yield). ${ }^{1} \mathrm{H}$ NMR (400 MHz, Methanol- $\left.d_{4}\right) \delta: 7.38$ - 7.27 (m, 5H), 7.25 - 7.15 (m, 5H), 7.10 $(\mathrm{d}, J=8.5 \mathrm{~Hz}, 2 \mathrm{H}), 6.76-6.66(\mathrm{~m}, 2 \mathrm{H}), 5.10-4.91(\mathrm{~m}, 2 \mathrm{H}), 4.32(\mathrm{dd}, J=20.0,7.5 \mathrm{~Hz}, 1 \mathrm{H}), 3.26-3.16$ (m, 1H), 2.89 - $2.77(\mathrm{~m}, 1 \mathrm{H}) .{ }^{13} \mathrm{C}$ NMR (100 MHz, Methanol- $\left.d_{4}\right) \delta: 157.2,155.8,150.9,136.9,129.9$, 129.3, 128.0, 127.4, 127.0, 124.4, 120.4, 114.8, 66.1, $50.4\left(\mathrm{~d}, J_{\mathrm{CP}}=155.0 \mathrm{~Hz}\right), 34.2 . \mathrm{MS}(\mathrm{ESI}) \mathrm{m} / z 428.2$ $[\mathrm{M}+\mathrm{H}]^{+}$.

\section{Benzyl (2-(4-hydroxyphenyl)-1-(methoxy(phenoxy)phosphoryl)ethyl)carbamate (25). $\mathrm{NH}_{3}(7 \mathrm{~N}$ in} $\mathrm{MeOH})(0.09 \mathrm{~mL}, 0.60 \mathrm{mmol})$ was added to the stirred solution of benzyl (1-(diphenoxyphosphoryl)2-(4-hydroxyphenyl)ethyl)carbamate (21) $(200 \mathrm{mg}, 0.40 \mathrm{mmol})$ and $\mathrm{NH}_{4} \mathrm{Cl}(32 \mathrm{mg}, 0.60 \mathrm{mmol})$ in $\mathrm{MeOH}(4 \mathrm{~mL})$. The reaction mixture was stirred at $\mathrm{rt}$ and for 3 days. The reaction mixture was concentrated and purified by reverse column chromatography $\left(\mathrm{C} 18, \mathrm{MeOH}\right.$ in $\mathrm{H}_{2} \mathrm{O}, 0 / 100$ to 100/0). The desired fractions were then collected and evaporated to yield benzyl (2-(4-hydroxyphenyl)-1(methoxy(phenoxy)phosphoryl)ethyl)carbamate ( $26 \mathrm{mg}, 0.06 \mathrm{mmol}, 15 \%$ yield) as a colourless oil. ${ }^{1} \mathrm{H}$ NMR (400 MHz, Methanol- $\left.d_{4}\right) \delta: 7.73(\mathrm{dd}, J=9.5,6.0 \mathrm{~Hz}, 1 \mathrm{H}), 7.41-7.32(\mathrm{~m}, 2 \mathrm{H}), 7.32$ - $7.24(\mathrm{~m}$, 3H), $7.24-7.13(\mathrm{~m}, 5 \mathrm{H}), 7.12-6.96(\mathrm{~m}, 2 \mathrm{H}), 6.71(\mathrm{dd}, J=8.5,3.5 \mathrm{~Hz}, 2 \mathrm{H}), 4.99(\mathrm{ddd}, J=33.0,12.5$, $7.5 \mathrm{~Hz}, 2 \mathrm{H}), 4.52-4.31(\mathrm{~m}, 1 \mathrm{H}), 3.91-3.72(\mathrm{~m}, 3 \mathrm{H}), 3.23-3.09(\mathrm{~m}, 1 \mathrm{H}), 2.91-2.71(\mathrm{~m}, 1 \mathrm{H}) .{ }^{13} \mathrm{C}$ NMR (100 MHz, Methanol- $\left.d_{4}\right) \delta: 158.3,157.4,151.7,138.2,131.1,130.9,129.4,128.8,128.4,126.4$, 121.57, 116.3, 67.5, 54.7, $51.1\left(\mathrm{~d}, J_{\mathrm{CP}}=158.0\right), 35.3 . \mathrm{MS}(\mathrm{ESI}) \mathrm{m} / \mathrm{z} 442.1[\mathrm{M}+\mathrm{H}]^{+}$.

(S)-2-(((Benzyloxy)carbonyl)amino)-3-phenylpropanoic acid (26). Procedure and characterization consistent with previously reported data. ${ }^{51}$ 
1 (S)-Benzyl (1-amino-3-(4-hydroxyphenyl)-1-oxopropan-2-yl)carbamate (27). General procedure E 2 with ((benzyloxy)carbonyl)tyrosine $(382 \mathrm{mg}, 1.23 \mathrm{mmol})$ to yield (S)-benzyl (1-amino-3-(4hydroxyphenyl)-1-oxopropan-2-yl)carbamate (140 mg, $0.45 \mathrm{mmol}, 37 \%$ yield). MS (ESI) $\mathrm{m} / \mathrm{z} 315.1$ $[\mathrm{M}+\mathrm{H}]^{+}$.

(S)-Benzyl (1-amino-1-oxo-3-phenylpropan-2-yl)carbamate (28). General procedure $\mathbf{E}$ with $(S)$-2(((benzyloxy)carbonyl)amino)-3-phenylpropanoic acid (26) $(100 \mathrm{mg}, 0.33 \mathrm{mmol})$ to yield (S)-benzyl (1-amino-1-oxo-3-phenylpropan-2-yl)carbamate (98 mg, $0.33 \mathrm{mmol}$, 98\% yield). MS (ESI) $\mathrm{m} / \mathrm{z} 299.1$ $[\mathrm{M}+\mathrm{H}]^{+}$.

Benzyl (S)-(1-cyano-2-(4-hydroxyphenyl)ethyl)carbamate (29). General procedure F with (S)benzyl (1-amino-3-(4-hydroxyphenyl)-1-oxopropan-2-yl)carbamate (27) (140 mg, $0.45 \mathrm{mmol}$ ) to yield (S)-benzyl (1-cyano-2-(4-hydroxyphenyl)ethyl)carbamate (113 mg, $0.38 \mathrm{mmol}, 86 \%$ yield). ${ }^{1} \mathrm{H}$ NMR (400 MHz, Acetone- $\left.d_{6}\right) \delta: 8.33(\mathrm{~s}, 1 \mathrm{H}), 7.48$ - $7.32(\mathrm{~m}, 5 \mathrm{H}), 7.25$ - $7.18(\mathrm{~m}, 2 \mathrm{H}), 6.89$ - $6.78(\mathrm{~m}, 2 \mathrm{H})$, $5.13(\mathrm{~m}, 2 \mathrm{H}), 4.88-4.74(\mathrm{~m}, 1 \mathrm{H}), 3.15(\mathrm{~d}, J=7.5 \mathrm{~Hz}, 2 \mathrm{H}) .{ }^{13} \mathrm{C}$ NMR $\left(100 \mathrm{MHz}\right.$, Acetone- $\left.d_{6}\right) \delta: 158.3$, 157.0, 138.4, 132.2, 130.0, 129.6, 129.5, 127.8, 120.5, 117.0, 116.9, 68.0, 46.2, 39.3. MS (ESI) $\mathrm{m} / \mathrm{z}$ $297.1[\mathrm{M}+\mathrm{H}]^{+}$.

Benzyl (S)-(1-cyano-2-phenylethyl)carbamate (30). General procedure F with (S)-benzyl (1-amino1-oxo-3-phenylpropan-2-yl)carbamate (28) (460 mg, $1.54 \mathrm{mmol})$ to yield $(S)$ - benzyl (1-cyano-2phenylethyl)carbamate (323 mg, $1.15 \mathrm{mmol}, 75 \%$ yield). ${ }^{1} \mathrm{H}$ NMR (400 MHz, Acetone- $\left.d_{6}\right) \delta: 7.43$ $7.25(\mathrm{~m}, 10 \mathrm{H}), 5.13(\mathrm{~s}, 2 \mathrm{H}), 4.90(\mathrm{dt}, J=8.0,5.5 \mathrm{~Hz}, 1 \mathrm{H}), 3.30-3.20(\mathrm{~m}, 2 \mathrm{H}) .{ }^{13} \mathrm{C}$ NMR $(100 \mathrm{MHz}$ Acetone- $\left.d_{6}\right) \delta: 157.0,138.4,137.2,131.1,130.2,130.0,129.6,129.5,128.9,120.4,68.1,45.9,40.0$. MS (ESI) $m / z 281.1[\mathrm{M}+\mathrm{H}]^{+} . \mathrm{MP}=132-134{ }^{\circ} \mathrm{C}$. Characterization consistent with previously reported data. $^{52}$

Diphenyl (1-amino-2-(4-hydroxyphenyl)ethyl)phosphonate hydrobromide (31). Benzyl (2-(4(benzyloxy)phenyl)-1-(diphenoxyphosphoryl)ethyl)carbamate (19) (1.00 g, $1.69 \mathrm{mmol})$ ) was dissolved in $\mathrm{AcOH}(2 \mathrm{~mL})$ and then, $33 \% \mathrm{HBr} / \mathrm{AcOH}$ solution $(1.22 \mathrm{~mL}, 6.74 \mathrm{mmol}, 4 \mathrm{eq})$. The reaction was performed at $\mathrm{rt}$ for $6 \mathrm{~h}$. Then, the reaction mixture was concentrated in vacuo. The crude was purified by reverse phase column chromatography $\left(\mathrm{C} 18, \mathrm{MeOH}\right.$ in $\mathrm{H}_{2} \mathrm{O} 0 / 100$ to 60/40). The desired fractions were collected and concentrated to yield diphenyl (1-amino-2-(4-hydroxyphenyl)ethyl)phosphonate 
1 hydrobromide (374 mg, 49\% yield). ${ }^{1} \mathrm{H}$ NMR (400 MHz, DMSO- $\left.d_{6}\right) \delta: 7.41-7.35$ (m, 4H), 7.26 - 7.16 $(\mathrm{m}, 6 \mathrm{H}), 7.11(\mathrm{~d}, J=8.5 \mathrm{~Hz}, 2 \mathrm{H}), 6.70(\mathrm{~d}, J=8.5 \mathrm{~Hz}, 2 \mathrm{H}), 3.49(\mathrm{td}, J=10.0,3.5 \mathrm{~Hz}, 1 \mathrm{H}), 3.16-3.07$ (m, 1H), $2.70(\mathrm{dt}, J=14.0,10.5 \mathrm{~Hz}, 1 \mathrm{H}) . \mathrm{MS}(\mathrm{ESI}) \mathrm{m} / z 369.2[\mathrm{M}+\mathrm{H}]^{+}$.

\section{Benzyl \\ ((2S)-1-((1-(diphenoxyphosphoryl)-2-(4-hydroxyphenyl)ethyl)amino)-4-methyl-1-} oxopentan-2-yl)carbamate (32). To a stirred solution of $N$-carbobenzyloxy-L-leucine (71 mg, 0.27 mmol, $1.2 \mathrm{eq}$ ) in MeCN (3 mL) and DMF (1 mL), 1-hydroxybenzotriazolehydrate (37 mg, $0.24 \mathrm{mmol}$, $1.1 \mathrm{eq})$ and $N, N^{\prime}$-dicyclohexylcarbodiimide ( $\left.92 \mathrm{mg}, 0.44 \mathrm{mmol}, 2 \mathrm{eq}\right)$ were added and the solution was stirred for $10 \mathrm{~min}$ at rt. Then, a solution of diphenyl (1-amino-2-(4-hydroxyphenyl)ethyl)phosphonate hydrobromide (31) $(100 \mathrm{mg}, 0.22 \mathrm{mmol})$ and $\mathrm{Et}_{3} \mathrm{~N}(0.03 \mathrm{~mL}, 0.22 \mathrm{mmol}, 1 \mathrm{eq})$ in $\mathrm{DCM}(2 \mathrm{~mL})$ at $0{ }^{\circ} \mathrm{C}$ and the mixture was left stirring at $\mathrm{rt}$ for $16 \mathrm{~h}$. Then, the precipitate was filtrated off. The solvent was evaporated in vacuo from the filtrate and the crude was purified by flash column chromatography $\left(\mathrm{SiO}_{2}\right.$, EtOAc in heptane $0 / 100$ to $100 / 0)$ to yield benzyl ((2S)-1-((1-(diphenoxyphosphoryl)-2-(4hydroxyphenyl)ethyl)amino)-4-methyl-1-oxopentan-2-yl)carbamate (32) (24 mg, 18\% yield) as a colourless oil. ${ }^{1} \mathrm{H}$ NMR (400 MHz, $\left.\mathrm{CDCl}_{3}\right) \delta: 7.39-7.28(\mathrm{~m}, 12 \mathrm{H}), 7.23-7.12(\mathrm{~m}, 7 \mathrm{H}), 7.06(\mathrm{~d}$, $J=8.0 \mathrm{~Hz}, 2 \mathrm{H}), 5.28(\mathrm{~d}, J=8.5 \mathrm{~Hz}, 1 \mathrm{H}), 5.14(\mathrm{~s}, 2 \mathrm{H}), 4.62(\mathrm{td}, J=9.0,4.5 \mathrm{~Hz}, 1 \mathrm{H}), 3.62(\mathrm{td}, J=10.5$, $3.0 \mathrm{~Hz}, 1 \mathrm{H}), 3.47-3.37(\mathrm{~m}, 1 \mathrm{H}), 2.93(\mathrm{dt}, J=14.0,10.5 \mathrm{~Hz}, 1 \mathrm{H}), 1.87-1.77(\mathrm{~m}, 2 \mathrm{H}), 1.73-1.65(\mathrm{~m}$, 1H), $1.03-1.00(\mathrm{~m}, 6 \mathrm{H}) .{ }^{13} \mathrm{C} \mathrm{NMR}\left(100 \mathrm{MHz}, \mathrm{CDCl}_{3}\right) \delta: 172.0,156.1,150.4,149.5,136.2,135.3$, $130.5,129.9,128.7,128.4,128.3,125.4,121.7,120.7,67.3,52.8,50.7\left(\mathrm{~d}, J_{\mathrm{CP}}=157.5 \mathrm{~Hz}\right), 41.7,37.2$, 25.0, 23.0, 22.0. MS (ESI) $\mathrm{m} / \mathrm{z} 617.3[\mathrm{M}+\mathrm{H}]^{+}$.

Tert-butyl (1-(diphenoxyphosphoryl)-3-(methylthio)propyl)carbamate (33). General procedure C with 4-thiapentanal $(4.40 \mathrm{~g}, 42.20 \mathrm{mmol})$ and $O$-tert-butylcarbamate $(4.95 \mathrm{~g}, 42.20 \mathrm{mmol})$ to give tertbutyl (1-(diphenoxyphosphoryl)-3-(methylthio)propyl)carbamate (5.480 g, $12.53 \mathrm{mmol}, 30 \%$ yield). MS (ESI) $m / z 438.2[\mathrm{M}+\mathrm{H}]^{+}$.

Diphenyl (1-amino-3-(methylthio)propyl)phosphonate hydrochloride (34). General procedure G with tert-butyl (1-(diphenoxyphosphoryl)-3-(methylthio)propyl)carbamate (33) (500 mg, $1.14 \mathrm{mmol}$ ) to yield diphenyl (1-amino-3-(methylthio)propyl)phosphonate hydrochloride (425 mg, 1.14 mmol, 99\% yield). MS (ESI) $\mathrm{m} / z 338.2[\mathrm{M}+\mathrm{H}]^{+}$. 


\section{Benzyl tert-butyl ((5S)-6-((1-(diphenoxyphosphoryl)-3-(methylthio)propyl)amino)-6-oxohexane-} 1,5-diyl)dicarbamate (35). To a stirred solution of (R)-2-(((benzyloxy)carbonyl)amino)-6-((tertbutoxycarbonyl)amino)hexanoic acid (122 $\mathrm{mg}, 0.32 \mathrm{mmol})$ in $\mathrm{MeCN}(3 \mathrm{~mL})$ and DMF (1 mL), 1hydroxybenzotriazolehydrate $\quad(53 \quad \mathrm{mg}, \quad 0.35 \quad \mathrm{mmol})$ and $N$-Ethyl- $N^{\prime}-(3-$ dimethylaminopropyl)carbodiimide hydrochloride $(62 \mathrm{mg}, 0.32 \mathrm{mmol})$ were added and the solution was stirred for $10 \mathrm{~min}$ at rt. Then, a solution of diphenyl (1-amino-3-(methylthio)propyl)phosphonate hydrochloride (34) (100 mg, $0.27 \mathrm{mmol})$ and $\mathrm{Et}_{3} \mathrm{~N}(0.08 \mathrm{~mL}, 0.59 \mathrm{mmol})$ in $\mathrm{MeCN}(3 \mathrm{~mL})$ was added at $0{ }^{\circ} \mathrm{C}$ and the mixture was left stirring at $\mathrm{rt}$ for $16 \mathrm{~h}$. Then, the precipitate was filtrated off. The solvent was evaporated in vacuo from the filtrate and the crude was purified by flash column chromatography $\left(\mathrm{SiO}_{2}\right.$, EtOAc in heptane 0/100 to 100/0). Desired fractions were collected and concentrated to yield benzyl tert-butyl ((5S)-6-((1-(diphenoxyphosphoryl)-3-(methylthio)propyl)amino)-6-oxohexane-1,5diyl)dicarbamate (35) (220 mg, $0.252 \mathrm{mmol}, 94 \%$ yield). MS (ESI) $\mathrm{m} / z, 700.4[\mathrm{M}+\mathrm{H}]^{+}$.

Benzyl ((2S)-6-amino-1-((1-(diphenoxyphosphoryl)-3-(methylthio)propyl)amino)-1-oxohexan-2yl)carbamate hydrochloride (36). General procedure $\mathbf{G}$ with benzyl tert-butyl ((5S)-6-((1(diphenoxyphosphoryl)-3-(methylthio)propyl)amino)-6-oxohexane-1,5-diyl)dicarbamate (250 mg, $0.36 \mathrm{mmol}) \quad$ to yield benzyl ((2S)-6-amino-1-((1-(diphenoxyphosphoryl)-3(methylthio)propyl)amino)-1-oxohexan-2-yl)carbamate hydrochloride (36) (123 mg, 0.19 mmol, 54\% yield) as a colourless oil. ${ }^{1} \mathrm{H}$ NMR (400 MHz, Methanol- $\left.d_{4}\right) \delta: 7.52-7.05(\mathrm{~m}, 15 \mathrm{H}), 5.20-4.93(\mathrm{~m}$, 3H), $4.32-4.08(\mathrm{~m}, 1 \mathrm{H}), 2.95-2.74(\mathrm{~m}, 2 \mathrm{H}), 2.74-2.38(\mathrm{~m}, 2 \mathrm{H}), 2.37-2.12(\mathrm{~m}, 2 \mathrm{H}), 2.11-1.98(\mathrm{~m}$,

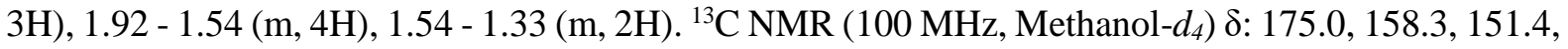
$138.1,131.1,130.9,129.5,129.1,128.9,126.8,121.8,121.6,67.7,56.3,46.3\left(\mathrm{~d}, J_{\mathrm{CP}}=160.0 \mathrm{~Hz}\right), 40.4$, 32.6, 31.1, 29.5, 28.1, 23.7, 15.3. MS (ESI) $\mathrm{m} / z 600.3[\mathrm{M}+\mathrm{H}]^{+}$.

(S)-2-((Tert-butoxycarbonyl)amino)-3-(4-hydroxyphenyl)propanoic $\quad$ acid $\quad(37) . \quad$ Di-tertbutyldicarbonate $(1.21 \mathrm{~g}, 5.52 \mathrm{mmol})$ was added to a solution of $(S)$-(-)-Tyrosine $(1.00 \mathrm{~g}, 5.52 \mathrm{mmol})$ in a mixture of dioxane $(5 \mathrm{~mL}), \mathrm{H}_{2} \mathrm{O}(2.5 \mathrm{~mL})$ and $\mathrm{NaOH}(1 \mathrm{M}, 5 \mathrm{~mL})$ at $0{ }^{\circ} \mathrm{C}$ and the above mixture and stirred for $6 \mathrm{~h}$ at $\mathrm{rt}$. Then the solution was concentrated in vacuum, cooled in an ice water bath, covered with a layer of EtOAc and acidified with a dilute solution of $\mathrm{KHSO}_{4}$ such that the solution $\mathrm{pH}$ 2-3. The aqueous phase was extracted with EtOAc, dried $\left(\mathrm{Na}_{2} \mathrm{SO}_{4}\right)$, filtered and solvents and evaporated 
in vacuo to yield $(S)$-2-((tert-butoxycarbonyl)amino)-3-(4-hydroxyphenyl)propanoic acid (1.55 $\mathrm{g}$, $5.16 \mathrm{mmol}, 94 \%$ yield). MS (ESI) $\mathrm{m} / z 304.2[\mathrm{M}+\mathrm{Na}]^{+}$.

Tert-butyl (S)-(1-amino-3-(4-hydroxyphenyl)-1-oxopropan-2-yl)carbamate $\quad(38) . \quad$ General procedure $\mathbf{E}$ with (S)-2-((tert-butoxycarbonyl)amino)-3-(4-hydroxyphenyl)propanoic acid (37) (1.00 g, $3.55 \mathrm{mmol}$ ) to yield (S)-tert-butyl (1-amino-3-(4-hydroxyphenyl)-1-oxopropan-2-yl)carbamate (1.09 g, $3.51 \mathrm{mmol}, 99 \%$ yield). ${ }^{1} \mathrm{H}$ NMR (400 MHz, DMSO- $\left.d_{6}\right) \delta: 9.13(\mathrm{~s}, 1 \mathrm{H}), 7.02(\mathrm{~d}, J=8.5 \mathrm{~Hz}, 2 \mathrm{H}), 6.64$ $(\mathrm{d}, J=8.5 \mathrm{~Hz}, 2 \mathrm{H}), 3.98(\mathrm{dd}, J=9.5,5.0 \mathrm{~Hz}, 1 \mathrm{H}), 2.82(\mathrm{dd}, J=14.0,4.5 \mathrm{~Hz}, 1 \mathrm{H}), 2.61(\mathrm{dd}, J=14.0$, $10.0 \mathrm{~Hz}, 1 \mathrm{H}), 1.36-1.26(\mathrm{~m}, 9 \mathrm{H}) . \mathrm{MS}(\mathrm{ESI}) \mathrm{m} / \mathrm{z} 303.2[\mathrm{M}+\mathrm{Na}]^{+}$.

(S)-2-Amino-3-(4-hydroxyphenyl)propanamide hydrochloride (39). General procedure $\mathbf{G}$ with $(S)$ tert-butyl (1-amino-3-(4-hydroxyphenyl)-1-oxopropan-2-yl)carbamate (38) (1.09 g, $3.90 \mathrm{mmol})$ to yield (S)-2-amino-3-(4-hydroxyphenyl)propanamide hydrochloride (804 mg, $3.71 \mathrm{mmol}, 95 \%$ yield). ${ }^{1} \mathrm{H}$ NMR (400 MHz, Methanol- $\left.d_{4}\right) \delta: 7.18-7.11(\mathrm{~m}, 2 \mathrm{H}), 6.82-6.74(\mathrm{~m}, 2 \mathrm{H}), 4.06(\mathrm{dd}, J=8.0,6.0 \mathrm{~Hz}$, 1H), $3.16(\mathrm{dd}, J=14.0,6.0 \mathrm{~Hz}, 1 \mathrm{H}), 2.98(\mathrm{dd}, J=14.0,8.0 \mathrm{~Hz}, 1 \mathrm{H}) . \mathrm{MS}(\mathrm{ESI}) \mathrm{m} / z 181.1[\mathrm{M}+\mathrm{H}]^{+}$.

Benzyl

((S)-1-(((S)-1-amino-3-(4-hydroxyphenyl)-1-oxopropan-2-yl)amino)-4-methyl-1oxopentan-2-yl)carbamate (40). A solution of (S)-2-amino-3-(4-hydroxyphenyl)propanamide hydrochloride (39) (804 mg, $3.71 \mathrm{mmol})$ and $N, N$-diisopropylethylamine $(0.65 \mathrm{~mL}, 3.71 \mathrm{mmol})$ in DCM (1 mL) was added dropwise to a solution of Z-Leu-OSu (1.61 g, $4.45 \mathrm{mmol})$ in DCM (10 mL) at $0{ }^{\circ} \mathrm{C}$. The reaction mixture was stirred at $\mathrm{rt}$ for $16 \mathrm{~h}$. The mixture was concentrated, dissolved in EtOAc, washed with $\mathrm{NaHCO}_{3}$ sat. and $\mathrm{HCl}(1 \mathrm{M})$, dried $\left(\mathrm{Na}_{2} \mathrm{SO}_{4}\right)$, filtered and solvents concentrated in vacuo to yield benzyl ((S)-1-(((S)-1-amino-3-(4-hydroxyphenyl)-1-oxopropan-2-yl)amino)-4-methyl-1oxopentan-2-yl)carbamate (608 mg, $1.34 \mathrm{mmol}, 36 \%$ yield). MS (ESI) $\mathrm{m} / z 428.3[\mathrm{M}+\mathrm{H}]^{+}$.

\section{Benzyl \\ ((S)-1-(((S)-1-cyano-2-(4-hydroxyphenyl)ethyl)amino)-4-methyl-1-oxopentan-2-} yl)carbamate (41). General procedure F with benzyl ((S)-1-(((S)-1-amino-3-(4-hydroxyphenyl)-1oxopropan-2-yl)amino)-4-methyl-1-oxopentan-2-yl)carbamate (40) (508 mg, $1.19 \mathrm{mmol})$ to yield benzyl ((S)-1-(((S)-1-cyano-2-(4-hydroxyphenyl)ethyl)amino)-4-methyl-1-oxopentan-2-yl)carbamate (137 mg, $0.34 \mathrm{mmol}, 28 \%$ yield). ${ }^{1} \mathrm{H}$ NMR (400 MHz, Acetone- $\left.d_{6}\right) \delta: 8.32(\mathrm{~s}, 1 \mathrm{H}), 8.04(\mathrm{~d}, J=8.0 \mathrm{~Hz}$, 1H), $7.60-7.26(\mathrm{~m}, 5 \mathrm{H}), 7.17(\mathrm{~d}, J=8.5 \mathrm{~Hz}, 2 \mathrm{H}), 6.79(\mathrm{~d}, J=8.5 \mathrm{~Hz}, 2 \mathrm{H}), 6.43(\mathrm{~m}, 1 \mathrm{H}), 5.08(\mathrm{q}$, $J=12.5 \mathrm{~Hz}, 2 \mathrm{H}), 4.99(\mathrm{dt}, J=7.5,5.5 \mathrm{~Hz}, 1 \mathrm{H}), 4.22(\mathrm{dd}, J=14.5,8.5 \mathrm{~Hz}, 1 \mathrm{H}), 3.05(\mathrm{~d}, J=7.5 \mathrm{~Hz}$ 
$12 \mathrm{H}), 1.78-1.63(\mathrm{~m}, 1 \mathrm{H}), 1.63-1.40(\mathrm{~m}, 2 \mathrm{H}), 0.89(\mathrm{dd}, J=9.0,6.5 \mathrm{~Hz}, 6 \mathrm{H}) .{ }^{13} \mathrm{C} \mathrm{NMR}(100 \mathrm{MHz}$,

Acetone- $\left.d_{6}\right) \delta: 173.0,157.6,157.1,138.1,131.5,129.2,128.7,126.9,119.4,116.2,66.9,54.3,43.0$ 41.7, 38.26, 25.3, 23.3, 21.8. MS (ESI) $m / z, 410.1[\mathrm{M}+\mathrm{H}]^{+}$.

Diphenyl ((1-carbamimidoylpiperidin-4-yl)(2-(4-methoxyphenyl)acetamido)methyl)phosphonate 2,2,2-trifluoroacetate (42). ${ }^{1} \mathrm{H}$ NMR $\left(400 \mathrm{MHz}\right.$, Methanol- $\left.d_{4}\right) \delta: 7.33$ (dt, $\left.J=16.0,8.0 \mathrm{~Hz}, 4 \mathrm{H}\right), 7.27-$ $7.18(\mathrm{~m}, 4 \mathrm{H}), 7.14-7.07(\mathrm{~m}, 2 \mathrm{H}), 7.02(\mathrm{dd}, J=7.5,1.0 \mathrm{~Hz}, 2 \mathrm{H}), 6.87-6.79(\mathrm{~m}, 2 \mathrm{H}), 4.77(\mathrm{dd}, J=18.5$, $6.5 \mathrm{~Hz}, 1 \mathrm{H}), 3.90(\mathrm{t}, J=14.5 \mathrm{~Hz}, 2 \mathrm{H}), 3.74(\mathrm{~s}, 3 \mathrm{H}), 3.54(\mathrm{~s}, 2 \mathrm{H}), 3.19-3.02(\mathrm{~m}, 2 \mathrm{H}), 2.39(\mathrm{ddd}, J=18.5$, 9.5, $5.5 \mathrm{~Hz}, 1 \mathrm{H}), 2.04(\mathrm{~d}, J=13.0 \mathrm{~Hz}, 2 \mathrm{H}), 1.49(\mathrm{qd}, J=13.0,4.0 \mathrm{~Hz}, 2 \mathrm{H}) . \mathrm{MS}(\mathrm{ESI}) \mathrm{m} / z 537.0[\mathrm{M}+\mathrm{H}]^{+}$. Synthetic procedures in the supporting information.

Diphenyl ((1-carbamimidoylpiperidin-4-yl)(nicotinamido)methyl)phosphonate trifluoroacetate (43). ${ }^{1} \mathrm{H}$ NMR $\left(400 \mathrm{MHz}\right.$, Methanol- $\left.d_{4}\right) \delta$ : 8.6-5.73 (m, 2H), $8.14(\mathrm{~d}, J=8.0 \mathrm{~Hz}, 1 \mathrm{H})$, $7.56(\mathrm{~d}, J=4.5 \mathrm{~Hz}, 1 \mathrm{H}), 7.42-7.28(\mathrm{~m}, 4 \mathrm{H}), 7.25-7.15(\mathrm{~m}, 6 \mathrm{H}), 5.02(\mathrm{dd}, J=17.5,8.0 \mathrm{~Hz}, 1 \mathrm{H}), 3.96$ (d, $J=13.5 \mathrm{~Hz}, 2 \mathrm{H}), 3.17(\mathrm{ddd}, J=21.5,14.0,2.5 \mathrm{~Hz}, 2 \mathrm{H}), 2.54(\mathrm{ddd}, J=11.5,8.0,3.5 \mathrm{~Hz}, 2 \mathrm{H}), 2.27$ $(\mathrm{d}, J=13.0 \mathrm{~Hz}, 1 \mathrm{H}), 2.09(\mathrm{~d}, J=13.5 \mathrm{~Hz}, 1 \mathrm{H}), 1.76-1.46(\mathrm{~m}, 2 \mathrm{H}) . \mathrm{MS}(\mathrm{ESI}) \mathrm{m} / z 494.0[\mathrm{M}+\mathrm{H}]^{+}$. Synthetic procedures in the supporting information.

Diphenyl ((1-carbamimidoylpiperidin-4-yl)(furan-2-carboxamido)methyl)phosphonate 2,2,2trifluoroacetate (44). ${ }^{1} \mathrm{H}$ NMR (400 MHz, Methanol- $\left.d_{4}\right) \delta: 7.72(\mathrm{dd}, J=1.5,0.5 \mathrm{~Hz}, 1 \mathrm{H}), 7.45-7.27$ (m, 4H), $7.26-7.07(\mathrm{~m}, 7 \mathrm{H}), 6.62(\mathrm{dd}, J=3.5,1.5 \mathrm{~Hz}, 1 \mathrm{H}), 3.94(\mathrm{~d}, J=13.5 \mathrm{~Hz}, 2 \mathrm{H}), 3.15(\mathrm{td}, J=15.5$, $2.5 \mathrm{~Hz}, 2 \mathrm{H}), 2.52(\mathrm{ddd}, \mathrm{J}=16.0,9.5,6.0 \mathrm{~Hz}, 1 \mathrm{H}), 2.26(\mathrm{~d}, J=13.0 \mathrm{~Hz}, 1 \mathrm{H}), 2.08(\mathrm{~d}, J=13.5 \mathrm{~Hz}, 1 \mathrm{H})$ $1.72-1.39(\mathrm{~m}, 2 \mathrm{H})$. MS (ESI) $\mathrm{m} / z 483.0[\mathrm{M}+\mathrm{H}]^{+}$. Synthetic procedures in the supporting information. Diphenyl ((1-carbamimidoylpiperidin-4-yl)(cinnamamido)methyl)phosphonate bis(2,2,2trifluoroacetate) (45). ${ }^{1} \mathrm{H}$ NMR $\left(400 \mathrm{MHz}\right.$, Methanol- $\left.d_{4}\right) \delta: 7.62(\mathrm{~d}, J=15.5 \mathrm{~Hz}, 1 \mathrm{H}), 7.60$ - $7.55(\mathrm{~m}$, 2H), $7.46-7.31(\mathrm{~m}, 7 \mathrm{H}), 7.28-7.14(\mathrm{~m}, 6 \mathrm{H}), 6.74(\mathrm{~d}, J=15.5 \mathrm{~Hz}, 1 \mathrm{H}), 4.96(\mathrm{dd}, J=18.5,6.5 \mathrm{~Hz}, 1 \mathrm{H})$, $4.07-3.80(\mathrm{~m}, 2 \mathrm{H}), 3.16(\mathrm{td}, J=15.5,2.5 \mathrm{~Hz}, 2 \mathrm{H}), 2.45(\mathrm{ddd}, J=18.5,9.5,5.5 \mathrm{~Hz}, 1 \mathrm{H}), 2.12(\mathrm{dd}, J=$ 9.5, $4.0 \mathrm{~Hz}, 2 \mathrm{H}), 1.70-1.47(\mathrm{~m}, 2 \mathrm{H}) . \mathrm{MS}(\mathrm{ESI}) \mathrm{m} / z 519.3[\mathrm{M}+\mathrm{H}]^{+}$. Synthetic procedures in the supporting information.

Diphenyl ((1-carbamimidoylpiperidin-4-yl)(2-phenoxyethylsulfonamido)methyl)phosphonate 2,2,2-trifluoroacetate (46). ${ }^{1} \mathrm{H}$ NMR (400 MHz, Methanol- $\left.d_{4}\right) \delta$ : 7.35-7.30 (m, 4H), 7.25-7.17 (m, 6H), 
7.13-7.07 (m, 2H), 6.97-6.91 (m, 1H), 6.90-6.84 (m, 2H), $4.42(\mathrm{t}, J=6.5 \mathrm{~Hz}, 2 \mathrm{H}), 4.35(\mathrm{dd}, J=19.0$, $5.4 \mathrm{~Hz}, 1 \mathrm{H}), 3.98(\mathrm{dd}, J=10.5,3.5 \mathrm{~Hz}, 2 \mathrm{H}), 3.68(\mathrm{t}, J=6.5 \mathrm{~Hz}, 2 \mathrm{H}), 3.14(\mathrm{td}, J=15.0,2.5 \mathrm{~Hz}, 2 \mathrm{H})$, $2.52-2.34(\mathrm{~m}, 1 \mathrm{H}), 2.21-1.98(\mathrm{~m}, 2 \mathrm{H}), 1.87-1.56(\mathrm{~m}, 2 \mathrm{H}) . \mathrm{MS}(\mathrm{ESI}) \mathrm{m} / z 573.2[\mathrm{M}+\mathrm{H}]^{+}$. Synthetic procedures in the supporting information.

Diphenyl ((1-carbamimidoylpiperidin-4-yl)(3-(piperidin-4-yl)propanamido)methyl)phosphonate bis(2,2,2-trifluoroacetate) (47). ${ }^{1} \mathrm{H}$ NMR (400 MHz, Methanol- $\left.d_{4}\right) \delta: 7.44$ - 7.33 (m, 4H), 7.29 - 7.19 (m, 4H), $7.15-7.09(\mathrm{~m}, 2 \mathrm{H}), 4.82(\mathrm{dd}, J=18.0,7.0 \mathrm{~Hz}, 1 \mathrm{H}), 4.01-3.87(\mathrm{~m}, 2 \mathrm{H}), 3.28(\mathrm{~d}, J=2.5 \mathrm{~Hz}$ 2H), $3.14(\mathrm{td}, J=13.0,2.0 \mathrm{~Hz}, 2 \mathrm{H}), 2.84-2.70(\mathrm{~m}, 2 \mathrm{H}), 2.48-2.29(\mathrm{~m}, 3 \mathrm{H}), 2.16-2.02(\mathrm{~m}, 2 \mathrm{H}), 1.94$ - $1.82(\mathrm{~m}, 2 \mathrm{H}), 1.68-1.45(\mathrm{~m}, 5 \mathrm{H}), 1.41-1.25(\mathrm{~m}, 2 \mathrm{H})$. MS (ESI) $\mathrm{m} / z 528.3[\mathrm{M}+\mathrm{H}]^{+}$. Synthetic procedures in the supporting information.

Diphenyl (E)-diphenyl ((3-(benzo[d][1,3]dioxol-5-yl)acrylamido)(1-carbamimidoylpiperidin-4yl)methyl)phosphonate 2,2,2-trifluoroacetate (48). ${ }^{1} \mathrm{H}$ NMR $\left(400 \mathrm{MHz}\right.$, Methanol- $\left.d_{4}\right) \delta: 7.53$ (d, $J=15.5 \mathrm{~Hz}, 1 \mathrm{H}), 7.36(\mathrm{dd}, J=17.0,8.5 \mathrm{~Hz}, 4 \mathrm{H}), 7.28-7.10(\mathrm{~m}, 7 \mathrm{H}), 7.06(\mathrm{dd}, J=8.0,1.5 \mathrm{~Hz}, 1 \mathrm{H})$, $6.86(\mathrm{~d}, J=8.0 \mathrm{~Hz}, 1 \mathrm{H}), 6.55(\mathrm{~d}, J=15.5 \mathrm{~Hz}, 1 \mathrm{H}), 6.01(\mathrm{~s}, 2 \mathrm{H}), 5.04-4.90(\mathrm{~m}, 1 \mathrm{H}), 3.94(\mathrm{t}, J=11.0 \mathrm{~Hz}$, 2H), $3.16(\mathrm{dd}, J=24.0,13.0 \mathrm{~Hz}, 2 \mathrm{H}), 2.56-2.32(\mathrm{~m}, 1 \mathrm{H}), 2.20-1.99(\mathrm{~m}, 2 \mathrm{H}), 1.70-1.48(\mathrm{~m}, 2 \mathrm{H}) . \mathrm{MS}$ (ESI) $m / z 563.2[\mathrm{M}+\mathrm{H}]^{+}$. Synthetic procedures in the supporting information.

\section{Diphenyl ((3-(benzo[d][1,3]dioxol-5-yl)propiolamido)(1-carbamimidoylpiperidin-4-} yl)methyl)phosphonate (49). ${ }^{1} \mathrm{H}$ NMR $\left(400 \mathrm{MHz}\right.$, Methanol- $\left.d_{4}\right) \delta: 7.38(\mathrm{td}, J=8.0,3.0 \mathrm{~Hz}, 4 \mathrm{H}), 7.28$ - $7.12(\mathrm{~m}, 7 \mathrm{H}), 7.04(\mathrm{~d}, J=1.5 \mathrm{~Hz}, 1 \mathrm{H}), 6.89(\mathrm{~d}, J=8.0 \mathrm{~Hz}, 1 \mathrm{H}), 6.04(\mathrm{~s}, 2 \mathrm{H}), 4.01-3.88(\mathrm{~m}, 2 \mathrm{H}), 3.22$ - $3.06(\mathrm{~m}, 2 \mathrm{H}), 2.53-2.38(\mathrm{~m}, 1 \mathrm{H}), 2.12(\mathrm{t}, J=13.5 \mathrm{~Hz}, 2 \mathrm{H}), 1.69-1.48(\mathrm{~m}, 2 \mathrm{H})$. MS (ESI) $\mathrm{m} / z 561.2$ $[\mathrm{M}+\mathrm{H}]^{+}$. Synthetic procedures in the supporting information.

\section{Diphenyl ((1-carbamimidoylpiperidin-4-yl)((5-phenylpyrimidin-2-yl)amino)methyl)phosphonate} 2,2,2-trifluoroacetate (50). ${ }^{1} \mathrm{H}$ NMR (400 MHz, DMSO-d $\left.d_{6}\right) \delta: 8.79-8.59(\mathrm{~m}, 2 \mathrm{H}), 8.07$ (d, $J=10.0 \mathrm{~Hz}, 1 \mathrm{H}), 7.73-7.57(\mathrm{~m}, 2 \mathrm{H}), 7.53-7.43(\mathrm{~m}, 2 \mathrm{H}), 7.26-7.06(\mathrm{~m}, 5 \mathrm{H}), 5.11(\mathrm{ddd}, J=17.0$, $10.5,7.0 \mathrm{~Hz}, 1 \mathrm{H}), 7.36(\mathrm{dt}, J=12.5,4.0 \mathrm{~Hz}, 7 \mathrm{H}), 3.90(\mathrm{t}, J=15.0 \mathrm{~Hz}, 2 \mathrm{H}), 3.19-2.95(\mathrm{~m}, 2 \mathrm{H}), 2.49-$ $2.42(\mathrm{~m}, 1 \mathrm{H}), 2.00(\mathrm{t}, J=10.5 \mathrm{~Hz}, 2 \mathrm{H}), 1.65-1.39(\mathrm{~m}, 2 \mathrm{H}) . \mathrm{MS}(\mathrm{ESI}) \mathrm{m} / z 543.2[\mathrm{M}+\mathrm{H}]^{+}$. Synthetic procedures in the supporting information. 
1 (Z)-Diphenyl ((1-carbamimidoylpiperidin-4-yl)(3-phenylacrylamido)methyl)phosphonate 2,2,2-

2 trifluoroacetate (51). ${ }^{1} \mathrm{H}$ NMR (400 MHz, Methanol- $\left.d_{4}\right) \delta: 7.52(\mathrm{dd}, J=7.5,1.5 \mathrm{~Hz}, 2 \mathrm{H}), 7.36(\mathrm{t}$, $J=8.0 \mathrm{~Hz}, 4 \mathrm{H}), 7.27-7.18(\mathrm{~m}, 5 \mathrm{H}), 7.17-7.11(\mathrm{~m}, 4 \mathrm{H}), 6.87(\mathrm{~d}, J=12.5 \mathrm{~Hz}, 1 \mathrm{H}), 6.10(\mathrm{dd}, J=12.5$ $1.0 \mathrm{~Hz}, 1 \mathrm{H}), 4.92-4.88(\mathrm{~m}, 1 \mathrm{H}), 3.91(\mathrm{~d}, J=14.0 \mathrm{~Hz}, 2 \mathrm{H}), 3.20-3.00(\mathrm{~m}, 2 \mathrm{H}), 2.48-2.27(\mathrm{~m}, 1 \mathrm{H})$, $2.05(\mathrm{dd}, J=25.5,14.5 \mathrm{~Hz}, 2 \mathrm{H}), 1.65-1.36(\mathrm{~m}, 2 \mathrm{H}) . \mathrm{MS}(\mathrm{ESI}) \mathrm{m} / z 519.3[\mathrm{M}+\mathrm{H}]^{+}$. Synthetic procedures in the supporting information.

Methyl (1-(diphenoxyphosphoryl)-2-(4-guanidinophenyl)ethyl)carbamate (52). Procedure and characterization consistent with previously reported data. ${ }^{53}$

Diphenyl

(2-(4-guanidinophenyl)-1-((S)-2-((S)-3-hydroxy-2-(thiophene-2carboxamido)propanamido)propanamido)ethyl)phosphonate (53). ${ }^{1} \mathrm{H}$ NMR $\left(\mathrm{CDCl}_{3}\right) \delta: 7.8-7.1$ (m, 17H), $5.1(\mathrm{~m}, 1 \mathrm{H}), 4.2$ - $4.3(\mathrm{~m}, 2 \mathrm{H}), 3.9(\mathrm{~m}, 2 \mathrm{H}), 3.4(\mathrm{~m}, 2 \mathrm{H}), 1.3(\mathrm{~m}, 3 \mathrm{H}) . \mathrm{MS}(\mathrm{ESI}) \mathrm{m} / \mathrm{z} 679.3$ $[\mathrm{M}+\mathrm{H}]^{+},(100 \%)$. Procedure and characterization consistent with previously reported data. ${ }^{38}$

Pent-4-yn-1-yl (1-(diphenoxyphosphoryl)-2-(4-guanidinophenyl)ethyl)carbamate (54). Procedure and characterization consistent with previously reported data. ${ }^{54}$

2-(2-Azidoethoxy)ethyl (1-(diphenoxyphosphoryl)-2-(4-guanidinophenyl)ethyl)carbamate (55). Procedure and characterization consistent with previously reported data. ${ }^{54}$

(Perfluorophenyl)methyl (1-(diphenoxyphosphoryl)-2-(4-guanidinophenyl)ethyl)carbamate 2,2,2-trifluoroacetate (56). ${ }^{1} \mathrm{H}$ NMR (400 MHz, Methanol- $\left.d_{4}\right) \delta:$ 7.5-7.0 (m, 14H), $5.1(\mathrm{~m}, 2 \mathrm{H}), 4.60$ (m, 1H), $4.57(\mathrm{~m}, 1 \mathrm{H}), 3.4(\mathrm{~m}, 1 \mathrm{H}), 3.08(\mathrm{~m}, 1 \mathrm{H}) . \mathrm{MS}(\mathrm{ESI}) \mathrm{m} / \mathrm{z} 635.1[\mathrm{M}+\mathrm{H}]^{+}$. Synthetic procedures in the supporting information.

3,3,4,4,5,5,6,6,7,8,8,8-dodecafluoro-7-(trifluoromethyl)octyl

1-(diphenoxyphosphoryl)-2-(4guanidinophenyl)ethylcarbamate 2,2,2-trifluoroacetate (57). ${ }^{1} \mathrm{H} \mathrm{NMR}\left(400 \mathrm{MHz}, \mathrm{CDCl}_{3}\right) \delta: 10.02$ (s, 1H), 7.41-7.12 (m, 14H), $5.43(\mathrm{~m}, 1 \mathrm{H}), 4.69(\mathrm{~m}, 1 \mathrm{H}), 4.26(\mathrm{~m}, 2 \mathrm{H}), 3.38(\mathrm{~m}, 1 \mathrm{H}), 3.08(\mathrm{~m}, 1 \mathrm{H}), 2.35$ $(\mathrm{m}, 2 \mathrm{H}) . \mathrm{MS}(\mathrm{ESI}) \mathrm{m} / z 851.1[\mathrm{M}+\mathrm{H}]^{+}$. Synthetic procedures in the supporting information.

Benzyl ((4-aminophenyl)(diphenoxyphosphoryl)methyl)carbamate (58). ${ }^{1} \mathrm{H}$ NMR (400 MHz, DMSO- $\left.d_{6}\right) \delta: 8.82(\mathrm{~d}, J=10.0 \mathrm{~Hz}, 1 \mathrm{H}), 7.48(\mathrm{dd}, J=16.0,9.0 \mathrm{~Hz}, 2 \mathrm{H}), 7.42-7.26(\mathrm{~m}, 8 \mathrm{H}), 7.18(\mathrm{dd}$, $J=15.5,8.0 \mathrm{~Hz}, 2 \mathrm{H}), 7.09-7.02(\mathrm{~m}, 2 \mathrm{H}), 6.96(\mathrm{t}, J=8.0 \mathrm{~Hz}, 3 \mathrm{H}), 5.50(\mathrm{dd}, J=22.0,10.0 \mathrm{~Hz}, 1 \mathrm{H})$, $5.09(\mathrm{dd}, J=33.5,12.5 \mathrm{~Hz}, 2 \mathrm{H}) .{ }^{13} \mathrm{C} \mathrm{NMR}\left(100 \mathrm{MHz}, \mathrm{DMSO}-d_{6}\right) \delta: 156.0,155.9,150.1,149.8,136.6$, 
$131.0,129.83,129.78,129.6,129.5,128.3,127.9,125.3,125.2,120.4,120.35,120.29,120.2,118.3$, 66.1, $52.4\left(\mathrm{~d}, J_{\mathrm{CP}}=159.0 \mathrm{~Hz}\right)$. HRMS: Calc: 489.16 Found: $489.1588[\mathrm{M}+\mathrm{H}]^{+}$. Procedure and characterization consistent with previously reported data. ${ }^{55}$

2-Phenoxyethyl ((4-aminophenyl)(diphenoxyphosphoryl)methyl)carbamate (59). Procedure and characterization consistent with previously reported data. ${ }^{55}$

4,4,4-Trifluorobutyl ((4-aminophenyl)(diphenoxyphosphoryl)methyl)carbamate (60). Procedure and characterization consistent with previously reported data. ${ }^{55}$

(Perfluorophenyl)methyl ((4-aminophenyl)(diphenoxyphosphoryl)methyl)carbamate

(61). Procedure and characterization consistent with previously reported data. ${ }^{55}$

Diphenyl ((4-guanidinophenyl)((4-(trifluoromethyl)phenyl)sulfonamido)methyl)phosphonate (62). Procedure and characterization consistent with previously reported data. ${ }^{55}$

Diphenyl ((4-guanidinophenyl)(phenylsulfonamido)methyl)phosphonate (63). Procedure and characterization consistent with previously reported data. ${ }^{55}$

(Perfluorophenyl)methyl ((diphenoxyphosphoryl)(4-guanidinophenyl)methyl)carbamate (64). Procedure and characterization consistent with previously reported data. ${ }^{55}$

Methyl ((diphenoxyphosphoryl)(4-(2,2,2-trifluoroacetamido)phenyl)methyl)carbamate $(65) .{ }^{1} \mathrm{H}$ NMR (400 MHz, Methanol- $\left.d_{4}\right) \delta: 7.70(\mathrm{~m}, 1 \mathrm{H}), 7.55(\mathrm{~m}, 2 \mathrm{H}), 7.41-7.07(\mathrm{~m}, 10 \mathrm{H}), 5.6(\mathrm{~d}, 1 \mathrm{H}$, $J=20.0 \mathrm{~Hz}), 3,75(\mathrm{~s}, 3 \mathrm{H}) . \mathrm{MS}(\mathrm{ESI}) \mathrm{m} / \mathrm{z} 531.1[\mathrm{M}+\mathrm{Na}]^{+}$. Synthetic procedures in the supporting information.

Benzo[d][1,3]dioxol-5-ylmethyl

((diphenoxyphosphoryl)(4-(2,2,2-trifluoroacetamido) phenyl)methyl)carbamate (66). ${ }^{1} \mathrm{H}$ NMR $\left(400 \mathrm{MHz}\right.$, Methanol- $\left.d_{4}\right) \delta: 7.70-7.50(\mathrm{~m}, 4 \mathrm{H}), 7.40-6.80(\mathrm{~m}$, 13H), $5.80(\mathrm{~m}, 2 \mathrm{H}), 5.60(\mathrm{~d}, J=28.0 \mathrm{~Hz}, 1 \mathrm{H}), 4.90(\mathrm{~s}, 2 \mathrm{H}) .{ }^{13} \mathrm{C}$ NMR $\left(100 \mathrm{MHz}, \mathrm{DMSO}-d_{6}\right) \delta: 156.6$, $156.1,150.0,149.7,147.3,146.8,136.2,131.5,131.1,130.0,129.9,125.5,125.4,122.1,121.7,121.1$, $120.4,120.4,120.4,120.0,119.2-113.6\left(\mathrm{~m}, \mathrm{CF}_{3}\right), 108.5,108.1,101.4,100.8,66.1,52.4(\mathrm{~d}$, $\left.J_{\mathrm{CP}}=158.0 \mathrm{~Hz}\right) . \mathrm{MS}(\mathrm{ESI}) \mathrm{m} / \mathrm{z} 629.2[\mathrm{M}+\mathrm{H}]^{+},(96 \%)$. HRMS: Calc: 629.13 Found: $629.1301[\mathrm{M}+\mathrm{H}]^{+}$. Synthetic procedures in the supporting information.

2-Aminoethyl ((diphenoxyphosphoryl)(4-(2,2,2-trifluoroacetamido)phenyl)methyl)carbamate 2,2,2-trifluoroacetate (67). ${ }^{1} \mathrm{H}$ NMR (400 MHz, Methanol- $\left.d_{4}\right) \delta$ : 7.75-7.5 (m, 4H), 7.40-6.93 (m,10H), 
$15.72(\mathrm{~m}, 2 \mathrm{H}), 4.43(\mathrm{~m}, 2 \mathrm{H}), 3.44(\mathrm{~m}, 2 \mathrm{H}) . \mathrm{MS}(\mathrm{ESI}) \mathrm{m} / \mathrm{z} 538.2[\mathrm{M}-\mathrm{H}]^{-}$. Synthetic procedures in the

2 supporting information.

Benzyl 2-(4-(3,3-dimethylureido)phenyl)-1-(diphenoxyphosphoryl)ethylcarbamate (68). ${ }^{1} \mathrm{H}$ NMR $\left(400 \mathrm{MHz}, \mathrm{CDCl}_{3}\right) \delta: 7.05-7.38(\mathrm{~m}, 19 \mathrm{H}), 6.39(\mathrm{~s}, 1 \mathrm{H}), 5.34(\mathrm{~d}, \mathrm{~J}=10.5 \mathrm{~Hz}, 1 \mathrm{H}), 4.95-5.10(\mathrm{~m}$, 2H), $4.69-4.84(\mathrm{~m}, 1 \mathrm{H}), 3.36(\mathrm{ddd}, \mathrm{J}=4.5,10.0,14.5 \mathrm{~Hz}, 1 \mathrm{H}), 3.02(\mathrm{~s}, 6 \mathrm{H}), 1.28(\mathrm{~s}, 1 \mathrm{H}) . \mathrm{MS}(\mathrm{ESI})$ $m / z 574.7[\mathrm{M}+\mathrm{H}]^{+}$. Synthetic procedures in the supporting information.

\section{Benzyl ((4-(2-aminoethoxy)phenyl)(diphenoxyphosphoryl)methyl)carbamate} trifluoroacetate (69). ${ }^{1} \mathrm{H}$ NMR $\left(400 \mathrm{MHz}, \mathrm{CDCl}_{3}\right) \delta: 7.60-6.80(\mathrm{~m}, 19 \mathrm{H}), 5.58(\mathrm{~d}, J=22.5 \mathrm{~Hz}, 1 \mathrm{H})$, $5.15(\mathrm{~m}, 2 \mathrm{H}), 4.25(\mathrm{t}, J=5.0 \mathrm{~Hz}, 2 \mathrm{H}), 3.37(\mathrm{t}, J=5.0 \mathrm{~Hz}, 2 \mathrm{H})$. MS (ESI) $m / z 533.1[\mathrm{M}+\mathrm{H}]^{+}$. Synthetic procedures in the supporting information.

Benzyl (1-(diphenoxyphosphoryl)-3-(4-nitrophenyl)propyl)carbamate (70). General procedure C with 3-(4-nitrophenyl)propanal (420 mg, $2.34 \mathrm{mmol}$ ) to yield benzyl (1-(diphenoxyphosphoryl)-3-(4nitrophenyl)propyl)carbamate (700 mg, $1.28 \mathrm{mmol}, 55 \%$ yield). ${ }^{1} \mathrm{H}$ NMR (400 MHz, Acetone- $\left.d_{6}\right) \delta$ : $8.24-8.05(\mathrm{~m}, 2 \mathrm{H}), 7.57$ - $7.44(\mathrm{~m}, 2 \mathrm{H}), 7.44-7.27(\mathrm{~m}, 9 \mathrm{H}), 7.26$ - $7.05(\mathrm{~m}, 6 \mathrm{H}), 5.22$ - $5.08(\mathrm{~m}, 2 \mathrm{H})$, $4.58-4.25(\mathrm{~m}, 1 \mathrm{H}), 3.06$ (ddd, $J=14.0,9.0,5.0 \mathrm{~Hz}, 1 \mathrm{H}), 2.92(\mathrm{ddd}, J=24.0,15.0,11.0 \mathrm{~Hz}, 1 \mathrm{H}), 2.46$ - 2.17 (m, 2H). ${ }^{13} \mathrm{C}$ NMR (100 MHz, Acetone- $\left.d_{6}\right) \delta: 157.9,152.3,152.0,150.8,148.2,138.7,131.4$, $131.3,130.0,129.9,129.6,129.3,126.8,126.7,125.1,122.3,122.0,68.1,49.7\left(\mathrm{~d}, J_{\mathrm{CP}}=159.0 \mathrm{~Hz}\right)$, 33.2, 32.4. MS (ESI) m/z 547.1 [M+H] $]^{+},(100 \%)$. HRMS: Calc: 547.16 Found: $547.1646[\mathrm{M}+\mathrm{H}]^{+}$.

Methyl ((4-carbamimidoylphenyl)(diphenoxyphosphoryl)methyl)carbamate (71). ${ }^{1} \mathrm{H}$ NMR (400 MHz, DMSO-d $) \delta: 9.45(\mathrm{~s}, 2 \mathrm{H}), 9.22(\mathrm{~s}, 1 \mathrm{H}), 8.80(\mathrm{~d}, J=20.0 \mathrm{~Hz}, 1 \mathrm{H}), 7.90-7.85(\mathrm{~m}, 4 \mathrm{H}), 7.40-$ $7.36(\mathrm{~m}, 4 \mathrm{H}), 7.24-7.20(\mathrm{~m}, 2 \mathrm{H}), 7.10-7.00(\mathrm{~m}, 4 \mathrm{H}) 5.78-5.72(\mathrm{~m}, 1 \mathrm{H}), 3.61(\mathrm{~s}, 3 \mathrm{H}) .{ }^{13} \mathrm{C} \mathrm{NMR}$ $\left(100 \mathrm{MHz}, \mathrm{DMSO}-d_{6}\right) \delta: 165.4,156.7,149.9,149.6,140.5,130.1,128.9,127.9,125.4,120.4,120.38$, 120.32, 120.27, 120.23, 64.9, $52.3\left(\mathrm{~d}, J_{\mathrm{CP}}=157.5 \mathrm{~Hz}\right) . \mathrm{MS}(\mathrm{ESI}) \mathrm{m} / z 440.2[\mathrm{M}+\mathrm{H}]^{+},(100 \%) . \mathrm{HRMS}:$ Calc: 440.14 Found: $440.1369[\mathrm{M}+\mathrm{H}]^{+}$. Procedure and characterization consistent with previously reported data. ${ }^{53}$

Methyl ((diphenoxyphosphoryl)(5-nitronaphthalen-1-yl)methyl)carbamate $\quad$ (72). ${ }^{1} \mathrm{H} \quad \mathrm{NMR}$ $\left(400 \mathrm{MHz}, \mathrm{CDCl}_{3}\right) \delta: 8.62-8.51(\mathrm{~m}, 1 \mathrm{H}), 8.46-8.31(\mathrm{~m}, 1 \mathrm{H}), 8.24-8.17(\mathrm{~m}, 1 \mathrm{H}), 8.03-7.91(\mathrm{~m}, 1 \mathrm{H})$, 
$1 \quad 7.74-7.58(\mathrm{~m}, 2 \mathrm{H}), 7.35-7.01(\mathrm{~m}, 10 \mathrm{H}), 6.5-6.35(\mathrm{~m}, 1 \mathrm{H}), 6.11-6.01(\mathrm{~m}, 1 \mathrm{H})$. MS (ESI) $\mathrm{m} / z \quad 493.1$

$2 \quad[\mathrm{M}+\mathrm{H}]^{+}$. Synthetic procedures in the supporting information.

\section{Diphenyl ((1-carbamimidoylazetidin-3-yl)(pyrimidin-2-ylamino)methyl)phosphonate 2,2,2-} trifluoroacetate (73). ${ }^{1} \mathrm{H}$ NMR $\left(400 \mathrm{MHz}, \mathrm{DMSO}-d_{6}\right) \delta: 8.47-8.24(\mathrm{~m}, 2 \mathrm{H}), 8.08(\mathrm{~d}, J=9.5 \mathrm{~Hz}, 1 \mathrm{H})$, $7.37(\mathrm{td}, J=8.0,3.0 \mathrm{~Hz}, 4 \mathrm{H}), 7.29(\mathrm{~s}, 3 \mathrm{H}), 7.21(\mathrm{td}, J=7.5,3.5 \mathrm{~Hz}, 2 \mathrm{H}), 7.11(\mathrm{~d}, J=8.0 \mathrm{~Hz}, 3 \mathrm{H}), 6.73$ (t, $J=5.0 \mathrm{~Hz}, 1 \mathrm{H}), 5.37(\mathrm{dt}, J=15.5,9.5 \mathrm{~Hz}, 1 \mathrm{H}), 4.13-4.26(\mathrm{~m}, 2 \mathrm{H}), 4.07(\mathrm{ddd}, J=9.5,6.0,3.5 \mathrm{~Hz}$, 2H), 3.62-3.44 (m, 1H). MS (ESI) $\mathrm{m} / z 439.2[\mathrm{M}+\mathrm{H}]^{+}$. Synthetic procedures in the supporting information.

Diphenyl ((3-(N-hydroxycarbamimidoyl)phenyl)(pyrimidin-2-ylamino)methyl)phosphonate (74). ${ }^{1} \mathrm{H}$ NMR (400 MHz, DMSO-d $)$ ) 8.67 (s, 1H), 8.47 (dd, $\left.J=10.5,2.0 \mathrm{~Hz}, 1 \mathrm{H}\right), 8.37$ (d, $J=4.5 \mathrm{~Hz}$, $2 \mathrm{H}), 8.05(\mathrm{q}, J=2.0 \mathrm{~Hz}, 1 \mathrm{H}), 7.72-7.81(\mathrm{~m}, 1 \mathrm{H}), 7.66(\mathrm{dq}, J=8.0,1.5 \mathrm{~Hz}, 1 \mathrm{H}), 7.41(\mathrm{t}, J=8.0 \mathrm{~Hz}$, 1H), $7.29-7.36(\mathrm{~m}, 4 \mathrm{H}), 7.14-7.21(\mathrm{~m}, 2 \mathrm{H}), 7.04(\mathrm{dq}, J=7.8,1.2 \mathrm{~Hz}, 2 \mathrm{H}), 6.98(\mathrm{dq}, J=8.0,1.0 \mathrm{~Hz}$, 2H), $6.71(\mathrm{t}, J=5.0 \mathrm{~Hz}, 1 \mathrm{H}), 6.26(\mathrm{dd}, J=22.5,10.5 \mathrm{~Hz}, 1 \mathrm{H}), 5.82(\mathrm{~s}, 2 \mathrm{H})$. No ionization found. Synthetic procedures in the supporting information.

\section{2-(2-(Prop-2-yn-1-yloxy)ethoxy)ethyl}

(diphenoxyphosphoryl)(4-(piperazin-1yl)phenyl)methylcarbamate 2,2,2-trifluoroacetate (75). ${ }^{1} \mathrm{H}$ NMR $\left(400 \mathrm{MHz}, \mathrm{CDCl}_{3}\right) \delta: 7.42$ (dd, $J=8.5,1.5 \mathrm{~Hz}, 2 \mathrm{H}), 7.36-7.28(\mathrm{~m}, 2 \mathrm{H}), 7.26-7.16(\mathrm{~m}, 3 \mathrm{H}), 7.16-7.05(\mathrm{~m}, 3 \mathrm{H}), 6.96-6.78(\mathrm{~m}$, $4 \mathrm{H}), 6.25(\mathrm{~d}, J=9.5 \mathrm{~Hz}, 1 \mathrm{H}), 5.53(\mathrm{dd}, J=22.5,9.5 \mathrm{~Hz}, 1 \mathrm{H}), 4.22(\mathrm{~d}, J=2.5 \mathrm{~Hz}, 2 \mathrm{H}), 4.17(\mathrm{~d}, J=2.5$ $\mathrm{Hz}, 2 \mathrm{H}), 3.76-3.73(\mathrm{~m}, 2 \mathrm{H}), 3.71-3.60(\mathrm{~m}, 4 \mathrm{H}), 3.40-3.25(\mathrm{~m}, 4 \mathrm{H}), 3.03(\mathrm{~s}, 2 \mathrm{H}), 2.96-2.92(\mathrm{~m}$, 2H), $2.42(\mathrm{~s}, 1 \mathrm{H})$. MS (ESI) $\mathrm{m} / z 594.8[\mathrm{M}+\mathrm{H}]^{+}$. Synthetic procedures in the supporting information.

Benzyl (1-(diphenoxyphosphoryl)-4-guanidinobutyl)carbamate (76). Procedure and characterization consistent with previously reported data. ${ }^{56}$

Benzyl (benzo[d][1,3]dioxol-5-yl(diphenoxyphosphoryl)methyl)carbamate (77). Procedure and characterization consistent with previously reported data. ${ }^{46}$

Benzyl ((4-(dimethylamino)phenyl)(diphenoxyphosphoryl)methyl)carbamate (78). ${ }^{1} \mathrm{H}$ NMR (400 $\left.\mathrm{MHz}, \mathrm{CDCl}_{3}\right) \delta: 7.37-7.06(\mathrm{~m}, 15 \mathrm{H}), 6.88(\mathrm{~d}, J=9.0 \mathrm{~Hz}, 2 \mathrm{H}), 6.69(\mathrm{~d}, J=8.5 \mathrm{~Hz}, 2 \mathrm{H}), 5.72(\mathrm{~d}$, $J=8.0 \mathrm{~Hz}, 1 \mathrm{H}), 5.47(\mathrm{~m}, 1 \mathrm{H}), 5.09(\mathrm{~m}, 2 \mathrm{H}), 2.94(\mathrm{~s}, 6 \mathrm{H}, 2 \mathrm{CH} 3)$. MS (ESI) $m / z 517.3[\mathrm{M}+\mathrm{H}]^{+},(95 \%)$. 
1 HRMS: Calc: 517.19 Found: $517.1894[\mathrm{M}+\mathrm{H}]^{+}$. Procedure and characterization consistent with

2 previously reported data. ${ }^{46}$

Benzyl ((diphenoxyphosphoryl)(pyridin-3-yl)methyl)carbamate (79). Procedure and characterization consistent with previously reported data. ${ }^{57}$

Benzyl ((diphenoxyphosphoryl)(3-nitrophenyl)methyl)carbamate $\quad(80) . \quad$ Procedure and characterization consistent with previously reported data. ${ }^{58}$

Benzyl (1-(diphenoxyphosphoryl)ethyl)carbamate (81). Procedure and characterization consistent with previously reported data. ${ }^{49}$

Benzyl (1-(diphenoxyphosphoryl)-3-methylbutyl)carbamate (82). Procedure and characterization consistent with previously reported data. ${ }^{49}$

Benzyl ((diphenoxyphosphoryl)(4-guanidinophenyl)methyl)carbamate (83). Procedure and characterization consistent with previously reported data. ${ }^{55}$

Benzyl (2-(benzyloxy)-1-(diphenoxyphosphoryl)ethyl)carbamate (84). Procedure and characterization consistent with previously reported data. ${ }^{59}$

Benzyl ((3-aminophenyl)(diphenoxyphosphoryl)methyl)carbamate (85). ${ }^{1} \mathrm{H}$ NMR (400 MHz, $\left.\mathrm{CDCl}_{3}\right) \delta: 7.29-6.75(\mathrm{~m}, 19 \mathrm{H}), 6.54(\mathrm{~s}(\mathrm{~b}), 1 \mathrm{H}), 5.59(\mathrm{dd}, J=22.5,10.0 \mathrm{~Hz}, 1 \mathrm{H}), 5.05(\mathrm{dd}, J=53.0$, $12.2 \mathrm{~Hz}, 2 \mathrm{H}) .{ }^{13} \mathrm{C} \mathrm{NMR}\left(\mathrm{CDCl}_{3}\right) \delta: 155.6,150.1,146.5,136.0,135.2,129.8,129.7,128.6,128.3,128.2$, 125.4, 120.5, 118.6, 115.7, 115.0, 67.5, $52.9\left(\mathrm{~d}, J_{\mathrm{CP}}=159.5 \mathrm{~Hz}\right)$. MS (ESI) $m / z 489.2[\mathrm{M}+\mathrm{H}]^{+},(95 \%)$. HRMS: Calc: 489.16 Found: $489.1582[\mathrm{M}+\mathrm{H}]^{+}$. Procedure and characterization consistent with previously reported data. ${ }^{58}$

Benzyl ((diphenoxyphosphoryl)(6-methoxypyridin-2-yl)methyl)carbamate (86). General procedure C with 6-methoxypicolinaldehyde $(200 \mathrm{mg}, 1.46 \mathrm{mmol})$ to give benzyl (diphenoxyphosphoryl)(6-methoxypyridin-2-yl)methylcarbamate (298 mg, $0.59 \mathrm{mmol}, 41 \%$ yield). ${ }^{1} \mathrm{H}$ NMR (400 MHz, $\left.\mathrm{CDCl}_{3}\right) \delta: 7.57(\mathrm{dd}, J=25.0,18.0 \mathrm{~Hz}, 1 \mathrm{H}), 7.51-7.21(\mathrm{~m}, 8 \mathrm{H}), 7.19-6.92(\mathrm{~m}, 6 \mathrm{H})$, $6.75(\mathrm{br} \mathrm{s}, 1 \mathrm{H}), 6.36(\mathrm{~m}, 1 \mathrm{H}), 5.72(\mathrm{~d}, J=13.0 \mathrm{~Hz}, 2 \mathrm{H}), 5.19(\mathrm{dd}, J=37.0,12.0 \mathrm{~Hz}, 2 \mathrm{H}), 3.88(\mathrm{~s}, 3 \mathrm{H})$. ${ }^{13} \mathrm{C}$ NMR $\left(100 \mathrm{MHz}, \mathrm{CDCl}_{3}\right) \delta: 163.6,155.7,150.5,150.4,150.3,150.2,149.6,139.4,136.1,129.7$, 129.6, 128.7, 128.6, 128.3, 125.3, 125.2, 120.5, 120.3, 116.4, 111.0, 67.5, 56.3 (d, $J=156.5 \mathrm{~Hz}), 53.6$. MS (ESI) $m / z$ 505.6 [M+H] $]^{+},(100 \%)$. HRMS: Calc: 505.15 Found: $505.1506[\mathrm{M}+\mathrm{H}]^{+}$. 
1 Benzyl ((2-chloro-5-nitrophenyl)(diphenoxyphosphoryl)methyl)carbamate (87). Procedure and

2 characterization consistent with previously reported data. ${ }^{60}$

Benzyl ((4-carbamimidoylphenyl)(diphenoxyphosphoryl)methyl)carbamate (88). Procedure and characterization consistent with previously reported data. ${ }^{53}$

Benzyl ((5-chloro-1H-indol-3-yl)(diphenoxyphosphoryl)methyl)carbamate $\quad(89)$. General procedure $\mathbf{C}$ with tert-butyl 5-chloro-3-formyl-1H-indole-1-carboxylate (500 mg, $1.78 \mathrm{mmol}$ ) to yield benzyl ((5-chloro-1H-indol-3-yl) (diphenoxyphosphoryl)methyl) carbamate (830 mg, $1.52 \mathrm{mmol}, 85 \%$ yield). ${ }^{1} \mathrm{H}$ NMR (400 MHz, DMSO- $\left.d_{6}\right) \delta: 11.43(\mathrm{~s}, 1 \mathrm{H}), 8.70(\mathrm{~d}, J=9.5 \mathrm{~Hz}, 1 \mathrm{H}), 7.77(\mathrm{~s}, 1 \mathrm{H}), 7.68$ (t, $J=2.5 \mathrm{~Hz}, 1 \mathrm{H}), 7.46-7.25(\mathrm{~m}, 10 \mathrm{H}), 7.24-7.05(\mathrm{~m}, 6 \mathrm{H}), 6.97(\mathrm{~d}, J=8.0 \mathrm{~Hz}, 2 \mathrm{H}), 5.82(\mathrm{dd}, J=21.0$ $10.0 \mathrm{~Hz}, 1 \mathrm{H}), 5.22-4.97(\mathrm{~m}, 2 \mathrm{H}) .{ }^{13} \mathrm{C}$ NMR $\left(100 \mathrm{MHz}, \mathrm{DMSO}-d_{6}\right) \delta: 156.1,150.3,150.0,136.8,134.4$, $129.8,128.4,127.9,127.4,127.0,127.0,125.2,123.9,121.57,120.4,118.4,113.3,107.5,66.1,45.3$ $\left(\mathrm{d}, J_{\mathrm{CP}}=165.5 \mathrm{~Hz}\right) . \mathrm{MS}(\mathrm{ESI}) \mathrm{m} / \mathrm{z} 547.1[\mathrm{M}+\mathrm{H}]^{+},(95 \%)$.

Benzyl ((6-carbamimidoylnaphthalen-2-yl)(diphenoxyphosphoryl)methyl)carbamate $(90) .{ }^{1} \mathrm{H}$ NMR (400 MHz, Methanol- $\left.d_{4}\right) \delta: 8.80-8.60(\mathrm{~m}, 1 \mathrm{H}), 8.46(\mathrm{~s}, 1 \mathrm{H}), 8.22(\mathrm{~s}, 1 \mathrm{H}), 8.15-8.08(\mathrm{~m}, 2 \mathrm{H})$, $8.00-7.65(\mathrm{~m}, 4 \mathrm{H}), 7.64-7.58(\mathrm{~m}, 1 \mathrm{H}), 7.45-7.12(\mathrm{~m}, 10 \mathrm{H}), 7.08-6.95(\mathrm{~m}, 5 \mathrm{H}), 6.00-5.78(\mathrm{~m}$, 1H), $5.25-5.11(\mathrm{~m}, 2 \mathrm{H})$. MS (ESI) $\mathrm{m} / z 566.2[\mathrm{M}+\mathrm{H}]^{+}$, (100\%). Procedure and characterization consistent with previously reported data. ${ }^{61}$

Benzyl ((diphenoxyphosphoryl)(4-nitrophenyl)methyl)carbamate (91). Procedure and characterization consistent with previously reported data. ${ }^{58}$

Benzyl ((3-carbamimidoylphenyl)(diphenoxyphosphoryl)methyl)carbamate (92). ${ }^{1} \mathrm{H} \quad \mathrm{NMR}$ $\left(400 \mathrm{MHz}, \mathrm{DMSO}-d_{6}\right) \delta: 9.63(\mathrm{~s}, 2 \mathrm{H}), 9.34(\mathrm{~s}, 2 \mathrm{H}), 8.96(\mathrm{~d}, J=10.0 \mathrm{~Hz}, 1 \mathrm{H}), 8.04(\mathrm{~d}, J=7.5 \mathrm{~Hz}, 2 \mathrm{H})$, $7.80(\mathrm{~d}, J=7.5 \mathrm{~Hz}, 1 \mathrm{H}), 7.67(\mathrm{t}, J=8.0 \mathrm{~Hz}, 1 \mathrm{H}), 7.43-7.28(\mathrm{~m}, 9 \mathrm{H}), 7.20(\mathrm{t}, J=7.0 \mathrm{~Hz}, 2 \mathrm{H}), 7.03$ $(\mathrm{dd}, J=18.0,8.0 \mathrm{~Hz}, 4 \mathrm{H}), 5.72(\mathrm{dd}, J=22.5,10.0 \mathrm{~Hz}, 1 \mathrm{H}), 5.11(\mathrm{dd}, J=39.0,12.5 \mathrm{~Hz}, 2 \mathrm{H}) .{ }^{13} \mathrm{C}$ NMR $\left(101 \mathrm{MHz}, \mathrm{DMSO}-d_{6}\right) \delta: 165.6,158.4,150.0,149.6,136.5,135.4133 .2,129.9,129.9,129.5,128.6$, $128.4,128.1,128.0,125.5,125.4,120.3,120.3,120.2,120.1,66.4,50.7\left(\mathrm{~d}, J_{\mathrm{CP}}=159.5 \mathrm{~Hz}\right) . \mathrm{MS}(\mathrm{ESI})$ $m / z$ 516.4 $[\mathrm{M}+\mathrm{H}]^{+},(100 \%)$. HRMS: Calc: 516.17 Found: $516.1703[\mathrm{M}+\mathrm{H}]^{+}$. Procedure and characterization consistent with previously reported data. ${ }^{50}$ 
Benzyl (1-(diphenoxyphosphoryl)-3-phenylpropyl)carbamate (93). ${ }^{1} \mathrm{H} \mathrm{NMR}\left(400 \mathrm{MHz}, \mathrm{CDCl}_{3}\right) \delta$ : $7.26(\mathrm{~s}, 20 \mathrm{H}), 5.26-5.07(\mathrm{~m}, 3 \mathrm{H}), 4.59-4.46(\mathrm{~m}, 1 \mathrm{H}), 2.92$ - $2.81(\mathrm{~m}, 1 \mathrm{H}), 2.80$ - $2.67(\mathrm{~m}, 1 \mathrm{H}), 2.44$ $2.29(\mathrm{~m}, 1 \mathrm{H}), 2.15-1.98(\mathrm{~m}, 1 \mathrm{H}) .{ }^{13} \mathrm{C} \mathrm{NMR}\left(100 \mathrm{MHz}, \mathrm{CDCl}_{3}\right) \delta: 156.0,150.3,150.1,140.6,136.1$, $130.0,129.9,128.7,128.7,128.6,128.5,128.3,126.4,125.5,120.7,120.5,67.6,48.3(\mathrm{~d}$, $\left.J_{\mathrm{CP}}=158.0 \mathrm{~Hz}\right), 32.1,32.0 . \mathrm{MS}(\mathrm{ESI}) \mathrm{m} / z 502.3[\mathrm{M}+\mathrm{H}]^{+}$. Synthetic procedures in the supporting information.

Benzyl ((diphenoxyphosphoryl)(naphthalen-1-yl)methyl)carbamate (94). ${ }^{1} \mathrm{H}$ NMR (400 MHz, $\left.\mathrm{CDCl}_{3}\right) \delta: 8.24(\mathrm{~d}, J=8.5 \mathrm{~Hz}, 1 \mathrm{H}), 7.81(\mathrm{dd}, J=14.0,8.0 \mathrm{~Hz}, 3 \mathrm{H}), 7.55-6.89(\mathrm{~m}, 14 \mathrm{H}), 6.60(\mathrm{~d}$, $J=8.0 \mathrm{~Hz}, 2 \mathrm{H}), 6.49-6.38(\mathrm{~m}, 1 \mathrm{H}), 6.04-5.88(\mathrm{~m}, 1 \mathrm{H}), 5.04(\mathrm{~m}, 2 \mathrm{H}) .{ }^{13} \mathrm{C} \mathrm{NMR}\left(100 \mathrm{MHz}, \mathrm{CDCl}_{3}\right)$ $\delta: 155.7,150.1,150.0,136.0,134.0,131.4,130.8,129.9,129.6,129.0,128.7,127.2,126.6,126.2$, 125.3, 123.3, 120.7, 120.2, 67.7, $48.4\left(\mathrm{~d}, J_{\mathrm{CP}}=161.0 \mathrm{~Hz}\right) . \mathrm{MS}(\mathrm{ESI}) \mathrm{m} / z 524.2[\mathrm{M}+\mathrm{H}]^{+}$. Synthetic procedures in the supporting information.

Benzyl ((diphenoxyphosphoryl)(naphthalen-2-yl)methyl)carbamate (95). ${ }^{1} \mathrm{H}$ NMR (400 MHz, $\left.\mathrm{CDCl}_{3}\right) \delta: 7.89-7.67(\mathrm{~m}, 4 \mathrm{H}), 7.56-6.93(\mathrm{~m}, 16 \mathrm{H}), 6.80(\mathrm{~m}, 2 \mathrm{H}), 5.96(\mathrm{~m}, 1 \mathrm{H}), 5.68(\mathrm{~m}, 1 \mathrm{H}), 5.02$ (m, 2H). $\left.{ }^{13} \mathrm{C} \mathrm{NMR} \mathrm{(100} \mathrm{MHz,} \mathrm{CDCl}_{3}\right) \delta: 156.0,150.2,136.0,133.3,131.7,129.9,129.8,128.9,128.7$, $128.5,128.3,127.8,126.7,125.6,125.5,120.6,120.5,67.8,53.1\left(\mathrm{~d}, J_{\mathrm{CP}}=157.0 \mathrm{~Hz}\right) . \mathrm{MS}(\mathrm{ESI}) \mathrm{m} / z$ $524.2[\mathrm{M}+\mathrm{H}]^{+}$. Synthetic procedures in the supporting information.

Benzyl ((3-cyanophenyl)(diphenoxyphosphoryl)methyl)carbamate (96). General procedure $\mathbf{C}$ with 3-cyanobenzaldehyde $\quad(447 \quad \mathrm{mg}, \quad 3.31 \quad \mathrm{mmol})$ to yield benzyl ((3cyanophenyl)(diphenoxyphosphoryl)methyl)carbamate (998 mg, $2.00 \mathrm{mmol}, 61 \%$ yield). ${ }^{1} \mathrm{H}$ NMR (400 MHz, DMSO- $\left.d_{6}\right) \delta:$ 7.81-6.89 (m, 19H), 6.15-6.04 (m, 1H), $5.14(\mathrm{dd}, J=23.0,10.5 \mathrm{~Hz}, 1 \mathrm{H}) . \mathrm{MS}$ (ESI) $m / z$ 499.5 [M+H] $]^{+}$. HRMS: Calc: 499.14 Found: $499.1431[\mathrm{M}+\mathrm{H}]^{+}$.

\section{Benzyl ((4-(dimethylamino)naphthalen-1-yl)(diphenoxyphosphoryl)methyl)carbamate (97).}

General procedure $\mathbf{C}$ with 4-dimethylamino-1-naphthaldehyde (200 mg, $1.004 \mathrm{mmol}$ ) to yield benzyl ((4-(dimethylamino)naphthalen-1-yl)(diphenoxyphosphoryl)methyl) carbamate $(21 \mathrm{mg}, 0.04 \mathrm{mmol}$, $4 \%$ yield). ${ }^{1} \mathrm{H}$ NMR $\left(400 \mathrm{MHz}, \mathrm{CDCl}_{3}\right) \delta: 8.18(\mathrm{t}, J=8.0 \mathrm{~Hz}, 1 \mathrm{H}), 7.69(\mathrm{dd}, J=8.0,2.5 \mathrm{~Hz}, 1 \mathrm{H}), 7.51$ - $7.38(\mathrm{~m}, 1 \mathrm{H}), 7.28-6.85(\mathrm{~m}, 7 \mathrm{H}), 6.56(\mathrm{~d}, \mathrm{~J}=8.1 \mathrm{~Hz}, 1 \mathrm{H}), 6.34(\mathrm{dd}, \mathrm{J}=22.5,9.9 \mathrm{~Hz}, 1 \mathrm{H}), 5.98-5.93$ $(\mathrm{m}, 1 \mathrm{H}), 5.00(\mathrm{dt}, J=28.0,12.0 \mathrm{~Hz}, 1 \mathrm{H}), 2.78(\mathrm{~s}, 3 \mathrm{H}), 1.18-1.13(\mathrm{~m}, 1 \mathrm{H}) \cdot{ }^{13} \mathrm{C} \mathrm{NMR}\left(100 \mathrm{MHz}, \mathrm{CDCl}_{3}\right)$ 
$1 \delta: 155.7,152.0,150.6,150.2,136.1,132.6,129.8,129.1,129.1,128.6,128.3,126.9,125.4,125.1$,

$2 \quad 124.8,123.6,120.7,120.2,113.5,67.0,48.2\left(\mathrm{~d}, J_{\mathrm{CP}}=162.0 \mathrm{~Hz}\right), 44.9 . \mathrm{MS}(\mathrm{ESI}) \mathrm{m} / z 567.2[\mathrm{M}+\mathrm{H}]^{+}$.

3

4

5

6

7

8

9

10

Benzyl ((diphenoxyphosphoryl)(4-(2,2,2-trifluoroacetamido)phenyl)methyl)carbamate (98).

General procedure $\mathbf{C}$ with 2,2,2-trifluoro- $N$-(4-formylphenyl)acetamide (70 $\mathrm{mg}, 0.32 \mathrm{mmol}$ ) to yield benzyl ((diphenoxyphosphoryl)(4-(2,2,2-trifluoroacetamido)phenyl)methyl)carbamate $\quad(17 \quad \mathrm{mg}$, 0.03 mmol, $9 \%$ yield). ${ }^{1} \mathrm{H}$ NMR (400 MHz, $\left.\mathrm{CDCl}_{3}\right) \delta: 8.00(\mathrm{~s}, 1 \mathrm{H}), 7.55,7.50-7.00$ (m, $\left.14 \mathrm{H}\right), 5.75$ (m, 1H), $5.50(\mathrm{~m}, 1 \mathrm{H}), 5.10(\mathrm{~m}, 2 \mathrm{H}) . \mathrm{MS}(\mathrm{ESI}) \mathrm{m} / \mathrm{z} 585.2[\mathrm{M}+\mathrm{H}]^{+}$.

Tert-butyl 4-(4-((((benzyloxy)carbonyl)amino)(diphenoxyphosphoryl) methyl)phenyl)piperazine1-carboxylate (99). General procedure $\mathbf{C}$ with tert-butyl 4-(4-formylphenyl)piperazine-1-carboxylate (200 $\mathrm{mg}, \quad 0.69 \mathrm{mmol})$ to yield 4-(4-((benzyloxycarbonylamino)(diphenoxyphosphoryl) methyl)phenyl)piperazine-1-carboxylate ( $80 \mathrm{mg}, 0.12 \mathrm{mmol}, 17 \%$ yield). ${ }^{1} \mathrm{H}$ NMR (400 MHz, $\left.\mathrm{CDCl}_{3}\right)$

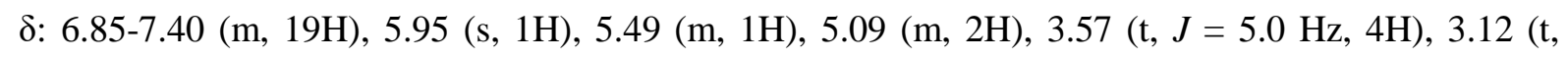
$J=5.0 \mathrm{~Hz}, 4 \mathrm{H}), 1.48(\mathrm{~s}, 9 \mathrm{H}) . \mathrm{MS}(\mathrm{ESI}) \mathrm{m} / z, 680.2[\mathrm{M}+\mathrm{Na}]^{+}$.

\section{Tert-butyl}

4-(4-((((benzyloxy)carbonyl)amino)(diphenoxyphosphoryl)methyl)-2cyanophenyl)piperazine-1-carboxylate (100). General procedure $\mathbf{C}$ with tert-butyl 4-(2-cyano-4formylphenyl)piperazine-1-carboxylate $\quad(500 \mathrm{mg}, \quad 1.59 \mathrm{mmol}), \quad$ to $\quad$ yield tert-butyl 4-(4((((benzyloxy)carbonyl)amino)(diphenoxyphosphoryl)methyl)-2-cyanophenyl)piperazine-1carboxylate (457 mg, $0.67 \mathrm{mmol}, 42 \%$ yield). MS (ESI) $\mathrm{m} / z, 705.3[\mathrm{M}+\mathrm{Na}]^{+}$.

Tert-butyl 4-((benzyloxycarbonylamino)(diphenoxyphosphoryl)methyl)piperidine-1-carboxylate (101). General procedure $\mathbf{C}$ with tert-butyl 4-formylpiperidine-1-carboxylate (120 $\mathrm{mg}, 0.56 \mathrm{mmol})$ to yield tert-butyl 4-((benzyloxycarbonylamino)(diphenoxyphosphoryl)methyl)piperidine-1-carboxylate (100 mg, $0.17 \mathrm{mmol}, 30 \%$ yield). MS (ESI) $\mathrm{m} / \mathrm{z} 603.1[\mathrm{M}+\mathrm{Na}]^{+}$.

\section{Tert-butyl}

4-(2-(benzyloxycarbonylamino)-2-(diphenoxyphosphoryl)ethyl)piperidine-1carboxylate (102). General procedure $\mathbf{C}$ with tert-butyl 4-(2-oxoethyl)piperidine-1-carboxylate (600 mg, $\quad 2.64 \mathrm{mmol}) \quad$ to give tert-butyl 4-(2-(benzyloxycarbonylamino)-2(diphenoxyphosphoryl)ethyl)piperidine-1-carboxylate (250 mg, $0.42 \mathrm{mmol}, 16 \%$ yield). MS (ESI) $\mathrm{m} / \mathrm{z}$ $595.9[\mathrm{M}+\mathrm{H}]^{+}$. 

$0.42 \mathrm{mmol}, 25 \%$ yield). MS (ESI) $\mathrm{m} / \mathrm{z} 609.6[\mathrm{M}+\mathrm{H}]^{+}$.

Tert-butyl

3-((((benzyloxy)carbonyl)amino)(diphenoxyphosphoryl)methyl)azetidine-1carboxylate (104). General procedure $\mathbf{C}$ with tert-butyl 3-formylazetidine-1-carboxylate $(613 \mathrm{mg}$, $3.31 \mathrm{mmol}) \quad$ to $\quad$ yield tert-butyl $3-(((($ benzyloxy)carbonyl)amino)(diphenoxyphosphoryl) methyl)azetidine-1-carboxylate as a white solid (1.084 g, $1.96 \mathrm{mmol}, 59 \%$ yield). ${ }^{1} \mathrm{H}$ NMR (400 MHz, DMSO- $\left.d_{6}\right) \delta: 6.38(\mathrm{dd}, J=23.5,10.5 \mathrm{~Hz}, 1 \mathrm{H}), 6.74(\mathrm{t}, J=5.0 \mathrm{~Hz}, 1 \mathrm{H}), 7.02(\mathrm{ddq}, J=16.0,8.0,1.0 \mathrm{~Hz}$ 4H), $7.15-7.24(\mathrm{~m}, 2 \mathrm{H}), 7.28-7.40(\mathrm{~m}, 4 \mathrm{H}), 7.63(\mathrm{t}, J=8.0 \mathrm{~Hz}, 1 \mathrm{H}), 7.83(\mathrm{dq}, J=8.0,1.5 \mathrm{~Hz}, 1 \mathrm{H})$, $8.04-8.15(\mathrm{~m}, 1 \mathrm{H}), 8.27(\mathrm{q}, J=2.0 \mathrm{~Hz}, 1 \mathrm{H}), 8.38(\mathrm{~d}, J=5.0 \mathrm{~Hz}, 2 \mathrm{H}), 8.65(\mathrm{dd}, J=10.5,2.5 \mathrm{~Hz}, 1 \mathrm{H})$.

Benzyl (2-(4-((tert-butoxycarbonyl)amino)phenyl)-1-(diphenoxyphosphoryl)ethyl)carbamate (105). Procedure and characterization consistent with previously reported data. ${ }^{53}$

\section{Benzyl}

((6-((tert-butoxycarbonyl)amino)naphthalen-2yl)(diphenoxyphosphoryl)methyl)carbamate (106). General procedure C with tert-butyl 6formylnaphthalen-2-ylcarbamate $\quad(300 \mathrm{mg}, \quad 1,106 \mathrm{mmol}) \quad$ to yield benzyl $((6-(($ tertbutoxycarbonyl)amino)naphthalen-2-yl)(diphenoxyphosphoryl)methyl)carbamate $\quad(350 \quad \mathrm{mg}$, $0.55 \mathrm{mmol}, 50 \%$ yield). ${ }^{1} \mathrm{H} \mathrm{NMR}\left(400 \mathrm{MHz}, \mathrm{CDCl}_{3}\right) \delta: 9.57(\mathrm{~s}, 1 \mathrm{H}), 8.94(\mathrm{~d}, J=10.0 \mathrm{~Hz}, 1 \mathrm{H}), 8.07$ (br s, 1H), $7.98($ br s, 1H), $7.65(\mathrm{~d}, J=8.5 \mathrm{~Hz}, 1 \mathrm{H}), 7.28(\mathrm{~m}, 9 \mathrm{H}), 7.47(\mathrm{dd}, J=2.0,8.5 \mathrm{~Hz}, 1 \mathrm{H}), 7.14(\mathrm{t}$, $J=6.0 \mathrm{~Hz}, 2 \mathrm{H}), 7.01(\mathrm{~d}, J=8.5 \mathrm{~Hz}, 2 \mathrm{H}), 6.92(\mathrm{~d}, J=8.5 \mathrm{~Hz}, 2 \mathrm{H}), 5.65(\mathrm{~m}, 1 \mathrm{H}), 5.09(\mathrm{~d}, J=12.5 \mathrm{~Hz}$, 1H), $5.01(\mathrm{~d}, J=12.5 \mathrm{~Hz}, 1 \mathrm{H}), 1.47(\mathrm{~s}, 9 \mathrm{H}) . \mathrm{MS}(\mathrm{ESI}) \mathrm{m} / \mathrm{z} 639.1[\mathrm{M}+\mathrm{H}]^{+}$

Benzyl ((diphenoxyphosphoryl)(4-(piperazin-1-yl)phenyl)methyl)carbamate 2,2,2trifluoroacetate (107). General procedure $\mathbf{H}$ with tert-butyl 4-(4((benzyloxycarbonylamino)(diphenoxyphosphoryl)methyl)phenyl)piperazine-1-carboxylate $(800 \mathrm{mg}, \quad 1.22 \mathrm{mmol}) \quad$ to afford benzyl (diphenoxyphosphoryl)(4-(piperazin-1yl)phenyl)methylcarbamate 2,2,2-trifluoroacetate (75 mg, $0.11 \mathrm{mmol}, 9 \%$ yield). ${ }^{1} \mathrm{H} \mathrm{NMR}(400 \mathrm{MHz}$, 
Methanol- $\left.d_{4}\right) \delta: 6.90-7.50(\mathrm{~m}, 19 \mathrm{H}), 5.53(\mathrm{~d}, J=20.0 \mathrm{~Hz}, 1 \mathrm{H}), 5.12(\mathrm{~m}, 2 \mathrm{H}), 3.48(\mathrm{~m}, 4 \mathrm{H}), 3.37(\mathrm{~m}$, 4H). ${ }^{13} \mathrm{C}$ NMR (100 MHz, Methanol- $\left.d_{4}\right) \delta: 158.3,158.2,151.7,151.4,138.0,130.8,130.7,129.5,129.1$, $129.0,126.6,121.8,121.7,121.6,121.5,117.9,117.8,68.2,53.7\left(\mathrm{~d}, J_{\mathrm{CP}}=159.5 \mathrm{~Hz}\right), 47.5,44.7 . \mathrm{MS}$ (ESI) $m / z 558.2[\mathrm{M}+\mathrm{H}]^{+},(95 \%)$. HRMS: Calc: 558.22 Found: $558.2163[\mathrm{M}+\mathrm{H}]^{+}$.

\section{Benzyl ((3-cyano-4-(piperazin-1-yl)phenyl)(diphenoxyphosphoryl)methyl)carbamate 2,2,2-} trifluoroacetate (108). General procedure $\mathbf{H}$ with tert-butyl 4-(4((((benzyloxy)carbonyl)amino)(diphenoxyphosphoryl)methyl)-2-cyanophenyl)piperazine-1carboxylate (100) (120 mg, $0.18 \mathrm{mmol})$ to yield benzyl ((3-cyano-4-(piperazin-1yl)phenyl)(diphenoxyphosphoryl)methyl)carbamate 2,2,2-trifluoroacetate (9 $\mathrm{mg}, 0.15 \mathrm{mmol}, 9 \%)$ as a colourless oil. ${ }^{1} \mathrm{H}$ NMR (400 MHz, CDCl3) $\delta: 7.59(\mathrm{dd}, J=28.5,19.5 \mathrm{~Hz}, 2 \mathrm{H}), 7.44-7.27(\mathrm{~m}, 6 \mathrm{H})$, $7.24-6.74(\mathrm{~m}, 11 \mathrm{H}), 5.99(\mathrm{~s}, 1 \mathrm{H}), 5.48(\mathrm{dd}, J=22.5,9.5 \mathrm{~Hz}, 1 \mathrm{H}), 5.24-4.95(\mathrm{~m}, 2 \mathrm{H}), 3.31-3.11(\mathrm{~m}$, 4H), $3.06(\mathrm{~s}, 4 \mathrm{H}) .{ }^{13} \mathrm{C}$ NMR (100 MHz, CDCl3) $\delta: 156.0,155.1,150.0,135.6,133.9,133.9,130.0$, $129.7,128.8,128.6,128.4,127.7,125.7,120.5,120.4,120.4,120.3,119.2,117.9,115.5,105.7,67.9$, 52.6, $51.0\left(\mathrm{~d}, J_{\mathrm{CP}}=151.5 \mathrm{~Hz}\right), 45.61 . \mathrm{MS}(\mathrm{ESI}) \mathrm{m} / z$. $583.2[\mathrm{M}+\mathrm{H}]^{+}$.

Benzyl ((diphenoxyphosphoryl)(piperidin-4-yl)methyl)carbamate 2,2,2-trifluoroacetate (109). General procedure H with tert-butyl $4-$ ((((benzyloxy)carbonyl)amino)(diphenoxyphosphoryl)methyl)piperidine-1-carboxylate (101) (900 mg, $1.55 \mathrm{mmol}$ ) to give benzyl ((diphenoxyphosphoryl)(piperidin-4-yl)methyl)carbamate 2,2,2trifluoroacetate $\left(520 \mathrm{mg}, 0.87 \mathrm{mmol}, 56 \%\right.$ yield). ${ }^{1} \mathrm{H}$ NMR $\left(400 \mathrm{MHz}\right.$, Methanol- $\left.d_{4}\right) \delta: 8.05$ (d, $J=10.5 \mathrm{~Hz}, 1 \mathrm{H}), 7.34(\mathrm{~m}, 9 \mathrm{H}), 7.23(\mathrm{~m}, 2 \mathrm{H}), 7.14(\mathrm{~m}, 4 \mathrm{H}), 5.14(\mathrm{~m}, 2 \mathrm{H}), 4.46(\mathrm{~m}, 1 \mathrm{H}), 3.45(\mathrm{~m}, 2 \mathrm{H})$, $2.40(\mathrm{~m}, 1 \mathrm{H}), 2.31(\mathrm{~m}, 2 \mathrm{H}), 2.21(\mathrm{~m}, 2 \mathrm{H}), 1.71(\mathrm{~m}, 2 \mathrm{H}) . \mathrm{MS}(\mathrm{ESI}) \mathrm{m} / z 481.7[\mathrm{M}+\mathrm{H}]^{+}$.

Benzyl 1-(diphenoxyphosphoryl)-2-(piperidin-4-yl)ethylcarbamate 2,2,2-trifluoroacetate (110). General Procedure $\mathrm{H}$ with tert-butyl 4-(2-(benzyloxycarbonylamino)-2(diphenoxyphosphoryl)ethyl)piperidine-1-carboxylate (102) $(250 \mathrm{mg}, 0.42 \mathrm{mmol})$ to give benzyl 1(diphenoxyphosphoryl)-2-(piperidin-4-yl)ethylcarbamate 2,2,2-trifluoroacetate (200 mg, $0.33 \mathrm{mmol}$, $78 \%$ yield). ${ }^{1} \mathrm{H}$ NMR (400 MHz, Methanol- $\left.d_{4}\right) \delta: 7.36(\mathrm{~m}, 9 \mathrm{H}), 7.22(\mathrm{~m}, 2 \mathrm{H}), 7.14(\mathrm{~m}, 4 \mathrm{H}), 5.14(\mathrm{q}$, $J=12.5 \mathrm{~Hz}, 2 \mathrm{H}), 4.53(\mathrm{~m}, 1 \mathrm{H}), 3.60(\mathrm{~d}, J=12.5 \mathrm{~Hz}, 2 \mathrm{H}), 2.95(\mathrm{dt}, J=12.5,2.5 \mathrm{~Hz}, 1 \mathrm{H}), 2.85(\mathrm{dt}$, 
$J=12.5,2.5 \mathrm{~Hz}, 1 \mathrm{H}), 2.05(\mathrm{~m}, 1 \mathrm{H}), 1.90(\mathrm{~m}, 3 \mathrm{H}), 1.81(\mathrm{~m}, 1 \mathrm{H}), 1.52(\mathrm{~m}, 1 \mathrm{H}), 1.35(\mathrm{~m}, 1 \mathrm{H}) . \mathrm{MS}(\mathrm{ESI})$ $m / z 495.2[\mathrm{M}+\mathrm{H}]^{+}$

Benzyl ((4-(aminomethyl)cyclohexyl)(diphenoxyphosphoryl)methyl)carbamate trifluoroacetate (111). General procedure $\mathbf{H}$ with benzyl ((4-(((tertbutoxycarbonyl)amino)methyl)cyclohexyl)(diphenoxyphosphoryl)methyl)carbamate (103) (252 mg, $0.42 \mathrm{mmol})$ to yield benzyl ((4-(aminomethyl)cyclohexyl)(diphenoxyphosphoryl)methyl)carbamate 2,2,2-trifluoroacetate (180 mg, $0.35 \mathrm{mmol}, 83 \%$ yield) as a colourless oil. ${ }^{1} \mathrm{H}$ NMR $(400 \mathrm{MHz}$, Methanol- $\left.d_{4}\right) \delta: 7.32(\mathrm{~m}, 9 \mathrm{H}), 7.21(\mathrm{~m}, 2 \mathrm{H}), 7.11(\mathrm{~m}, 3 \mathrm{H}), 5.18(\mathrm{~d}, J=12.5 \mathrm{~Hz}, 1 \mathrm{~h}), 5.10(\mathrm{~d}, J=12.5 \mathrm{~Hz}$, 1H), $4.37(\mathrm{~m}, 1 \mathrm{H}), 2.79(\mathrm{~d}, J=7.0 \mathrm{~Hz}, 2 \mathrm{H}), 2.10(\mathrm{~m}, 3 \mathrm{H}), 1.90(\mathrm{~m}, 2 \mathrm{H}), 1.60(\mathrm{~m}, 2 \mathrm{H}), 1.30(\mathrm{~m}, 2 \mathrm{H})$, $1.11(\mathrm{~m}, 2 \mathrm{H}) . \mathrm{MS}(\mathrm{ESI}) \mathrm{m} / \mathrm{z} 509.1[\mathrm{M}+\mathrm{H}]^{+}$.

Benzyl (azetidin-3-yl(diphenoxyphosphoryl)methyl)carbamate 2,2,2-trifluoroacetate (112). General procedure $\mathbf{H}$ with tert-butyl 3-(((benzyloxy)carbonyl)amino)(diphenoxyphosphoryl) methyl)azetidine-1-carboxylate (104) (1.084 g, $1.96 \mathrm{mmol})$ to yield benzyl (azetidin-3yl(diphenoxyphosphoryl)methyl)carbamate 2,2,2-trifluoroacetate ( $884 \mathrm{mg}, 1.61 \mathrm{mmol}, 82 \%$ yield). MS (ESI) $m / z 453.4[\mathrm{M}+\mathrm{H}]^{+}$.

\section{Benzyl (2-(4-aminophenyl)-1-(diphenoxyphosphoryl)ethyl)carbamate 2,2,2-trifluoroacetate}

(113). Procedure and characterization consistent with previously reported data. ${ }^{53}$

\section{Benzyl ((6-aminonaphthalen-2-yl)(diphenoxyphosphoryl)methyl)carbamate (114)}

General procedure $\mathbf{H}$ with benzyl ((6-((tert-butoxycarbonyl)amino)naphthalen-2yl)(diphenoxyphosphoryl)methyl)carbamate (106) (350 $\mathrm{mg}, 0.55 \mathrm{mmol})$ to yield benzyl (6aminonaphthalen-2-yl)(diphenoxyphosphoryl)methylcarbamate $\quad$ 2,2,2-trifluoroacetate $\quad(210 \quad \mathrm{mg}$, $0.32 \mathrm{mmol}, 59 \%$ yield) as a colourless oil. ${ }^{1} \mathrm{H}$ NMR $\left(400 \mathrm{MHz}\right.$, Methanol- $\left.d_{4}\right) \delta: 9.76(\mathrm{~d}, J=10.0 \mathrm{~Hz}$, $1 \mathrm{H}), 8.77(\mathrm{~s}, 1 \mathrm{H}), 8.50(\mathrm{~m}, 3 \mathrm{H}), 8.15(\mathrm{~m}, 9 \mathrm{H}), 8.01(\mathrm{~m}, 2 \mathrm{H}), 7.89(\mathrm{~m}, 3 \mathrm{H}), 7.80(\mathrm{~d}, J=8.0 \mathrm{~Hz}, 2 \mathrm{H})$, $6.49(\mathrm{~m}, 1 \mathrm{H}), 5.96(\mathrm{~d}, J=12.5 \mathrm{~Hz}, 1 \mathrm{H}), 5.87(\mathrm{~d}, J=12.5 \mathrm{~Hz}, 1 \mathrm{H}) . \mathrm{MS}(\mathrm{ESI}) \mathrm{m} / z 539.9[\mathrm{M}+\mathrm{H}]^{+}$.

\section{Benzyl ((1-carbamimidoylazetidin-3-yl)(diphenoxyphosphoryl)methyl)carbamate} trifluoroacetate (115). General procedure I followed by general procedure $\mathbf{H}$ with benzyl (azetidin-3yl(diphenoxyphosphoryl)methyl)carbamate 2,2,2-trifluoroacetate (112) (884 mg, $1.61 \mathrm{mmol})$ to yield benzyl ((1-carbamimidoylazetidin-3-yl)(diphenoxyphosphoryl)methyl) carbamate 
1 trifluoroacetate (357 mg, $0.72 \mathrm{mmol}, 45 \%$ yield). ${ }^{1} \mathrm{H}$ NMR (400 MHz, DMSO- $\left.d_{6}\right) \delta: 8.35$ (dd, $J=15.0$, $10.0 \mathrm{~Hz}, 1 \mathrm{H}), 7.47-7.27(\mathrm{~m}, 9 \mathrm{H}), 7.23(\mathrm{dt}, J=11.5,6.0 \mathrm{~Hz}, 2 \mathrm{H}), 7.15(\mathrm{dd}, J=8.5,7.0 \mathrm{~Hz}, 4 \mathrm{H}), 5.21$ $-4.97(\mathrm{~m}, 2 \mathrm{H}), 4.86-4.68(\mathrm{~m}, 1 \mathrm{H}), 4.28-4.09(\mathrm{~m}, 2 \mathrm{H}), 4.03(\mathrm{dt}, J=17.5,7.0 \mathrm{~Hz}, 2 \mathrm{H}), 3.42-3.27$ (m, 1H). ${ }^{13} \mathrm{C}$ NMR (100 MHz, DMSO-d $) \delta: 156.3,151.7,149.6,136.6,130.0,128.5,128.0,127.8$, $125.5,125.4,120.6,120.4,66.2,52.8,49.7\left(\mathrm{~d}, J_{\mathrm{CP}}=157.5 \mathrm{~Hz}\right), 28.0 . \mathrm{MS}(\mathrm{ESI}) \mathrm{m} / \mathrm{z} 495.4[\mathrm{M}+\mathrm{H}]^{+}$, (100\%). HRMS: Calc: 495.18 Found: $495.1785[\mathrm{M}+\mathrm{H}]^{+}$.

Benzyl 2-(4-acetamidophenyl)-1-(diphenoxyphosphoryl)ethylcarbamate (116). General procedure J with acetyl chloride (27 $\mu \mathrm{L}, 0.38 \mathrm{mmol}, 1.2$ eq) and benzyl 2-(4-aminophenyl)-1(diphenoxyphosphoryl)ethylcarbamate $\quad(\mathbf{1 1 3}) \quad(160 \mathrm{mg}, \quad 0.32 \mathrm{mmol})$ to yield benzyl 2-(4acetamidophenyl)-1-(diphenoxyphosphoryl)ethylcarbamate (104 mg, $0.19 \mathrm{mmol}, 60 \%$ yield). ${ }^{1} \mathrm{H}$ NMR (400 MHz, Methanol- $\left.d_{4}\right) \delta: 7.55-7.45(\mathrm{~m}, 2 \mathrm{H}), 7.40-7.30(\mathrm{~m}, 4 \mathrm{H}), 7.30-7.17$ (m, 9H), 7.15 (dd, $J$ $=5.5,4.5 \mathrm{~Hz}, 4 \mathrm{H}), 5.06-4.93(\mathrm{~m}, 2 \mathrm{H}), 4.63(\mathrm{qd}, J=11.5,5.5 \mathrm{~Hz}, 1 \mathrm{H}), 3.39-3.32(\mathrm{~m}, 1 \mathrm{H}), 3.01(\mathrm{ddd}$, $J=14.0,12.0,9.0 \mathrm{~Hz}, 1 \mathrm{H}), 2.12(\mathrm{~s}, 3 \mathrm{H}) .{ }^{13} \mathrm{C} \mathrm{NMR}\left(100 \mathrm{MHz}\right.$, Methanol- $\left.d_{4}\right) \delta: 171.6,159.0,151.8$, $151.4,138.9,138.1,133.6,131.00,130.9,130.7,129.4,128.9,128.6,126.8,126.7,121.8,121.8,121.7$, 121.6, 121.1, 67.7, $51.4\left(\mathrm{~d}, J_{\mathrm{CP}}=158.5 \mathrm{~Hz}\right), 35.6,23.8 . \mathrm{MS}(\mathrm{ESI}) \mathrm{m} / z 545.7[\mathrm{M}+\mathrm{H}]^{+}$

Benzyl ((diphenoxyphosphoryl)(5-nitronaphthalen-1-yl)methyl)carbamate (117). General procedure $\mathbf{C}$ with 5-nitro-1-naphthaldehyde $(200 \mathrm{mg}, 0.99 \mathrm{mmol})$, to give benzyl ((diphenoxyphosphoryl)(5-nitronaphthalen-1-yl)methyl)carbamate (568 mg, $0.35 \mathrm{mmol}, 35 \%$ yield). ${ }^{1} \mathrm{H}$ NMR $\left(400 \mathrm{MHz}, \mathrm{CDCl}_{3}\right) \delta: 8.62(\mathrm{~d}, J=9.0 \mathrm{~Hz}, 1 \mathrm{H}), 8.48(\mathrm{~d}, J=9.0 \mathrm{~Hz}, 1 \mathrm{H}), 8.20(\mathrm{~d}, J=8.0 \mathrm{~Hz}$, 1H), $7.99(\mathrm{~s}, 1 \mathrm{H}), 7.76-7.62(\mathrm{~m}, 2 \mathrm{H}), 7.42-7.28(\mathrm{~m}, 8 \mathrm{H}), 7.13(\mathrm{~m}, 7 \mathrm{H}), 6.73(\mathrm{~d}, J=8.5 \mathrm{~Hz}, 2 \mathrm{H}), 6.44$ $(\mathrm{d}, J=23.5 \mathrm{~Hz}, 1 \mathrm{H}), 6.03(\mathrm{~s}, 1 \mathrm{H}), 5.12(\mathrm{dd}, J=43.5,12.0 \mathrm{~Hz}, 2 \mathrm{H}) . \mathrm{MS}(\mathrm{ESI}) \mathrm{m} / z .569 .3[\mathrm{M}+\mathrm{H}]^{+}$.

Benzyl ((4-(dimethylamino)-3-nitrophenyl)(diphenoxyphosphoryl)methyl)carbamate (118). General procedure $\mathbf{C}$ with 5-nitro-1-naphthaldehyde with 4-(dimethylamino)-3-nitrobenzaldehyde (500 $\mathrm{mg}, \quad 2.57 \quad \mathrm{mmol}), \quad$ to $\quad$ yield benzyl ((4-(dimethylamino)-3nitrophenyl)(diphenoxyphosphoryl)methyl)carbamate (793 mg, $1.41 \mathrm{mmol}, 55 \%$ yield). ${ }^{1} \mathrm{H}$ NMR $\left(400 \mathrm{MHz}, \mathrm{CDCl}_{3}\right) \delta: 7.91(\mathrm{~s}, 1 \mathrm{H}), 7.54(\mathrm{~d}, J=8.5 \mathrm{~Hz}, 1 \mathrm{H}), 7.35(\mathrm{~s}, 5 \mathrm{H}), 7.30-7.20(\mathrm{~m}, 5 \mathrm{H}), 7.20$ $7.05(\mathrm{~m}, 4 \mathrm{H}), 7.00(\mathrm{t}, J=9.0 \mathrm{~Hz}, 3 \mathrm{H}), 6.00(\mathrm{dd}, J=9.0,4.5 \mathrm{~Hz}, 1 \mathrm{H}), 5.51(\mathrm{dd}, J=22.5,9.5 \mathrm{~Hz}, 1 \mathrm{H})$, 5.21 - $4.99(\mathrm{~m}, 2 \mathrm{H}), 2.91(\mathrm{~s}, 6 \mathrm{H}) .{ }^{13} \mathrm{C}$ NMR (100 MHz, CDCl3) $\delta: 155.7,150.0,145.9,138.4,135.8$, 
$133.4,129.8,128.6,128.4,128.3,126.5,125.6,123.8,120.4,120.3,118.7,67.7,51.5$ (d, $\left.J_{\mathrm{CP}}=159.0 \mathrm{~Hz}\right), 42.5 . \mathrm{MS}(\mathrm{ESI}) \mathrm{m} / z 562.2[\mathrm{M}+\mathrm{H}]^{+}$.

Benzyl ((5-aminonaphthalen-1-yl)(diphenoxyphosphoryl)methyl)carbamate (119). General procedure K with benzyl ((diphenoxyphosphoryl)(5-nitronaphthalen-1-yl)methyl)carbamate (117) (500 $\mathrm{mg}, 0.88 \mathrm{mmol})$ to give benzyl ((5-aminonaphthalen-1-yl)(diphenoxyphosphoryl)methyl)carbamate (440 mg, $0.82 \mathrm{mmol}, 93 \%$ yield). MS (ESI) $\mathrm{m} / z 539.3[\mathrm{M}+\mathrm{Na}]^{+}$

Benzyl (3-(4-aminophenyl)-1-(diphenoxyphosphoryl)propyl)carbamate (120). General procedure K with benzyl (1-(diphenoxyphosphoryl)-3-(4-nitrophenyl)propyl)carbamate (70) (8.03 g, 14.69 mmol) to yield benzyl (3-(4-aminophenyl)-1-(diphenoxyphosphoryl)propyl)carbamate (4.24 g, 8.21 mmol, 56\% yield). ${ }^{1} \mathrm{H}$ NMR (400 MHz, DMSO- $\left.d_{6}\right) \delta: 8.12(\mathrm{~d}, J=9.5 \mathrm{~Hz}, 1 \mathrm{H}), 7.40-7.27(\mathrm{~m}, 9 \mathrm{H})$, $7.20(\mathrm{q}, J=7.0 \mathrm{~Hz}, 2 \mathrm{H}), 7.08(\mathrm{dd}, J=12.0,8.5 \mathrm{~Hz}, 4 \mathrm{H}), 6.84(\mathrm{~d}, J=8.5 \mathrm{~Hz}, 2 \mathrm{H}), 6.51(\mathrm{~d}, J=8.5 \mathrm{~Hz}$, 2H), 5.15 - $5.07(\mathrm{~m}, 2 \mathrm{H}), 5.07$ - $4.95(\mathrm{~m}, 2 \mathrm{H}), 4.33$ - $4.13(\mathrm{~m}, 1 \mathrm{H}), 2.72$ - $2.58(\mathrm{~m}, 1 \mathrm{H}), 2.49$ - $2.37(\mathrm{~m}$, 1H), 2.13 - $1.96(\mathrm{~m}, 2 \mathrm{H}) .{ }^{13} \mathrm{C}$ NMR (100 MHz, DMSO- $\left.d_{6}\right) \delta: 156.1,150.0,149.8,146.5,137.0,130.3$, $129.8,129.0,128.4,127.9,127.8,127.5,125.2,120.6,120.4,114.2,65.8,47.5\left(\mathrm{~d}, J_{\mathrm{CP}}=158.0 \mathrm{~Hz}\right)$, 30.9, 30.3. MS (ESI) m/z 517.2 [M+H] $]^{+}$. HRMS: Calc: 517.19 Found: $517.1871[\mathrm{M}+\mathrm{H}]^{+}$.

Benzyl ((3-amino-4-(dimethylamino)phenyl)(diphenoxyphosphoryl)methyl)carbamate (121). General procedure $\quad \mathbf{K}$ with benzyl ((4-(dimethylamino)-3nitrophenyl)(diphenoxyphosphoryl)methyl)carbamate (118) (793 mg, $1.41 \mathrm{mmol})$ to give benzyl ((3amino-4-(dimethylamino)phenyl)(diphenoxyphosphoryl)methyl)carbamate (310 mg, $0.58 \mathrm{mmol}, 41 \%$ yield).${ }^{1} \mathrm{H}$ NMR $\left(400 \mathrm{MHz}, \mathrm{CDCl}_{3}\right) \delta: 7.40-7.28(\mathrm{~m}, 4 \mathrm{H}), 7.25-7.04(\mathrm{~m}, 9 \mathrm{H}), 6.95(\mathrm{~d}, J=8.0 \mathrm{~Hz}$, $1 \mathrm{H}), 6.84(\mathrm{~d}, J=8.5 \mathrm{~Hz}, 4 \mathrm{H}), 5.88(\mathrm{dd}, J=10.0,3.0 \mathrm{~Hz}, 1 \mathrm{H}), 5.45(\mathrm{dd}, J=22.0,10.0 \mathrm{~Hz}, 1 \mathrm{H}), 5.09$ $(\mathrm{dd}, J=40.0,12.0 \mathrm{~Hz}, 2 \mathrm{H}), 4.42-3.52(\mathrm{~m}, 2 \mathrm{H}), 2.67(\mathrm{~s}, 6 \mathrm{H}) .{ }^{13} \mathrm{C} \mathrm{NMR}\left(100 \mathrm{MHz}, \mathrm{CDCl}_{3}\right) \delta:$ 155.6, $150.2,141.6,136.0,129.9,129.7,129.6,128.6,128.3,125.4,125.3,120.6,120.5,120.1,119.6,118.4$, 115.0, 67.5, $52.6\left(\mathrm{~d}, J_{\mathrm{CP}}=159.0 \mathrm{~Hz}\right), 43.6 . \mathrm{MS}(\mathrm{ESI}) \mathrm{m} / z 532.2[\mathrm{M}+\mathrm{H}]^{+}$.

Benzyl ((4-acetamidophenyl)(diphenoxyphosphoryl)methyl)carbamate (122). General procedure J with acetyl chloride $(28 \mu \mathrm{L}, \quad 0.39 \quad \mathrm{mmol}, \quad 1.2 \quad$ eq) and benzyl (4aminophenyl)(diphenoxyphosphoryl)methylcarbamate $(\mathbf{5 8})(160 \mathrm{mg}, 0.33 \mathrm{mmol})$ to yield benzyl ((4acetamidophenyl)(diphenoxyphosphoryl)methyl)carbamate (110 mg, $0.20 \mathrm{mmol}, 63 \%$ yield) as a white 
solid. ${ }^{1} \mathrm{H}$ NMR (400 MHz, Methanol- $\left.d_{4}\right)$ d: 7.52 - 7.43 (m, 2H), 7.38 - 7.31 (m, 4H), 7.30 - 7.15 (m, 9H), $7.14-7.10(\mathrm{~m}, 4 \mathrm{H}), 5.65-5.51(\mathrm{~m}, 1 \mathrm{H}), 5.02-4.97(\mathrm{~m}, 2 \mathrm{H}), 2.15$ (s, 3H). MS (ESI) $m / z 531.7$ $[\mathrm{M}+\mathrm{H}]^{+}$.

Benzyl ((4-(3,3-dimethylureido)phenyl)(diphenoxyphosphoryl)methyl)carbamate (123). General procedure $\mathbf{J}$ with dimethylcarbamoylchloride $(87 \mathrm{mg}, 0.81 \mathrm{mmol}, 2.2 \mathrm{eq}$ ) and benzyl (4aminophenyl)(diphenoxyphosphoryl)methylcarbamate (58) $(180 \mathrm{mg}, 0.37 \mathrm{mmol})$ to yield benzyl ((4(3,3-dimethylureido)phenyl)(diphenoxyphosphoryl)methyl)carbamate (30 mg, $0.05 \mathrm{mmol}, 15 \%$ yield) as a white solid. ${ }^{1} \mathrm{H}$ NMR (400 MHz, $\left.\mathrm{CDCl}_{3}\right)$ 8: 7.42 (s, 3H), $7.06-7.41$ (m, 15H), $6.87-6.96(\mathrm{~m}$, 2H), $6.43(\mathrm{~s}, 1 \mathrm{H}), 5.87$ (d, $J=9.5 \mathrm{~Hz}, 1 \mathrm{H}), 5.55(\mathrm{dd}, J=9.5,22.0 \mathrm{~Hz}, 1 \mathrm{H}), 5.17$ (d, $J=12.0 \mathrm{~Hz}, 1 \mathrm{H}$ ), $5.08(\mathrm{~d}, J=12.0 \mathrm{~Hz}, 1 \mathrm{H}), 3.04(\mathrm{~s}, 6 \mathrm{H})$. MS (ESI) $\mathrm{m} / z 560.7[\mathrm{M}+\mathrm{H}]^{+}$.

Benzyl ((diphenoxyphosphoryl)(3-guanidinophenyl)methyl)carbamate 2,2,2-trifluoroacetate (124). Procedure and characterization consistent with previously reported data. ${ }^{62}$

Benzyl ((diphenoxyphosphoryl)(5-guanidinonaphthalen-1-yl)methyl)carbamate 2,2,2-

trifluoroacetate (125). General procedure I followed by general procedure $\mathbf{H}$ with benzyl ((5aminonaphthalen-1-yl)(diphenoxyphosphoryl)methyl)carbamate (119) $(440 \mathrm{mg}, 0.82 \mathrm{mmol})$ ) to yield benzyl ((diphenoxyphosphoryl)(5-guanidinonaphthalen-1-yl)methyl)carbamate $2,2,2-$ trifluoroacetate2,2,2-trifluoroacetate (69 mg, $0.10 \mathrm{mmol}, 12 \%$ yield). ${ }^{1} \mathrm{H}$ NMR (400 MHz, Methanol$\left.d_{4}\right) \delta: 8.39(\mathrm{~d}, J=8.5 \mathrm{~Hz}, 1 \mathrm{H}), 8.13-8.01(\mathrm{~m}, 2 \mathrm{H}), 7.72-7.65(\mathrm{~m}, 2 \mathrm{H}), 7.58(\mathrm{~d}, J=7.0 \mathrm{~Hz}, 1 \mathrm{H}), 7.41$ $-7.12(\mathrm{~m}, 11 \mathrm{H}), 7.08-7.02(\mathrm{~m}, 2 \mathrm{H}), 6.93-6.87(\mathrm{~m}, 2 \mathrm{H}), 6.58(\mathrm{~d}, J=23.0 \mathrm{~Hz}, 1 \mathrm{H}), 5.14(\mathrm{dd}, J=48.0$ $12.5 \mathrm{~Hz}, 2 \mathrm{H})$. MS (ESI) m/z 581.2 [M+H] ${ }^{+}$. HRMS: Calc: 581.20 Found: $581.1940[\mathrm{M}+\mathrm{H}]^{+}$.

\section{Benzyl (1-(diphenoxyphosphoryl)-3-(4-(methylsulfonamido)phenyl)propyl)carbamate (126).}

General procedure $\mathbf{J}$ with methanesulfonylchloride $(0.42 \mathrm{~mL}, 5.43 \mathrm{mmol}, 1.2 \mathrm{eq})$ and benzyl (3-(4aminophenyl)-1-(diphenoxyphosphoryl)propyl)carbamate (120) (2.55 g, $4.94 \mathrm{mmol}$ ) to yield benzyl (1(diphenoxyphosphoryl)-3-(4-(methylsulfonamido)phenyl)propyl)carbamate (1.62 g, $2.72 \mathrm{mmol}, 55 \%$ yield) as an colourless foam. ${ }^{1} \mathrm{H}$ NMR $\left(400 \mathrm{MHz}\right.$, Acetone- $\left.d_{6}\right) \delta: 8.49(\mathrm{~s}, 1 \mathrm{H}), 7.58-7.13(\mathrm{~m}, 19 \mathrm{H})$, $7.08(\mathrm{~d}, J=10.0 \mathrm{~Hz}, 1 \mathrm{H}), 5.23-4.91(\mathrm{~m}, 2 \mathrm{H}), 4.44(\mathrm{dtt}, J=28.0,25.0,12.5 \mathrm{~Hz}, 1 \mathrm{H}), 3.01-2.80(\mathrm{~m}$, 4H), $2.79-2.65(\mathrm{~m}, 1 \mathrm{H}), 2.42-2.09(\mathrm{~m}, 2 \mathrm{H}) .{ }^{13} \mathrm{C}$ NMR (100 MHz, Acetone- $\left.d_{6}\right) \delta: 157.1,151.6,151.3$, $138.1,138.0,137.5,130.5,130.4,129.2,128.8,126.0,125.9,121.6,121.3,67.2,49.0$ (d, 
$\left.1 \quad J_{\mathrm{CP}}=159.0 \mathrm{~Hz}\right), 39.2,32.2,31.9 . \mathrm{MS}(\mathrm{ESI}) \mathrm{m} / z$ 595.1 [M+H] $]^{+}$. HRMS: Calc: 595.17 Found: 595.1647

$2[\mathrm{M}+\mathrm{H}]^{+}$.

\section{Benzyl}

((4-(dimethylamino)-3(methylsulfonamido)phenyl)(diphenoxyphosphoryl)methyl)carbamate (127). General procedure J with methanesulfonyl chloride $(0.05 \mathrm{~mL}, 0.64 \mathrm{mmol}, 1.2 \mathrm{eq})$ and benzyl ((3-amino-4(dimethylamino)phenyl)(diphenoxyphosphoryl)methyl)carbamate (121) $(310 \mathrm{mg}, 0.58 \mathrm{mmol})$ to yield benzyl ((4-(dimethylamino)-3-(methylsulfonamido)phenyl)(diphenoxyphosphoryl)methyl)carbamate as a colourless foam. ${ }^{1} \mathrm{H}$ NMR $(400 \mathrm{MHz}, \mathrm{CDCl} 3) \delta: 7.75(\mathrm{~s}, 1 \mathrm{H}), 7.59(\mathrm{~s}, 1 \mathrm{H}), 7.22-6.95(\mathrm{~m}, 15 \mathrm{H})$, $6.91-6.77(\mathrm{~m}, 2 \mathrm{H}), 6.06(\mathrm{dd}, J=10.0,4.5 \mathrm{~Hz}, 1 \mathrm{H}), 5.47(\mathrm{dt}, J=15.0,7.5 \mathrm{~Hz}, 1 \mathrm{H}), 5.13-4.91(\mathrm{~m}, 2 \mathrm{H})$, 2.79 (s, 3H), 2.52 (s, 6H). ${ }^{13} \mathrm{C}$ NMR (100 MHz, CDCl3) $\delta: 155.6,150.2,142.85,136.0,133.6,131.6$, $129.9,129.7,128.6,128.4,128.3,125.6,125.4,123.6,121.7,120.5,120.4,115.8,67.6,52.7$ (d, $\left.J_{\mathrm{CP}}=158.0 \mathrm{~Hz}\right), 44.9,39.3 . \mathrm{MS}(\mathrm{ESI}) \mathrm{m} / \mathrm{z} 610.3[\mathrm{M}+\mathrm{H}]^{+}$.

Methyl ((diphenoxyphosphoryl)(3-(trifluoromethyl)phenyl)methyl)carbamate (128). General procedure C with 2-(4-(trifluoromethyl)phenyl)acetaldehyde (7) (290 mg, $1.54 \mathrm{mmol}$ ) and methyl carbamate (116 mg, $1.54 \mathrm{mmol}, 1 \mathrm{eq})$ to give methyl (1-(diphenoxyphosphoryl)-2-(4(trifluoromethyl)phenyl)ethyl)carbamate (150 mg, $0.31 \mathrm{mmol}, 20 \%$ yield). ${ }^{1} \mathrm{H}$ NMR (400 MHz, DMSO- $\left.d_{6}\right) \delta: 8.09(\mathrm{~d}, J=9.5 \mathrm{~Hz}, 1 \mathrm{H}), 7.68(\mathrm{~d}, J=8.0 \mathrm{~Hz}, 2 \mathrm{H}), 7.57(\mathrm{t}, J=9.5 \mathrm{~Hz}, 2 \mathrm{H}), 7.44-7.36(\mathrm{~m}$, 5H), $7.22(\mathrm{ddd}, J=17.0,8.0,2.0 \mathrm{~Hz}, 7 \mathrm{H}), 4.63-4.47(\mathrm{~m}, 1 \mathrm{H}), 3.43(\mathrm{~s}, 3 \mathrm{H}), 3.41-3.37(\mathrm{~m}, 1 \mathrm{H}), 3.31$ $(\mathrm{s}, 1 \mathrm{H}), 3.16-3.00(\mathrm{~m}, 1 \mathrm{H}) .{ }^{13} \mathrm{C}$ NMR $\left(100 \mathrm{MHz}, \mathrm{DMSO}-d_{6}\right) \delta: 157.4,150.9,143.0,131.0,130.9$, 128.3, 126.4, 126.0, 124.0, 121.4, 52.8, $50.6\left(\mathrm{~d}, J_{\mathrm{CP}}=159.0 \mathrm{~Hz}\right), 35.0 . \mathrm{MS}(\mathrm{ESI}) \mathrm{m} / z$ 480.1 $[\mathrm{M}+\mathrm{H}]^{+}$. HRMS: Calc: 480.12 Found: $480.1179[\mathrm{M}+\mathrm{H}]^{+}$.

\section{Benzyl (1-(bis(4-acetamidophenoxy)phosphoryl)-2-(4-(trifluoromethyl)phenyl)ethyl) carbamate} (129). General procedure $\mathbf{C}$ with 2-(4-(trifluoromethyl)phenyl)acetaldehyde (7) (642 mg, $3.41 \mathrm{mmol}$ ), and tris(4-acetamidophenyl) phosphite $(1.81 \mathrm{~g}, 3.75 \mathrm{mmol}, 1.1 \mathrm{eq})$ to give benzyl (1-(bis(4acetamidophenoxy)phosphoryl)-2-(4-(trifluoromethyl)phenyl)ethyl) carbamate (51 mg, $0.08 \mathrm{mmol}, 2 \%$ yield). ${ }^{1} \mathrm{H}$ NMR (400 MHz, Acetone- $\left.d_{6}\right) \delta: 9.22(\mathrm{~s}, 2 \mathrm{H}), 7.63(\mathrm{dt}, J=12.5,5.0 \mathrm{~Hz}, 8 \mathrm{H}), 7.34-7.26(\mathrm{~m}$, 3H), $7.21(\mathrm{dt}, J=5.0,4.0 \mathrm{~Hz}, 2 \mathrm{H}), 7.18-7.10(\mathrm{~m}, 4 \mathrm{H}), 5.07$ - $4.88(\mathrm{~m}, 2 \mathrm{H}), 4.82-4.64(\mathrm{~m}, 1 \mathrm{H}), 3.58-$ $3.44(\mathrm{~m}, 1 \mathrm{H}), 3.21(\mathrm{ddd}, J=14.0,12.0,8.5 \mathrm{~Hz}, 1 \mathrm{H}), 2.05(\mathrm{~d}, J=2.0 \mathrm{~Hz}, 6 \mathrm{H}) .{ }^{13} \mathrm{C} \mathrm{NMR}(100 \mathrm{MHz}$, 
$1 \quad$ Acetone- $\left.d_{6}\right) \delta: 168.7,156.8,146.7,146.5,142.9,137.9,137.84,137.7,130.9,129.1,128.6,128.4$, 126.1, 126.0, 124.2, 121.7, 121.4, 120.9, 66.9, $50.6\left(\mathrm{~d}, J_{\mathrm{CP}}=159.0 \mathrm{~Hz}\right), 35.7,24.6 . \mathrm{MS}(\mathrm{ESI}) \mathrm{m} / z 670.2$ $[\mathrm{M}+\mathrm{H}]^{+}$. HRMS: Calc: 670.19 Found: $670.1912[\mathrm{M}+\mathrm{H}]^{+}$.

Methyl (1-(bis(4-acetamidophenoxy)phosphoryl)-2-(4-(trifluoromethyl)phenyl)ethyl)carbamate (130). General procedure $\mathbf{C}$ with 2-(4-(trifluoromethyl)phenyl)acetaldehyde (7) (376 mg, $2.00 \mathrm{mmol}$ ), methyl carbamate $(150 \mathrm{mg}, 2.00 \mathrm{mmol}, 1 \mathrm{eq})$ and tris(4-acetamidophenyl) phosphite (1.05 g, $2.20 \mathrm{mmol}, \quad 1.1 \mathrm{eq}) \quad$ to give methyl (1-(bis(4-acetamidophenoxy)phosphoryl)-2-(4(trifluoromethyl)phenyl)ethyl)carbamate ( $8 \mathrm{mg}, 0.01 \mathrm{mmol}, 1 \%$ yield). ${ }^{1} \mathrm{H}$ NMR (400 MHz, DMSO$\left.d_{6}\right) \delta: 9.04(\mathrm{~s}, 2 \mathrm{H}), 7.62-7.49(\mathrm{~m}, 6 \mathrm{H}), 7.42-7.12(\mathrm{~m}, 4 \mathrm{H}), 7.11-6.94(\mathrm{~m}, 2 \mathrm{H}), 6.73(\mathrm{~m}, 1 \mathrm{H}), 4.73$ - 4.59 (m, 1H), $3.43(\mathrm{~s}, 3 \mathrm{H}), 3.52-3.40(\mathrm{~m}, 1 \mathrm{H}), 3.28(\mathrm{ddd}, J=13.5,12.5,8.0 \mathrm{~Hz}, 1 \mathrm{H}), 2.03(\mathrm{~s}, 6 \mathrm{H}) . \mathrm{MS}$ (ESI) $m / z, 594.1[\mathrm{M}+\mathrm{H}]^{+}$.

Methyl ((diphenoxyphosphoryl)(3-nitrophenyl)methyl)carbamate (131). General procedure $\mathbf{C}$ with 3-nitrobenzaldehyde (500 mg, $3.31 \mathrm{mmol})$ and methyl carbamate (248 mg, $3.31 \mathrm{mmol})$ to give methyl ((diphenoxyphosphoryl)(3-nitrophenyl)methyl)carbamate (1.04 g, $2.13 \mathrm{mmol}, 64 \%$ yield). ${ }^{1} \mathrm{H}$ NMR $\left(400 \mathrm{MHz}\right.$, Acetone- $\left.d_{6}\right) \delta: 8.61(\mathrm{dd}, J=4.0,2.2 \mathrm{~Hz}, 1 \mathrm{H}), 8.24(\mathrm{dt}, J=8.0,2.5 \mathrm{~Hz}, 1 \mathrm{H}), 8.13(\mathrm{~d}$, $J=7.5 \mathrm{~Hz}, 1 \mathrm{H}), 7.95(\mathrm{~d}, J=8.5 \mathrm{~Hz}, 1 \mathrm{H}), 7.73(\mathrm{t}, J=8.0 \mathrm{~Hz}, 1 \mathrm{H}), 7.34(\mathrm{ddd}, J=8.0,4.0,1.5 \mathrm{~Hz}, 4 \mathrm{H})$, $7.23-7.14(\mathrm{~m}, 4 \mathrm{H}), 7.14-7.09(\mathrm{~m}, 2 \mathrm{H}), 5.87(\mathrm{dd}, J=23.5,10.0 \mathrm{~Hz}, 1 \mathrm{H}), 3.66(\mathrm{~s}, 3 \mathrm{H}) . \mathrm{MS}(\mathrm{ESI}) \mathrm{m} / z$ $443.2[\mathrm{M}+\mathrm{H}]^{+}$.

Benzo[d][1,3]dioxol-5-ylmethyl ((diphenoxyphosphoryl)(3-nitrophenyl)methyl)carbamate (132). General procedure $\mathbf{C}$ with 3-nitrobenzaldehyde $(200 \mathrm{mg}, 1.32 \mathrm{mmol})$ and benzo[d][1,3]dioxol-5ylmethyl carbamate $(258 \mathrm{mg}, \quad 1.32 \mathrm{mmol})$ to yield benzo[d][1,3]dioxol-5-ylmethyl ((diphenoxyphosphoryl)(3-nitrophenyl)methyl)carbamate (250 mg, $0.39 \mathrm{mmol}, 30 \%$ yield). MS (ESI) $m / z 585.2[\mathrm{M}+\mathrm{Na}]^{+}$.

Benzyl ((bis(4-acetamidophenoxy)phosphoryl)(3-nitrophenyl)methyl)carbamate (133). General procedure $\mathbf{C}$ with 3-nitrobenzaldehyde (1.00 g, $6.62 \mathrm{mmol})$ and tris(4-acetamidophenyl) phosphite (7.46 g, 7.28 mmol) to yield benzyl ((bis(4-acetamidophenoxy)phosphoryl)(3nitrophenyl)methyl)carbamate (134 mg, $0.21 \mathrm{mmol}, 3 \%$ yield). MS (ESI) $\mathrm{m} / z 633.2=[\mathrm{M}+\mathrm{H}]^{+}$. 
Methyl ((bis(4-acetamidophenoxy)phosphoryl)(3-nitrophenyl)methyl)carbamate (134). General procedure $\mathbf{C}$ with 3-nitrobenzaldehyde (1.00 g, $6.62 \mathrm{mmol})$, methyl carbamate (497 mg, $6.62 \mathrm{mmol}$ ) and tris(4-acetamidophenyl) phosphite $(3.50 \mathrm{~g}, \quad 7.28 \mathrm{mmol})$ to give methyl ((bis(4acetamidophenoxy)phosphoryl)(3-nitrophenyl)methyl)carbamate (480 mg, $0.73 \mathrm{mmol}, 11 \%$ yield). MS (ESI) $m / z 443.2[\mathrm{M}+\mathrm{H}]^{+}$.

Methyl ((3-aminophenyl)(diphenoxyphosphoryl)methyl)carbamate (135). General procedure K with pent-4-yn-1-yl ((diphenoxyphosphoryl)(4-nitrophenyl)methyl)carbamate (131) (2.24 g, $4.54 \mathrm{mmol})$ to yield pent-4-yn-1-yl ((4-aminophenyl)(diphenoxyphosphoryl)methyl)carbamate (2.04 g, $4.40 \mathrm{mmol}, 97 \%$ yield). ${ }^{1} \mathrm{H}$ NMR (400 MHz, DMSO- $\left.d_{6}\right) \delta: 8.09$ (d, $\left.J=9.5 \mathrm{~Hz}, 1 \mathrm{H}\right), 7.68(\mathrm{~d}, J=8.0$ $\mathrm{Hz}, 2 \mathrm{H}), 7.57(\mathrm{t}, J=9.5 \mathrm{~Hz}, 2 \mathrm{H}), 7.44-7.36(\mathrm{~m}, 5 \mathrm{H}), 7.22(\mathrm{ddd}, J=17.0,8.0,2.0 \mathrm{~Hz}, 7 \mathrm{H}), 4.63-4.47$ $(\mathrm{m}, 1 \mathrm{H}), 3.43(\mathrm{~s}, 3 \mathrm{H}), 3.41-3.37(\mathrm{~m}, 1 \mathrm{H}), 3.31(\mathrm{~s}, 1 \mathrm{H}), 3.16-3.00(\mathrm{~m}, 1 \mathrm{H}) .{ }^{13} \mathrm{C} \mathrm{NMR}(100 \mathrm{MHz}$, DMSO- $\left.d_{6}\right) \delta: 157.4,150.9,143.0,131.0,130.9,128.3,126.4,126.0,124.0,121.4,52.8,50.6(\mathrm{~d}$, $\left.J_{\mathrm{CP}}=159.0 \mathrm{~Hz}\right), 35.0 . \mathrm{MS}(\mathrm{ESI}) \mathrm{m} / z$ 480.1 $[\mathrm{M}+\mathrm{H}]^{+}$. HRMS: Calc: 413.13 Found: $413.1256[\mathrm{M}+\mathrm{H}]^{+}$.

\section{Benzo[d][1,3]dioxol-5-ylmethyl}

((3-aminophenyl)(diphenoxyphosphoryl)methyl)carbamate (136). General procedure $\mathbf{K}$ with benzo[d][1,3]dioxol-5-ylmethyl ((diphenoxyphosphoryl)(3nitrophenyl)methyl)carbamate (132) (250 mg, $0.44 \mathrm{mmol})$ to yield benzo[d][1,3]dioxol-5-ylmethyl ((3aminophenyl)(diphenoxyphosphoryl)methyl)carbamate (40 mg, 0.08 mmol, $17 \%$ yield. ${ }^{1} \mathrm{H}$ NMR $\left(400 \mathrm{MHz}\right.$, Acetone- $\left.d_{6}\right) \delta: 7.59(\mathrm{dd}, \mathrm{J}=58.0,10.0 \mathrm{~Hz}, 1 \mathrm{H}), 7.37-7.23(\mathrm{~m}, 4 \mathrm{H}), 7.22$ - $6.97(\mathrm{~m}, 7 \mathrm{H})$, $6.96-6.84(\mathrm{~m}, 4 \mathrm{H}), 6.84-6.76(\mathrm{~m}, 1 \mathrm{H}), 6.67-6.60(\mathrm{~m}, 1 \mathrm{H}), 5.99(\mathrm{~d}, J=1.0 \mathrm{~Hz}, 2 \mathrm{H}), 5.56(\mathrm{ddd}$, $J=58.0,22.0,10.0 \mathrm{~Hz}, 1 \mathrm{H}), 5.11-4.90(\mathrm{~m}, 2 \mathrm{H}), 4.71(\mathrm{~s}, 2 \mathrm{H}) .{ }^{13} \mathrm{C}$ NMR $\left(100 \mathrm{MHz}\right.$, Acetone- $\left.d_{6}\right) \delta$ : $156.8,153.0,151.4,149.5,148.6,148.4,136.2,131.6,130.4,130.0,125.9,122.8,121.3,120.2,117.4$, 115.1, 109.6, 108.7, 102.0, 67.3, $54.2\left(\mathrm{~d}, J_{\mathrm{CP}}=158.0 \mathrm{~Hz}\right) . \mathrm{MS}(\mathrm{ESI}) \mathrm{m} / \mathrm{z} 533.1[\mathrm{M}+\mathrm{H}]^{+}$.

Benzyl ((3-aminophenyl)(bis(4-acetamidophenoxy)phosphoryl)methyl)carbamate (137). General procedure $\mathbf{K}$ with benzyl ((bis(4-acetamidophenoxy) phosphoryl)(3-nitrophenyl)methyl)carbamate (133) $\quad(130 \quad \mathrm{mg}, \quad 0.21 \mathrm{mmol}) \quad$ to $\quad$ yield benzyl ((3-aminophenyl)(bis(4acetamidophenoxy)phosphoryl)methyl)carbamate (40 mg, 0,07 mmol, 32\% yield). ${ }^{1} \mathrm{H}$ NMR (400 MHz, Acetone- $\left.d_{6}\right) \delta: 9.22(\mathrm{~d}, J=4.0 \mathrm{~Hz}, 2 \mathrm{H}), 7.78-7.66(\mathrm{~m}, 1 \mathrm{H}), 7.54(\mathrm{dd}, J=12.5,6.0 \mathrm{~Hz}, 4 \mathrm{H}), 7.39-7.28$ $(\mathrm{m}, 6 \mathrm{H}), 7.04(\mathrm{dt}, J=17.0,8.0 \mathrm{~Hz}, 3 \mathrm{H}), 6.94-6.87(\mathrm{~m}, 3 \mathrm{H}), 6.67(\mathrm{~d}, J=2.0 \mathrm{~Hz}, 1 \mathrm{H}), 6.65(\mathrm{~d}, J=7.5$ 
$\mathrm{Hz}, 1 \mathrm{H}), 5.63-5.49(\mathrm{~m}, 1 \mathrm{H}), 5.11(\mathrm{ddd}, J=34.5,12.4,3.0 \mathrm{~Hz}, 2 \mathrm{H}), 4.72(\mathrm{~s}, 1 \mathrm{H}), 2.02(\mathrm{~d}, J=2.9 \mathrm{~Hz}$, 6H). ${ }^{13} \mathrm{C}$ NMR (100 MHz, Acetone- $\left.d_{6}\right) \delta: 168.9,156.8,153.0,149.5,146.7,137.7,136.3,130.0,129.9$, $129.2,128.8,123.7,121.5,120.9,120.4,120.3,117.5,115.3,115.1,67.4,54.8\left(\mathrm{~d}, J_{\mathrm{CP}}=156.5 \mathrm{~Hz}\right)$, 53.4, 24.2. MS (ESI) $\mathrm{m} / \mathrm{z} 603.2[\mathrm{M}+\mathrm{H}]^{+}$.

\section{Methyl ((3-aminophenyl)(bis(4-acetamidophenoxy)phosphoryl)methyl)carbamate (138). General} procedure $\mathbf{K}$ with methyl ((bis(4-acetamidophenoxy)phosphoryl)(3-nitrophenyl)methyl)carbamate (134) $\quad(480 \quad \mathrm{mg}, \quad 0.86 \quad \mathrm{mmol}) \quad$ to yield methyl ((3-aminophenyl)(bis(4acetamidophenoxy)phosphoryl)methyl)carbamate (135 mg, $0.26 \mathrm{mmol}, 30 \%$ yield). ${ }^{1} \mathrm{H}$ NMR $\left(400 \mathrm{MHz}, \mathrm{CD}_{3} \mathrm{CN}\right) \delta: 8.38(\mathrm{~d}, J=6.5 \mathrm{~Hz}, 1 \mathrm{H}), 7.52-7.42(\mathrm{~m}, 4 \mathrm{H}), 7.10(\mathrm{td}, J=8.0,1.0 \mathrm{~Hz}, 1 \mathrm{H}), 7.02$ - $6.97(\mathrm{~m}, 2 \mathrm{H}), 6.92-6.86(\mathrm{~m}, 2 \mathrm{H}), 6.79(\mathrm{~s}, 1 \mathrm{H}), 6.78-6.76(\mathrm{~m}, 2 \mathrm{H}), 6.73(\mathrm{~m}, 1 \mathrm{H}), 6.63-6.59(\mathrm{~m}, 1 \mathrm{H})$, $5.38(\mathrm{dd}, J=22.5,10.0 \mathrm{~Hz}, 1 \mathrm{H}), 3.63(\mathrm{~s}, 3 \mathrm{H}), 2.01(\mathrm{t}, J=3.5 \mathrm{~Hz}, 6 \mathrm{H}) .{ }^{13} \mathrm{C} \mathrm{NMR}\left(100 \mathrm{MHz}, \mathrm{CD}_{3} \mathrm{CN}\right)$ $\delta: 169.5,157.2,149.3,146.6,137.5,136.3,130.40,121.7,121.35,117.75,115.4,115.0,53.9(\mathrm{~d}$, $\left.J_{\mathrm{CP}}=156.5 \mathrm{~Hz}\right), 53.2,24.2 . \mathrm{MS}(\mathrm{ESI}) \mathrm{m} / z 527.2[\mathrm{M}+\mathrm{H}]^{+}$.

Methyl ((3-cyanophenyl)(diphenoxyphosphoryl)methyl)carbamate (139). General procedure C with 3-cyanobenzaldehyde ( $800 \mathrm{mg}, 6.10 \mathrm{mmol})$ and methyl carbamate $(458 \mathrm{mg}, 6.10 \mathrm{mmol})$, to yield methyl ((3-cyanophenyl) (diphenoxyphosphoryl)methyl)carbamate (2.58 g, $6.11 \mathrm{mmol}, 99 \%$ yield). ${ }^{1} \mathrm{H}$ NMR (400 MHz, DMSO-d $\left.)\right) \delta: 8.84(\mathrm{~d}, J=10.0 \mathrm{~Hz}, 1 \mathrm{H}), 8.14(\mathrm{~d}, J=1.5 \mathrm{~Hz}, 1 \mathrm{H}), 8.00$ (d, $J=8.0 \mathrm{~Hz}, 1 \mathrm{H}), 7.87-7.82(\mathrm{~m}, 1 \mathrm{H}), 7.63(\mathrm{t}, J=8.0 \mathrm{~Hz}, 1 \mathrm{H}), 7.37(\mathrm{dd}, J=16.0,7.5 \mathrm{~Hz}, 4 \mathrm{H}), 7.21(\mathrm{td}$, $J=7.5,3.5 \mathrm{~Hz}, 2 \mathrm{H}), 7.08(\mathrm{~d}, J=8.5 \mathrm{~Hz}, 2 \mathrm{H}), 7.03-6.98(\mathrm{~m}, 2 \mathrm{H}), 5.77(\mathrm{dd}, J=23.0,10.5 \mathrm{~Hz}, 1 \mathrm{H})$, $3.61(\mathrm{~s}, 3 \mathrm{H})$. MS (ESI) $m / z 423.2[\mathrm{M}+\mathrm{H}]^{+}$.

Benzyl ((bis(4-acetamidophenoxy)phosphoryl)(3-cyanophenyl)methyl)carbamate (140). General procedure $\mathbf{C}$ with 3-cyanobenzaldehyde $(3.00 \mathrm{~g}, 22.9 \mathrm{mmol})$ and tris(4-acetamidophenyl) phosphite (28.7 g, 25.2 $\mathrm{mmol})$ to give benzyl ((bis(4-acetamidophenoxy)phosphoryl)(3cyanophenyl)methyl)carbamate (4.13 g, $5.12 \mathrm{mmol}, 22 \%$ yield). MS (ESI) $\mathrm{m} / \mathrm{z} 613.3=[\mathrm{M}+\mathrm{H}]^{+}$.

Methyl ((bis(4-acetamidophenoxy)phosphoryl)(3-cyanophenyl)methyl)carbamate (141). General procedure $\mathbf{C}$ with 3-cyanobenzaldehyde (3.00 g, $22.8 \mathrm{mmol})$, methyl carbamate $(1.72 \mathrm{~g}, 22.8 \mathrm{mmol})$ and tris(4-acetamidophenyl) phosphite $(30.1 \mathrm{~g}, 25.2 \mathrm{mmol})$ to yield methyl ((bis(4- 
$5 \quad(1.00$

acetamidophenoxy)phosphoryl)(3-cyanophenyl)methyl) carbamate (2.13 g, 3.96 mmol, 17\% yield). MS (ESI) $m / z$. $537.2=[\mathrm{M}+\mathrm{H}]^{+}$

Methyl ((3-(N-acetoxycarbamimidoyl)phenyl)(diphenoxyphosphoryl)methyl)carbamate (142).

General procedure $\mathbf{C}$ with methyl ((3-cyanophenyl)(diphenoxyphosphoryl)methyl)carbamate (139) $(1.00 \mathrm{~g}, \quad 2.37 \mathrm{mmol}) \quad$ to $\quad$ yield $\quad$ methyl $\quad((3-(N-)$ acetoxycarbamimidoyl)phenyl)(diphenoxyphosphoryl)methyl)carbamate (2.34 g, $2.82 \mathrm{mmol})$. MS (ESI) $m / z 498.2[\mathrm{M}+\mathrm{H}]^{+}$

Benzyl (3- $(N$-acetoxycarbamimidoyl $)$ phenyl $)($ bis(4-acetamidophenoxy $)$ phosphoryl) methyl)carbamate (143). General procedure L with benzyl ((bis(4-acetamidophenoxy)phosphoryl)(3cyanophenyl)methyl) carbamate $\quad(\mathbf{1 4 0}) \quad(4.13 \mathrm{~g}, 5.12 \mathrm{mmol})$ to yield benzyl $\quad((3-(N-$ acetoxycarbamimidoyl)phenyl)(bis(4-acetamidophenoxy)phosphoryl)methyl)carbamate $\quad(950 \quad \mathrm{mg}$, $1.38 \mathrm{mmol}, 27 \%$ yield). MS (ESI) $\mathrm{m} / \mathrm{z} 688.4[\mathrm{M}+\mathrm{H}]^{+}$.

Methyl ((3-(N-acetoxycarbamimidoyl)phenyl)(bis(4-acetamidophenoxy)phosphoryl) methyl)carbamate (144). General procedure L with methyl ((bis(4-acetamidophenoxy)phosphoryl)(3cyanophenyl)methyl) carbamate $\mathbf{( 1 4 1 )}(2.13 \mathrm{~g}, 3.96 \mathrm{mmol})$ to yield methyl $((3-(N-$ acetoxycarbamimidoyl)phenyl)(bis(4-acetamidophenoxy)phosphoryl)methyl)carbamate $\quad(3.70 \quad \mathrm{~g}$, $3.75 \mathrm{mmol}, 95 \%$ yield). MS (ESI) $\mathrm{m} / z 612.3=[\mathrm{M}+\mathrm{H}]^{+}$.

Methyl ((3-carbamimidoylphenyl)(diphenoxyphosphoryl)methyl)carbamate (145). General $\begin{array}{llll}\text { procedure } & \text { M } & \text { with } & \text { methyl }\end{array}$ acetoxycarbamimidoyl)phenyl)(diphenoxyphosphoryl)methyl)carbamate (142) (2.24 g, $2.79 \mathrm{mmol})$ to yield methyl ((3-carbamimidoylphenyl)(diphenoxyphosphoryl)methyl)carbamate (88 mg, $0.20 \mathrm{mmol}$, 7\% yield). ${ }^{1} \mathrm{H}$ NMR (400 MHz, Methanol-d 4 ) $\delta: 7.99(\mathrm{~d}, J=7.5 \mathrm{~Hz}, 1 \mathrm{H}), 7.95(\mathrm{~s}, 1 \mathrm{H}), 7.80(\mathrm{~d}, J=24.5$, $12.5 \mathrm{~Hz}, 1 \mathrm{H}), 7.69(\mathrm{t}, J=8.0 \mathrm{~Hz}, 1 \mathrm{H}), 7.34(\mathrm{td}, J=8.0,3.5 \mathrm{~Hz}, 4 \mathrm{H}), 7.22(\mathrm{t}, J=7.5 \mathrm{~Hz}, 2 \mathrm{H}), 7.05(\mathrm{dd}$, $J=22.5,8.5 \mathrm{~Hz}, 4 \mathrm{H}), 5.79(\mathrm{~d}, J=23.5 \mathrm{~Hz}, 1 \mathrm{H}), 3.71(\mathrm{~s}, 3 \mathrm{H}) .{ }^{13} \mathrm{C}$ NMR $\left(100 \mathrm{MHz}, \mathrm{Methanol}-d_{4}\right) \delta$ : $168.2,158.8,151.4,137.3,134.7,131.0,130.4,129.2,129.0,127.0,121.5,54.6\left(\mathrm{~d}, J_{\mathrm{CP}}=158.0 \mathrm{~Hz}\right)$, 53.4. MS (ESI) $m / z 440.4[\mathrm{M}+\mathrm{H}]^{+}$.

Benzyl ((bis(4-acetamidophenoxy)phosphoryl)(3-carbamimidoylphenyl)methyl) carbamate (146). General procedure $\mathbf{M}$ with benzyl ((3-(N-acetoxycarbamimidoyl)phenyl)(bis(4- 
acetamidophenoxy)phosphoryl) methyl)carbamate (143) $(950 \mathrm{mg}, 1.38 \mathrm{mmol})$ to yield benzyl ((bis(4acetamidophenoxy)phosphoryl)(3-carbamimidoylphenyl)methyl)carbamate (172 mg, $0.273 \mathrm{mmol}$, 20\% yield). ${ }^{1} \mathrm{H}$ NMR (400 MHz, Methanol- $\left.d_{4}\right) \delta: 7.96(\mathrm{~d}, J=7.5 \mathrm{~Hz}, 1 \mathrm{H}), 7.93(\mathrm{~s}, 1 \mathrm{H}), 7.79$ (d, $J=7.5 \mathrm{~Hz}, 1 \mathrm{H}), 7.66(\mathrm{t}, J=8.0 \mathrm{~Hz}, 1 \mathrm{H}), 7.51-7.46(\mathrm{~m}, 4 \mathrm{H}), 7.39-7.30(\mathrm{~m}, 5 \mathrm{H}), 6.95(\mathrm{dd}, J=22.0$, $8.5 \mathrm{~Hz}, 4 \mathrm{H}), 5.78(\mathrm{~d}, J=23.0 \mathrm{~Hz}, 1 \mathrm{H}), 5.14(\mathrm{dd}, J=49.5,12.5 \mathrm{~Hz}, 2 \mathrm{H}), 2.10(\mathrm{~s}, 6 \mathrm{H}) .{ }^{13} \mathrm{C} \mathrm{NMR}(100$ MHz, Methanol- $\left.\left.d_{4}\right) \delta: 171.6,168.4,158.2,147.0\right), 137.8,137.2,134.6,131.0,130.6,129.5,129.3$, $129.1,129.0,122.3,121.7,68.4,53.7\left(\mathrm{~d}, J_{\mathrm{CP}}=158.5 \mathrm{~Hz}\right), 23.7 . \mathrm{MS}(\mathrm{ESI}) \mathrm{m} / z 630.3[\mathrm{M}+\mathrm{H}]^{+}$.

Methyl ((bis(4-acetamidophenoxy)phosphoryl)(3-carbamimidoylphenyl)methyl) carbamate (147). General procedure $\mathbf{M}$ with methyl ((3-(N-acetylcarbamimidoyl)phenyl)(bis(4acetamidophenoxy)phosphoryl)methyl) carbamate (144) (3.70 g, $3.85 \mathrm{mmol})$ to yield methyl ((bis(4acetamidophenoxy)phosphoryl)(3-carbamimidoylphenyl)methyl)carbamate (190 mg, $0.34 \mathrm{mmol}, 9 \%$ yield). ${ }^{1} \mathrm{H}$ NMR (400 MHz, DMSO- $\left.d_{6}\right) \delta: 10.17(\mathrm{~s}, 3 \mathrm{H}), 9.44(\mathrm{~s}, 1 \mathrm{H}), 9.29(\mathrm{~s}, 1 \mathrm{H}), 8.80(\mathrm{~d}, J=10.0 \mathrm{~Hz}$, 1H), $8.06(\mathrm{~s}, 1 \mathrm{H}), 8.02(\mathrm{~d}, J=7.5 \mathrm{~Hz}, 1 \mathrm{H}), 7.83(\mathrm{~d}, J=7.0 \mathrm{~Hz}, 1 \mathrm{H}), 7.68(\mathrm{t}, J=8.0 \mathrm{~Hz}, 1 \mathrm{H}), 7.60-7.46$ (m, 4H), $6.98(\mathrm{dd}, J=26.5,8.5 \mathrm{~Hz}, 4 \mathrm{H}), 5.66(\mathrm{dd}, J=22.5,10.0 \mathrm{~Hz}, 1 \mathrm{H}), 3.61(\mathrm{~d}, J=10.5 \mathrm{~Hz}, 3 \mathrm{H})$, $2.03(\mathrm{~d}, J=0.5 \mathrm{~Hz}, 6 \mathrm{H}) .{ }^{13} \mathrm{C}$ NMR $\left(100 \mathrm{MHz}, \mathrm{DMSO}-d_{6}\right) \delta: 168.3,165.5,156.5,144.9,136.7,135.7$, 133.4, 129.3, 128.4, 128.1, 128.0, 120.5, 120.2, $52.2\left(\mathrm{~d}, J_{\mathrm{CP}}=157.0 \mathrm{~Hz}\right), 52.3,23.9 . \mathrm{MS}(\mathrm{ESI}) \mathrm{m} / z 554.3$ $=[\mathrm{M}+\mathrm{H}]^{+}$.

(S)-2-(((Benzyloxy)carbonyl)amino)-2-(3-nitrophenyl)acetic acid (148). Procedure and characterization consistent with previously reported data. ${ }^{63}$

(S)-Benzyl (2-amino-1-(3-nitrophenyl)-2-oxoethyl)carbamate (149). Procedure and characterization consistent with previously reported data. ${ }^{64}$

(S)-Benzyl (cyano(3-nitrophenyl)methyl)carbamate (150). General procedure $\mathbf{F}$ with $(S)$-benzyl (2amino-1-(3-nitrophenyl)-2-oxoethyl)carbamate (149) (1.92 g, $5.83 \mathrm{mmol}$ ) to yield (S)-benzyl (cyano(3nitrophenyl)methyl)carbamate (245 mg, $0.60 \mathrm{mmol}, 13 \%$ yield). MS (ESI) $\mathrm{m} / \mathrm{z} 312.2[\mathrm{M}+\mathrm{H}]^{+}$.

(S)-Benzyl ((3-aminophenyl)(cyano)methyl)carbamate (151). General procedure $\mathbf{K}$ with (S)-benzyl (cyano(3-nitrophenyl)methyl)carbamate (150) (245 mg, $0.79 \mathrm{mmol})$ to afford (S)-benzyl ((3aminophenyl)(cyano)methyl)carbamate (215 mg, $0.78 \mathrm{mmol}, 99 \%$ yield). ${ }^{1} \mathrm{H}$ NMR (400 MHz, CDCl3) $\delta: 7.44-7.31(\mathrm{~m}, 5 \mathrm{H}), 7.23-7.11(\mathrm{~m}, 1 \mathrm{H}), 6.83(\mathrm{~d}, J=7.5 \mathrm{~Hz}, 1 \mathrm{H}), 6.74(\mathrm{~d}, J=11.0 \mathrm{~Hz}, 1 \mathrm{H}), 6.69$ 
(ddd, $J=8.5,5.0,3.5 \mathrm{~Hz}, 1 \mathrm{H}), 5.74(\mathrm{~d}, J=8.5 \mathrm{~Hz}, 1 \mathrm{H}), 5.41-5.28(\mathrm{~m}, 1 \mathrm{H}), 5.16(\mathrm{~d}, J=17.5 \mathrm{~Hz}, 2 \mathrm{H})$, 4.04 - $3.68(\mathrm{~m}, 2 \mathrm{H}) .{ }^{13} \mathrm{C} \mathrm{NMR}\left(100 \mathrm{MHz}, \mathrm{CDCl}_{3}\right) \delta: 155.1,147.5,135.6,134.2,130.5,128.8,128.7$, 128.5, 117.7, 116.7, 116.2, 113.1, 68.0, 46.7. MS (ESI) $\mathrm{m} / z 282.1[\mathrm{M}+\mathrm{H}]^{+}$.

\section{BIOLOGICAL EVALUATION.}

Protein production. E. coli $\mathrm{ClpP}$ protein carrying a C-termial His 6 affinity tag was produced starting from pETDclpPec (ORF ECK0431). ${ }^{65}$ pETDclpPec was transformed into E. coli SG1146a strain $(\triangle \operatorname{lp} P)$ for overexpression. Overnight cultures were grown at $37{ }^{\circ} \mathrm{C}$ on an orbital shaker at $130 \mathrm{rpm}$, then diluted in fresh LB medium including $100 \mu \mathrm{g} / \mathrm{mL}$ ampicillin, and grown until an $\mathrm{OD}_{600}$ of 0.6 was reached. Induction was carried out in $5 \mathrm{~L}$ flasks by $1 \mathrm{mM}$ isopropyl $\beta$-D-1-thiogalactopyranoside at $30{ }^{\circ} \mathrm{C}$ at $180 \mathrm{rpm}$ over $5 \mathrm{~h}$. Cell lysis of cooled samples was conducted using Precellys Evolution (Bertin Technologies, France). Supernatant was applied to Ni-NTA (Sigma Aldrich, USA) followed by batchwise washing and elution steps, sequentially applying buffer $\mathrm{A}(\mathrm{pH}$ 7.6, $50 \mathrm{mM}$ Tris- $\mathrm{HCl}$ buffer, $150 \mathrm{mM} \mathrm{NaCl}, 10 \mathrm{mM}$ imidazole), buffer B (pH 7.6, $50 \mathrm{mM}$ Tris-HCl buffer, $150 \mathrm{mM} \mathrm{NaCl}, 20 \mathrm{mM}$ imidazole), buffer $\mathrm{C}$ (pH 7.6, $50 \mathrm{mM}$ Tris-HCl buffer, $150 \mathrm{mM} \mathrm{NaCl}, 500 \mathrm{mM}$ Imidazole) and buffer D (pH 7.6, 20 mM Tris-HCl buffer, $100 \mathrm{mM} \mathrm{NaCl}, 5 \mathrm{mM} \mathrm{MgCl}, 10 \%$ (v/v) glycerol). Purified ClpP protein was frozen in liquid nitrogen and stored at $-80{ }^{\circ} \mathrm{C}$. Protein purity and concentration were determined by SDS-PAGE and the Bradford assay, respectively.

Assay Development and Screening. A microplate screening assay with a fluorescence based readout was developed to measure ClpP proteolytic activity. The ClpP activity assay was performed with the fluorogenic substrate Suc-LY-AMC (Enzo Life Sciences, Germany) at $75 \mu \mathrm{M}$ and E. coli ClpP at $625 \mathrm{nM}$ in $100 \mathrm{mM} \mathrm{NaCl}$ and $100 \mathrm{mM}$ Hepes pH 7.5, 0.05\% Brij ${ }^{\circledR} 35$ (\#P1254, Sigma Aldrich, USA). Compound selectivity for ClpP was assessed by measuring the level of activity of the compounds in the presence of $40 \mathrm{nM}$ of alpha-chymotrypsin (\#C4129, Sigma-Aldrich, USA) and $100 \mu \mathrm{M}$ of Suc-LYAMC substrate, in a buffer containing $150 \mathrm{mM} \mathrm{NaCl}, 10 \mathrm{mM} \mathrm{CaCl}_{2}, 50 \mathrm{mM}$ Tris- $\mathrm{HCl}$ and $0.05 \% \mathrm{Brij}^{\circledR}$ 35. Assays were performed in 384-well black, flat-bottom microtiter plates (\#3820, Corning Inc., Corning, USA). All compounds were dissolved in 99.8\% DMSO (ROTIPURAN® CAS No.[67-68-5], Carl Roth GmbH, Germany), at a stock concentration of $10 \mathrm{mM}$. Compound serial dilutions were carried out in $1: 3$ or $1: 2$ dilutions and stored at $-20{ }^{\circ} \mathrm{C}$. Screening of compounds was conducted at a 
1 final compound concentration of $200 \mu \mathrm{M}$ in triplicates, with compound transfer carried out using acoustic liquid handling (Echo 550, Labcyte, USA). ClpP protein and compounds were incubated for 10 min at $30{ }^{\circ} \mathrm{C}$, followed by addition of the fluorescent substrate Suc-LY-AMC. The reaction was monitored by following the increase of fluorescence (excitation $350 \mathrm{~nm}$, emission $435 \mathrm{~nm}$ ) at $30{ }^{\circ} \mathrm{C}$ over $1 \mathrm{~h}$. Vehicle controls contained the same DMSO concentration (2\% v/v) without compound and chloromethyl ketone (Z-LY-CMK) (\#4016342, Bachem, Switzerland) was used as a positive control $(200 \mu \mathrm{M})$. Assays were performed under automated conditions (Fluent ${ }^{\circledR}$ 780, Tecan, Switzerland) equipped with a microplate reader (Infinite M1000 Pro, Tecan, Switzerland). Calculation of Z prime (Z') for validation was performed according to Zhang et al. ${ }^{66}$ and plates were considered valid for further analyses where Z' was >0.6. Data analysis was conducted using Prism 7.02 (GraphPad Software, USA).

Surface Plasmon Resonance Spectroscopy (SPR). Measurements were conducted on a flow based SPR instrument (Sierra spr-16, Bruker Daltonics, USA). E. coli ClpP was immobilized to an amino coupling chip at a concentration of $80 \mu \mathrm{g} / \mathrm{mL}$, in $10 \mathrm{mM}$ sodium acetate $\mathrm{pH} 4$, according to the manufacturer's protocols, with a buffer containing $150 \mathrm{mM} \mathrm{NaCl}, 10 \mathrm{mM}$ Hepes, $3 \mathrm{mM}$ EDTA and $0.05 \%(\mathrm{v} / \mathrm{v})$ Tween-20. The flow rate for protein immobilization was $10 \mu \mathrm{L} / \mathrm{min}$. The binding assay was performed in immobilization buffer with added DMSO (3.2\% (v/v) final) at a flow rate of $20 \mu \mathrm{L} / \mathrm{min}, 6 \mathrm{~min}$ injection and up to $300 \mathrm{~s}$ of dissociation time. The compounds were tested in a range of concentration between 2.5 and $320 \mu \mathrm{M}$. To compensate for non-specific interactions and solvent effects, signals were subjected to reference channel subtraction, DMSO and bulk-shift correction and further analyzed with Analyzer 3 (Bruker Daltonics, USA).

Cytotoxicity and cell-viability assays. Potential toxicity of the tested compounds was evaluated by ATP quantification using the CellTiter-Glo® viability assay kit (Promega, USA) and human cell lines A549, HepG2, HeLa. Cells were cultured in $95 \%$ air incubator at $5 \% \mathrm{CO}_{2}$ at $37^{\circ} \mathrm{C}\left(\right.$ Heracell $^{\mathrm{TM}} 240$, Thermo Fisher Scirntific, USA). The assays were performed in 96 white, flat bottom, sterile plates (\# 781073, Greiner Bio-One, Germany), with an assay volume of $20 \mu \mathrm{L}$. Cells were seeded at day zero at concentration of 2000 cells/well, except for A549 (500 cells/well), and placed in 95\% air incubator, 5\% $\mathrm{CO}_{2}$ at $37{ }^{\circ} \mathrm{C}$. After $24 \mathrm{~h}, 200 \mathrm{~nL}$ of test compounds were transferred into the plate using an Echo® 550 
1 liquid handler (Labcyte, USA), resulting in a final DMSO concentration of 1\%, and were further

2 incubated for $48 \mathrm{~h}$. Luminescence was quantified by EnVision plate reader (PerkinElmer, Germany) and compared to DMSO-treated cells. The compounds were tested in dose-response at 1:3 dilutions starting from $100 \mu \mathrm{M}$. DMSO (1\%) and valinomycin $(10 \mu \mathrm{M})$ were used as negative and positive controls respectively. Data analysis was conduced using Prism 7.02 (GraphPad Software, USA). Plates with Z'>0.5 were accepted.

Antibacterial assays. Compounds were tested for antimicrobial activity using seven different strains (Table S1, supporting information). All assays were conducted in 96-well, flat bottom, sterile plates (\#167008, Nunc, VWR, USA). $5 \mathrm{~mL}$ of fresh sterile saline solution was inoculated with a single colony from a Mueller Hinton Agar (MHA) plate of the bacteria strain (not older than $24 \mathrm{~h}$ ). Bacterial supension was adjusted to contain $1 \times 10^{6} \mathrm{CFU} / \mathrm{mL}$ in fresh sterile Mueller Hilton Broth (MHB) media. Compounds to be tested were transferred into the assay plate in triplicate for screening (at $100 \mu \mathrm{M}$ ), along with controls of $2 \%$ DMSO or ciprofloxacin (the latter employed at MIC concentration for each strain) and $100 \mu \mathrm{L}$ of the bacterial solution was added (final incolum $5 \times 10^{5} \mathrm{CFU} / \mathrm{mL}$ ). The final volume employed for the assay was $200 \mu \mathrm{L}$.

The absorbance at $600 \mathrm{~nm}$ was measured with the Multiskan GO plate reader (Thermo Fisher Scientific, Finland) or Varioskan LUX plate reader (Thermo Fisher Scientific, Finland) at time 0 and different time points and used for quantifying bacterial growth. Plates were incubated in a plate shaker (500 rpm) at $37{ }^{\circ} \mathrm{C}$ between the measurements.

Selected studies were conducted in the presence of an efflux pump substrate ( $25 \mu \mathrm{M}$ of Phe-Arg $\beta$ naphthylamide dihydrochloride (\#P4157, Sigma-Aldrich, USA) with Escherichia coli BW25-113 (wild type) and isogenic E.coli JW0427-1 ( $\Delta$ clpP $),{ }^{67}$ (derived from E. coli BW25-113).

Nitric oxide stress was induced by adding $2 \mathrm{mM}$ of DPTA NONOate ((Z)-1-[N-(3-aminopropyl)-N-(3ammoniopropyl)amino]diazen-1-ium-1,2-diolate, Cayman Chemical), dissolved in $\mathrm{NaOH}(0.14 \mathrm{mM}$ stock solution) in a $E$. coli $\mathrm{BW} 25-113$ culture at $\mathrm{OD}_{600}=0.1$ in $\mathrm{M} 9$ media supplemented with $10 \mathrm{mM}$ glucose. The bacterial culture was previously grown in MHB overnight, shaking at $250 \mathrm{rpm}$ at $37{ }^{\circ} \mathrm{C}$. On the experimental day, fresh M9 medium supplemented with $10 \mathrm{mM}$ glucose was inoculated at 1:100 ratio with the overnight culture and grown until approximately $\mathrm{OD}_{600}=0.3$. The assay was conducted 
1 at $37{ }^{\circ} \mathrm{C}$ while shaking $\left(500 \mathrm{rpm}\right.$ ), and the bacterial growth was monitored measuring the $\mathrm{OD}_{600}$ every

2 hour for 15 or $24 \mathrm{~h}$. The isogenic mutant E. coli JW0427-1 was used as control, an internal control or as strain study in a control experiment. The mutant was treated in the same way of the WT.

Molecular Docking. Molecular docking was performed using GOLD version 5.4.1 (Cambridge Crystallographic Data Centre, Cambridge, UK). Selection of the optimal scoring function was carried out by redocking the only co-crystallized non-covalently bound ClpP inhibitor AV145 (PDB ID 5DL1) into $S$. aureus ClpP. For newly identified inhibitors, the E. coli ClpP X-ray crystal structure 2FZS was selected. All protein structures were prepared with the molecular modeling software suite Molecular Operating Environment (MOE, Chemical Computing Group Inc., Montreal, Canada) version 2016.0802 and energy minimized using an Amber10:EHT force field with implicit solvation model (R-Field). Three-dimensional coordinates of ligands to be docked were generated within MOE. Redocking of cocrystallized AV145 into the ClpP structure 5DL1 (all 14 chains) revealed the scoring function GoldScore to be best suited for docking non-covalent compounds into ClpP, resulting in top-ranked docking poses with heavy atom root-mean-square deviation (RMSD) values $0.68 \AA$ for all 14 monomers. The search space for compounds to be docked into E. coli $\mathrm{ClpP}$ was defined by a sphere of 15 Å radius centered on atom C10 of the ligand. For each compound, 50 docking runs were conducted. The early termination option was switched off. The Asn150 amide side was allowed to flip by 180 degrees.

\section{ASSOCIATED CONTENT}

\section{Supporting Information}

The Supporting Information is available free of charge on the ACS Publications website:

-Detailed protocols, extended data series, additional charts and graphs for the in vitro HTS enzymatic assay and bacterial growth assays can be found in the associated content (PDF). -Molecular formula strings (CSV).

\section{AUTHOR INFORMATION}


1 *Corresponding Authors. E-mail: koen.augustyns@uantwerpen.be. Phone: +32 326527 17. Fax: +32

2326527 39. E-mail: bjoern.windshuegel@ime.fraunhofer.de. Phone: +49 (0) 40 303764-286. Fax: +49

$3 \quad(0) 40303764-100$.

$4{ }^{\S}$ Author Contributions. C.M.-C. ${ }^{1}$ and E.S. ${ }^{2}$ contributed equally to this study. The manuscript was

5 written with contributions of all authors. All authors gave approval to the final version of the 6 manuscript.

7 Funding. C.M.-C. ${ }^{1}$ and E.S. ${ }^{2}$ were financed by the MSCA-ITN-2014-ETN project INTEGRATE (grant 8 number 642620). C.D.C and P.T. were supported by the Academy of Finland Grants 277001 and 9 304697. H. B.-O. and L.R. received DFG funding (SFB 766 and GRK 1708).

\section{ACKNOWLEDGMENTS}

This research was supported by the MSCA-ITN-2014-ETN project INTEGRATE (grant number 642620). The Laboratory of Medicinal Chemistry is a partner of the Antwerp Drug Discovery Network (www.addn.be). C.D.C and P.T. thank the Academy of Finland (Grants no. 277001 and 304697) for financial support. We thank Dr. Peter Sass for providing the pETDclpPec construct.

\section{ABBREVIATIONS USED}

ADEPs

Acyldepsipeptides

Caseinolytic protease subunit A

Caseinolytic protease subunit $\mathrm{X}$

DIPEA

$N, N$-diisopropylethylamine

DPP8

Dipeptidyl peptidase 8

DPTA NONOate

(Z)-1-[N-(3-Aminopropyl)-N-(3-ammoniopropyl)amino]diazen-1-ium-1,2-

diolate

Escherichia coli

Kallikrein-related peptidase 4

Listeria monocytogenes 
1 MOE

2 S. aureus

3 SDS-PAGE

4 SPR

5 Suc-LY-AMC

6

7 UAMC

8 uPA

9 WT

10

11

12

13

14

15

16

17

18

19

20

21

22

23

24

25

26

27

\section{REFERENCES}

Molecular Operating Environment

Staphylococcus aureus

Sodium Dodecyl Sulphate - PolyAcrylamide Gel Electrophoresis

Surface Plasmon Resonance Spectroscopy

4-(((S)-1-(((S)-2-(4-Hydroxyphenyl)-1-(4-methyl-2-oxo-2H-chromen-7-

yl)ethyl)amino)-4-methyl-1-oxopentan-2-yl)amino)-4-oxobutanoic acid

University of Antwerp Medicinal Chemistry group

Urokinase plasminogen activator

Wild-type

Z prime

Benzyl ((S)-1-(((S)-4-chloro-1-(4-hydroxyphenyl)-3-oxobutan-2-yl)amino)-4-

methyl-1-oxopentan-2-yl)carbamate

Mutant defective in clpP

Mutant impaired in lipidA synthesis

Mutant defective in tolC

Nitric oxide

1. Bartlett, J. G.; Gilbert, D. N.; Spellberg, B., Seven ways to preserve the miracle of antibiotics. Clin. Infect. Dis. 2013, 56 (10), 1445-1450.

2. Chellat, M. F.; Raguz, L.; Riedl, R., Targeting antibiotic resistance. Angew. Chem. Int. Ed. Engl. 2016, 55 (23), 6600-6626.

3. Kupferschmidt, K., Resistance fighters. Science 2016, 352 (6287), 758-761.

4. WHO Antimicrobial Resistance: Global Report on Surveillance 2014; 2014.

5. Rossolini, G. M.; Arena, F.; Pecile, P.; Pollini, S., Update on the antibiotic resistance crisis. Curr. Opin. Pharmacol. 2014, 18, 56-60. 
1 6. Butler, M. S.; Blaskovich, M. A.; Cooper, M. A., Antibiotics in the clinical pipeline at the end 2 of 2015. J. Antibiot. 2017, 70 (1), 3-24.

$37 . \quad$ Goodreid, J. D.; Janetzko, J.; Santa Maria, J. P., Jr.; Wong, K. S.; Leung, E.; Eger, B. T.; 4 Bryson, S.; Pai, E. F.; Gray-Owen, S. D.; Walker, S.; Houry, W. A.; Batey, R. A., Development and 5 characterization of potent cyclic acyldepsipeptide analogues with increased antimicrobial activity. $J$. Med. Chem. 2016, 59 (2), 624-646.

$7 \quad$ 8. Brotz-Oesterhelt, H.; Sass, P., Bacterial caseinolytic proteases as novel targets for antibacterial 8 treatment. Int. J. Med. Microbiol. 2014, 304 (1), 23-30.

9 9. Frees, D.; Brondsted, L.; Ingmer, H., Bacterial proteases and virulence. Subcell. Biochem. 2013, $66,161-192$.

10. Arribas, J.; Castaño, J. G., A comparative study of the chymotrypsin-like activity of the rat liver multicatalytic proteinase and the ClpP from Escherichia coli. J. Biol. Chem. 1993, 268 (28), 2116521171.

11. Frees, D.; Sorensen, K.; Ingmer, H., Global virulence regulation in Staphylococcus aureus: pinpointing the roles of $\mathrm{ClpP}$ and $\mathrm{ClpX}$ in the sar/agr regulatory network. Infect. Immun. 2005, 73 (12), 8100-8108.

12. Gaillot, O.; Pellegrini, E.; Bregenholt, S.; Nair, S.; Berche, P., The ClpP serine protease is essential for the intracellular parasitism and virulence of Listeria monocytogenes. Mol. Microbiol. 2000, $35(6), 1286-1294$.

13. Gaillot, O.; Bregenholt, S.; Jaubert, F.; Di Santo, J. P.; Berche, P., Stress-induced ClpP serine protease of Listeria monocytogenes is essential for induction of listeriolysin O-dependent protective immunity. Infect Immun 2001, 69 (8), 4938-4943.

14. Kwon, H. Y.; Ogunniyi, A. D.; Choi, M. H.; Pyo, S. N.; Rhee, D. K.; Paton, J. C., The ClpP protease of Streptococcus pneumoniae modulates virulence gene expression and protects against fatal pneumococcal challenge. Infect. Immun. 2004, 72 (10), 5646-5653. 15. Park, C. Y.; Kim, E. H.; Choi, S. Y.; Tran, T. D.; Kim, I. H.; Kim, S. N.; Pyo, S.; Rhee, D. K., Virulence attenuation of Streptococcus pneumoniae clpP mutant by sensitivity to oxidative stress in macrophages via an NO-mediated pathway. J. Microbiol. 2010, 48 (2), 229-235. 
1 16. Robinson, J. L.; Brynildsen, M. P., An ensemble-guided approach identifies ClpP as a major

2 regulator of transcript levels in nitric oxide-stressed Escherichia coli. Metab. Eng. 2015, 31, 22-34.

3 17. Flynn, J. M.; Neher, S. B.; Kim, Y.-I.; Sauer, R. T.; Baker, T. A., Proteomic discovery of

4 cellular substrates

5 of the ClpXP protease reveals five

6 classes of ClpX-recognition signals. Mol. Cell 2003, 11, 671-683.

$7 \quad$ 18. Zhao, B. B.; Li, X. H.; Zeng, Y. L.; Lu, Y. J., ClpP-deletion impairs the virulence of Legionella 8 pneumophila and the optimal translocation of effector proteins. BMC Microbiol. 2016, 16 (1), 174.

9 19. Qiu, D.; Eisinger, V. M.; Head, N. E.; Pier, G. B.; Yu, H. D., ClpXP proteases positively regulate alginate overexpression and mucoid conversion in Pseudomonas aeruginosa. Microbiology 2008, 154, 2119-2130.

20. Alexopoulos, J. A.; Guarne, A.; Ortega, J., ClpP: a structurally dynamic protease regulated by AAA+ proteins. J. Struct. Biol. 2012, 179 (2), 202-210.

21. Ma, W.; Tang, C.; Lai, L., Specificity of trypsin and chymotrypsin: Loop-motion-controlled dynamic correlation as a determinant. Biophys. J. 2005, 89 (2), 1183-1193.

22. Schelin, J.; Lindmark, F.; Clarke, A. K., The ClpP multigene family for the ATP-dependent Clp protease in the cyanobacterium Synechococcus. Microbiology 2002, 148, 2255-2265.

23. Gur, E.; Ottofueling, R.; Dougan, D. A., Regulated Proteolysis in Microrganisms. 1 ed.; Springer Netherlands: 2013.

24. Olivares, A. O.; Baker, T. A.; Sauer, R. T., Mechanistic insights into bacterial AAA+ proteases and protein-remodelling machines. Nat. Rev. Microbiol. 2016, 14 (1), 33-44.

25. Brotz-Oesterhelt, H.; Beyer, D.; Kroll, H. P.; Endermann, R.; Ladel, C.; Schroeder, W.; Hinzen, B.; Raddatz, S.; Paulsen, H.; Henninger, K.; Bandow, J. E.; Sahl, H. G.; Labischinski, H., Dysregulation of bacterial proteolytic machinery by a new class of antibiotics. Nat. Med. 2005, 11 (10), 1082-1087. 26. Malik, I. T.; Brotz-Oesterhelt, H., Conformational control of the bacterial Clp protease by natural product antibiotics. Nat. Prod. Rep. 2017, 34 (7), 815-831. versatile bacterial. Angew. Chem., Int. Ed. 2008, 47 (24), 4600-4603. 
1 28. Bottcher, T.; Sieber, S. A., beta-Lactones as specific inhibitors of CIpP attenuate the production 2 of extracellular virulence factors of Staphylococcus aureus. J. Am. Chem. Soc. 2008, 130 (44), 1440014401.

29. Bottcher, T.; Sieber, S. A., beta-Lactones decrease the Intracellular virulence of Listeria monocytogenes in macrophages. Chemmedchem 2009, 4 (8), 1260-1263.

30. Bottcher, T.; Sieber, S. A., Structurally refined beta-lactones as potent inhibitors of devastating bacterial virulence factors. Chembiochem 2009, 10 (4), 663-666.

31. Hackl, M. W.; Lakemeyer, M.; Dahmen, M.; Glaser, M.; Pahl, A.; Lorenz-Baath, K.; Menzel, T.; Sievers, S.; Bottcher, T.; Antes, I.; Waldmann, H.; Sieber, S. A., Phenyl esters are potent inhibitors of caseinolytic protease $\mathrm{P}$ and reveal a stereogenic switch for deoligomerization. J. Am. Chem. Soc. 2015, 137 (26), 8475-8483.

32. Pahl, A.; Lakemeyer, M.; Vielberg, M. T.; Hackl, M. W.; Vomacka, J.; Korotkov, V. S.; Stein, M. L.; Fetzer, C.; Lorenz-Baath, K.; Richter, K.; Waldmann, H.; Groll, M.; Sieber, S. A., Reversible Inhibitors Arrest ClpP in a defined conformational state that can be revoked by $\mathrm{ClpX}$ association. Angew. Chem. Int. Ed. Engl. 2015, 54 (52), 15892-15899.

33. Moreira, W.; Ngan, G. J.; Low, J. L.; Poulsen, A.; Chia, B. C.; Ang, M. J.; Yap, A.; Fulwood, J.; Lakshmanan, U.; Lim, J.; Khoo, A. Y.; Flotow, H.; Hill, J.; Raju, R. M.; Rubin, E. J.; Dick, T., Target mechanism-based whole-cell screening identifies bortezomib as an inhibitor of caseinolytic protease in mycobacteria. mBio 2015, 6 (3), e00253-15.

34. Akopian, T.; Kandror, O.; Tsu, C.; Lai, J. H.; Wu, W. G.; Liu, Y. X.; Zhao, P.; Park, A.; Wolf, L.; Dick, L. R.; Rubin, E. J.; Bachovchin, W.; Goldberg, A. L., Cleavage specificity of Mycobacterium tuberculosis $\mathrm{ClpP} 1 \mathrm{P} 2$ protease and identification of novel peptide substrates and boronate inhibitors with anti-bacterial activity. J. Biol. Chem. 2015, 290 (17), 11008-11020.

35. Mundra, S.; Thakur, V.; Bello, A. M.; Rathore, S.; Asad, M.; Wei, L.; Yang, J.; Chakka, S. K.; Mahesh, R.; Malhotra, P.; Mohmmed, A.; Kotra, L. P., A novel class of Plasmodial ClpP protease inhibitors as potential antimalarial agents. Bioorg. Med. Chem. 2017, 25 (20), 5662-5677.

36. Szyk, A.; Maurizi, M. R., Crystal structure at 1.9A of E. coli ClpP with a peptide covalently bound at the active site. J. Struct. Biol. 2006, 156 (1), 165-174. 
$137 . \quad$ Lamden, L. A. B., P. A., Aminoalkylphosphonofluoridate derivatives: rapid and potentially

2 selective inactivators of serine peptidases. Biochem. Biophys. Res. Commun. 1983, 112 (3), 1085-1090.

3 38. Joossens, J.; Van der Veken, P.; Surpateanu, G.; Lambeir, A. M.; El-Sayed, I.; Ali, O. M.;

4 Augustyns, K.; Haemers, A., Diphenyl phosphonate inhibitors for the urokinase-type plasminogen

5 activator: Optimization of the P4 position. J. Med. Chem. 2006, 49 (19), 5785-5793.

6 39. Joossens, J.; Ali, O. M.; El-Sayed, I.; Surpateanu, G.; Van der Veken, P.; Lambeir, A. M.;

7 Setyono-Han, B.; Foekens, J. A.; Schneider, A.; Schmalix, W.; Haemers, A.; Augustyns, K., Small,

8 potent, and selective diaryl phosphonate inhibitors for urokinase-type plasminogen activator with in

$9 \quad$ vivo antimetastatic properties. J. Med. Chem. 2007, 50 (26), 6638-6646.

40. Van der Veken, P.; Soroka, A.; Brandt, I.; Chen, Y. S.; Maes, M. B.; Lambeir, A. M.; Chen,

X.; Haemers, A.; Scharpe, S.; Augustyns, K.; De Meester, I., Irreversible inhibition of dipeptidyl peptidase 8 by dipeptide-derived diaryl phosphonates. J. Med. Chem. 2007, 50 (23), 5568-5570.

41. Winiarski, L.; Oleksyszyn, J.; Sienczyk, M., Human neutrophil elastase phosphonic inhibitors with improved potency of action. J. Med. Chem. 2012, 55 (14), 6541-6553.

42. Pietrusewicz, E.; Sienczyk, M.; Oleksyszyn, J., Novel diphenyl esters of peptidyl alphaaminoalkylphosphonates as inhibitors of chymotrypsin and subtilisin. J. Enzyme Inhib. Med. Chem. 2009, 24 (6), 1229-1236.

43. Burchacka, E.; Skorenski, M.; Sienczyk, M.; Oleksyszyn, J., Phosphonic analogues of glutamic acid as irreversible inhibitors of Staphylococcus aureus endoproteinase GluC: An efficient synthesis and inhibition of the human IgG degradation. Bioorg. Med. Chem. Lett. 2013, 23 (5), 1412-1415. 44. Burchacka, E.; Zdzalik, M.; Niemczyk, J. S.; Pustelny, K.; Popowicz, G.; Wladyka, B.; Dubin, A.; Potempa, J.; Sienczyk, M.; Dubin, G.; Oleksyszyn, J., Development and binding characteristics of phosphonate inhibitors of SplA protease from Staphylococcus aureus. Protein Sci. 2014, 23 (2), 179189.

45. Dess, D. B.; Martin, J. C., Readily accessible 12-I-5 oxidant for the conversion of primary and secondary alcohols to aldehydes and ketones. J. Org. Chem. 1983, 48 (22), 4155-4156. 46. Van der Veken, P.; Sayed, I.; Joossens, J.; Stevens, C.; Augustyns, K.; Haemers, A., Lewis acid catalyzed synthesis of $N$-protected diphenyl 1-aminoalkylphosphonates. Synthesis 2005, 36, 634-638. 
1 47. Okano, K.; Okuyama, K. I.; Fukuyama, T.; Tokuyama, H., Mild debenzylation of aryl benzyl 2 ether with $\mathrm{BCl}(3)$ in the presence of pentamethylbenzene as a non-Lewis-basic cation scavenger. Synlett 2008, (13), 1977-1980.

48. Van Soom, J.; Crucitti, G. C.; Gladysz, R.; Van der Veken, P.; Di Santo, R.; Stuyver, I.; Buck, V.; Lambeir, A. M.; Magdolen, V.; Joossens, J.; Augustyns, K., The first potent diphenyl phosphonate KLK4 inhibitors with unexpected binding kinetics. MedChemComm 2015, 6 (11), 1954-1958.

49. Oleksyszyn, J. S., L.; Mastalerz, P., Diphenyl 1-aminoalkanephosphonates. Synthesis 1979, 12, 985-986.

50. Powers, J. C.; Boduszek, B.; Oleksyszyn, J. Basic $\alpha$-Aminoalkylphosphonate Derivatives. US $5686419,1997$.

51. Mazur, R. H. N-Adamantane-Substituted Tetrapeptide Amides. US4273704A, 1981.

52. Grundl, M.; Oost, T.; Pautsch, A.; Peters, S.; Riether, D.; Wienen, W. Substituted N-[1-Cyano2-(phenyl)ethyl]-2-azabicyclo[2.2.1]heptane-3-carboxamide Inhibitors of Cathepsin C. WO 2013041497, 2013.

53. Augustyns, K. J., J.; Van, D. V. P.; Lambeir, A. M. V. R.; Scharpe, S.; Haemers, A. Novel Urokinase Inhibitors. WO2007045496, 2007.

54. Augustyns, K. J., J.; Lambeir, A. M.; Messaggie, J.; Van der Veken, P. Activity-Based Probes for the Urokinase Plasminogen Activator. WO2012152807, 2012.

55. Joossens, J.; Augustyns, K.; Lambeir, A. M.; Van der Veken, P.; Van Soom, J.; Magdolen, V. Novel KLK4 inhibitors. WO2015144933 A1, 2015.

56. Burchacka, E.; Sienczyk, M.; Frick, I. M.; Wysocka, M.; Lesner, A.; Oleksyszyn, J., Substrate profiling of Finegoldia magna SufA protease, inhibitor screening and application to prevent human fibrinogen degradation and bacteria growth in vitro. Biochimie 2014, 103, 137-143.

57. Boduszek, B., Synthesis of novel phosphonopeptides derived from pyridylmethylphosphonate diphenyl esters. Phosphorus, Sulfur Silicon Relat. Elem. 2001, 176 (1), 119-124.

58. Sienczyk, M.; Oleksyszyn, J., A convenient synthesis of new $\alpha$-aminoalkylphosphonates, aromatic analogues of arginine as inhibitors of trypsin-like enzymes. Tetrahedron Lett. 2004, 45 (39), 7251-7254. 
1 59. Lejczak, B.; Kafarski, P.; Soroka, M.; Mastalerz, P., Synthesis of the phosphonic acid analog

2 of serine. Synthesis 1984, 7, 577-580.

3 60. Ali, O. M., Design and synthesis of small and potent inhibitors of urokinase as antitumor agents.

$4 \quad$ World J. Chem. 2012, 7 (1), 01-06.

5 61. Sienczyk, M.; Lesner, A.; Wysocka, M.; Legowska, A.; Pietrusewicz, E.; Rolka, K.;

6 Oleksyszyn, J., New potent cathepsin G phosphonate inhibitors. Bioorg. Med. Chem. 2008, 16 (19), $7 \quad 8863-8867$.

8 62. Oleksyszyn, J.; Marcinkowska, A.; Sieńczyk, M.; Drąg-Zalesińska, M.; Wysocka, T. 9 Application of Aromatic Amidines and Guanidines, Derivatives of Diphenyl Esters of 1Aminoalkanephosphonic Acids for Induction of Apoptosis of Cancer Cells. PL 213133, 2013. 63. Yang, D.; Fan, L.; Su, X.; Wang, C.; Li, H.; Wang, L.; Zhang, K. Preparation of L-(mAminophenyl)glycine and its Derivatives. CN 101633626 A, 2010. 64. Andrew, R. G.; Barker, A. J.; Boyle, F. T.; Wardleworth, J. M. Anti-Tumor Compounds. US5280027, 1994. 65. Sass, P.; Bierbaum, G., Lytic activity of recombinant bacteriophage phi11 and phi12 endolysins on whole cells and biofilms of Staphylococcus aureus. Appl Environ Microbiol 2007, 73 (1), 347-352. 66. Zhang, J.-H.; Chung, T. D. Y., A simple statistical parameter for use in evaluation and validation of high throughput screening assays. J. Biomol. Screening 1999, 4 (2), 67-73. 67. Baba, T.; Ara, T.; Hasegawa, M.; Takai, Y.; Okumura, Y.; Baba, M.; Datsenko, K. A.; Tomita, M.; Wanner, B. L.; Mori, H., Construction of Escherichia coli K-12 in-frame, single-gene knockout mutants: the Keio collection. Mol. Syst. Biol. 2006, 2, 2006.0008. 
1 Table of Contents Graphic
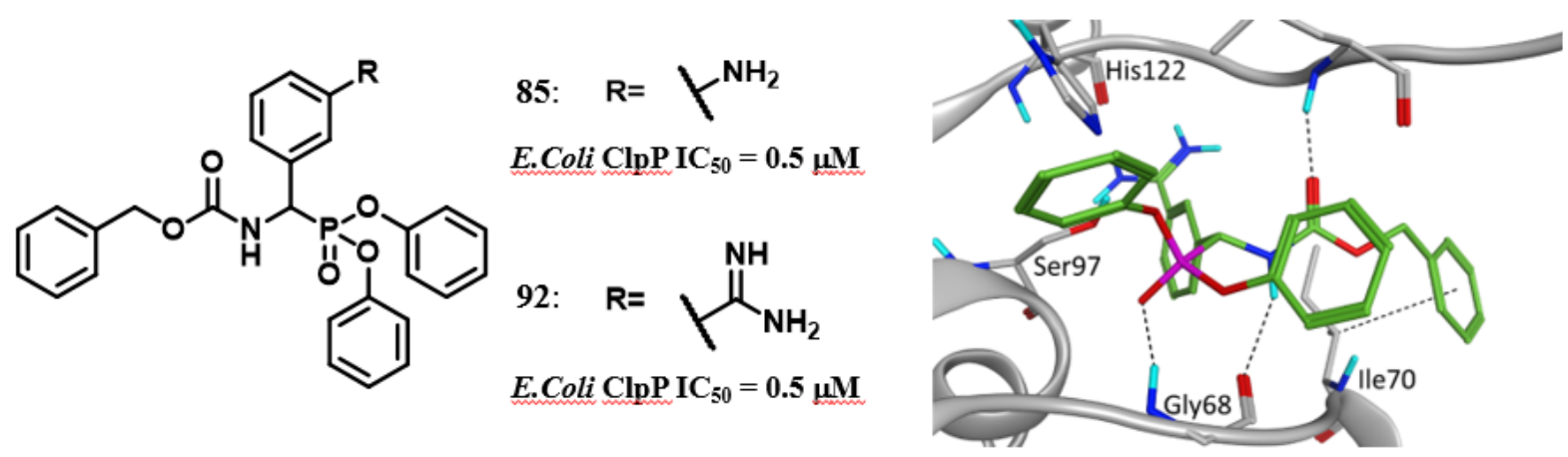